\title{
ARTICLES
}

\section{RED LIGHTS TO GREEN LIGHTS: FROM 20TH CENTURY ENVIRONMENTAL REGULATION TO 21ST CENTURY SUSTAINABILITY}

\author{
$\mathrm{BY}$ \\ DANIEL C. ESTY*
}

\begin{abstract}
Twentieth century environmental protection delivered significant improvements in America's air and water quality and led companies to manage their waste, use of toxic substances, and other environmental impacts with much greater care. But the pace of environmental progress has slowed as the limits of the command-and-control regulatory model have been reached. This Article calls for a new 21st century sustainability strategy that overcomes the ideological, structural, and operational issues that have led to political gridlock and blocked environmental policy reform. It makes the case for a transformed legal framework that prioritizes innovation, requires payment of "harm charges" and an "end to externalities," and shifts toward market-based regulatory strategies that expand business and individual choices rather than government mandates. It further proposes a systems approach to policy that acknowledges tradeoffs across competing aims, integrates economic and energy goals with environmental aspirations, and emphasizes on-the-ground pollution control and natural resource management results. This new approach would go beyond the "red lights" and stop signs of the existing framework of environmental law that centers on telling people what
\end{abstract}

\footnotetext{
* Hillhouse Professor of Environmental Law and Policy, Yale University. Thanks to Quentin Karpilow for research assistance and to Whitney Leonard, Yume Hoshijima, Paul Anastas, Ken Gillingham, Ben Cashore, Bruce Ackerman, William Reilly, and Gordon Binder for comments on earlier drafts. Many thanks as well for the feedback from participants in the Yale Law School Faculty Seminar and the Lewis \& Clark Law School Distinguished Visitor Lecture as well as presentations of earlier drafts at Arizona State University Law School and Pace Law School.
} 
they cannot do, to a broader structure of incentives and "green lights" that would engage the public and the business world in environmental problem solving. Building on the changed circumstances of the 21st century, including the extensive breakthroughs in information and communications technologies, the transformation envisioned would permit a shift in the "environmental possibility frontier" and a lighter and stronger structure of pollution control and resource management that could appeal to Americans from all parts of the political spectrum, making real reform possible after decades of deadlock.

I. INTRODUCTION ..................................................................... 3

II. WHAT DERAILED THE 20TH CENTURY APPROACH TO ENVIRONMENTAL PROTECTION?................................................... 6

A. Political Rupture.............................................................. 7

B. Structural Failure.............................................................. 9

C. Operational Shortcomings............................................. 16

III. CORE PRINCIPLES FOR 21ST CENTURY SUSTAINABILITY................. 24

A. The End of Externalities.................................................. 24

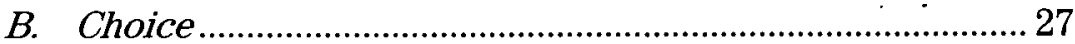

C. Interdependence and Integration: Systems Thinking ....... 29

D. Innovation and Green Lights............................................. 31

IV. GOVERNANCE FOR A 21ST CENTURY SUSTAINABILITY STRATEGY............................................................................. 34

A. Going Beyond Government-Centered Environmental

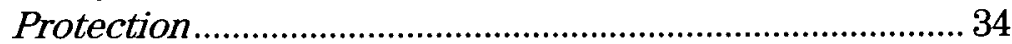

B. Integration: Toward a Systems Approach to Environmental Issues........................................................ 37

C. Reinvigorated Environmental Federalism....................... 40

V. RESETTING THE 21ST CENTURY ENVIRONMENTAL POSSIBILITY

FRONTIER .......................................................................... 43

A. Advances in Information and Communications Technologies................................................................... 43

1. Big Data............................................................... 44

2. Internet and Communications Breakthroughs............. 51

3. Transparency.............................................................. 54

B. Science and Knowledge............................................. 58

C. Changed Role of Government........................................ 58

D. Business Leadership........................................................ 64

E. Changed Roles of Individuals..........................................66

F. Nongovernmental Organizations and other

G. Focus on Finance ......................................................... 71

H. Economic Transition and Slower Growth....................... 76

I. Planetary Boundaries...................................................... 77

VI. CONCLUSION ............................................................... 79 


\section{INTRODUCTION}

Environmental protection has gone from a realm of broad political consensus in the 1970s to a domain of bitter partisan battles today. As a result, virtually no substantial environmental legislation has moved through Congress in a generation. This gridlock in Washington has stalled efforts to recast our pollution control programs to meet evolving challenges such as climate change, restructure our regulatory toolbox to take advantage of 21st century policy opportunities (notably the advances in information technologies), reframe the country's energy strategy, and advance new approaches to land conservation.

This Article begins with two related questions: Why has environmental progress in America come to a dead stop? What will it take to get political consensus on how to go forward? In answering these two questions, I highlight the need to move from our existing 20th century model of environmental regulation to a new 21 st century sustainability strategy ${ }^{1}$ that builds on the successes of the past five decades, but acknowledges both that our current circumstances and looming challenges have changed. I argue that the federal-government-led structure of command-and-control mandates worked reasonably well in the 1970s as America launched efforts to address critical concerns about air pollution, water quality, chemical exposure, and land use. But what worked in those early days is no longer our best path forward. Going beyond the usual academic critique of environmental law and policy theory, I highlight the political obstacles that have made systematic reforms of our environmental protection regime impossible to advance. I argue that progress depends on a transformed agenda that addresses both the revealed weaknesses of the current legal framework and the need for a reframed political consensus about energy and the environment.

We've come a long way since Earth Day 1970, which might be seen as the launch of the modern era of environmental law and policy. We've learned a great deal about the spectrum of harms we face; the fate and transport of pollutants; the epidemiological and ecological impacts of emissions; and the environmental effects of choices made in other domains including energy, agriculture, trade, transportation, and the economy. We've come down a long learning curve and now have much more data and analysis about these problems, their causes, the interactions among pollutants, aggregate impacts

1 I argue for a "sustainability" focus that derives from the Brundtland Commission's definition of "sustainable development"-going beyond the "environment" to encompass intertwined social and economic issues and recognizing the need to address these concerns in a manner that acknowledges their interconnections and the reality of tradeoffs between and among them-as well as the need for optimization across them both in the short run and on an intergenerational time scale. WORLD COMM'N ON ENV'T \& DEV., OUR COMMON FUTURE 43-46 (1987). 
across various scales and over time, and what policy interventions work best in response.

Like a fast-growing teenager bursting out of children's clothes, our society plainly needs an updated approach to environmental protection for the 21 st century. Instead, we are stuck with an outdated regulatory model that no longer fits our current requirements and circumstances. Despite the widespread dissatisfaction with the status quo-from both the Left and the Right-and even some agreement on better ways of doing environmental protection, we have not seen major policy refinements or progress.

Change is never easy, especially within a fraught political context, but it is essential. Indeed, one of the most significant findings in social science of recent decades is the importance of innovation to healthy organizations. ${ }^{2}$ Businesses have come to learn that they must constantly remake themselves to stay competitive and profitable. ${ }^{3}$ Other institutions must similarly transform themselves to stay relevant and vibrant. Some parts of our administrate state have been remade for the 21st century. Recast telecommunications regulations helped to usher in the smartphone era. Regulatory reform also transformed the airline industry, railroads, and other sectors of society. ${ }^{5}$ The environmental arena and related energy systems have remained, however, curiously unchanged for decades. ${ }^{6}$ And, even when the broader political climate seems poised to support new policy directions, the structure of American democracy-which positions an engaged minority to obstruct majority action-makes meaningful change difficult unless a bipartisan transformation agenda can be forged.

I make the case in this Article for a reconfigured legal framework that can deliver real transformation because it takes up the opportunities to create a 21st century approach to energy and environmental challenges, and takes seriously the political necessity of a degree of consensus on the path forward. In laying out a possible new sustainability strategy, this Article proceeds in five parts. Part $\Pi$ provides a high-level analysis of the sources of

2 See generally Clayton M. Christensen, The InNovatoR's DILEMma: When New TEChNologies Cause Great Firms to Fail (1997); Clayton M. Christensen \& Michael Overdorf, Meeting the Challenge of Disruptive Change, HARV. Bus. REv., Mar.-Apr. 2000, at 66; John P. Kotter, Accelerate!, HARV. Bus. Rev., Nov. 2012, at 44; Gary P. Pisano, You Need an Innovation Strategy, HARV. BuS. REv., June 2015, at 44.

3 Mark W. Johnson, Clayton M. Christensen \& Henning Kagermann, Reinventing Your Business Model, Harv. Bus. REv., Dec. 2008, at 51, 52; Michael E. Porter, How Competitive Forces Shape Strategy, 57 HARV. Bus. REV., Mar.-Apr. 1979, at 137, 144.

4 Reed Hundt, Wireless: The Common Medium of Conversation, 20 MEDIA L. \& POL'Y 95, 97 (2011) (describing Federal Communication Commission's regulations that helped create a robust competitive market for wireless).

5 Clifford Winston, U.S. Industry Adjustment to Economic Deregulation, J. ECON. PERSP., Summer 1998, at 89, 101 tbl.3 (showing improvements in consumer welfare as a result of deregulation in the airlines, trucking, railroad, banking, and natural gas industries).

6 David W. Case, The Lost Generation: Environmental Regulatory Reform in the Era of Congressional Abdication, 25 DukE ENVTL. L. \& POL'Y F. 49, 50-51 (2014); see also Jody Freeman \& David B. Spence, Old Statutes, New Problems, 163 U. PA. L. REv. 1, 10 (2014) ("Since the mid1990s, EPA and FERC have continued to confront new and important environmental and energy challenges, but Congress has been largely absent from the policy response."). 
gridlock in America's environmental policy, highlighting the ideological, structural, and operational issues that have led to political breakdown and declining effectiveness of the 20th century environmental regulation model. It ends with a call for a new political theory of environmental protection around which Democrats and Republicans might find common groundmaking reform possible.

Part III spells out the core elements of a refined political theory of environmental protection to undergird a recast sustainability strategy building on: 1) a commitment to the "end of externalities" in keeping with the common law property rights, meaning that polluters ${ }^{7}$ must either stop their polluting activities or pay "harm charges" for their emissions; 2) an emphasis on choice rather than government mandates so as to provide both businesses and individuals greater flexibility in where to draw the line between stopping their harm-causing activities and paying for them; 3) an integrated or systems approach to environmental protection that recognizes interconnections across issues and the reality of tradeoffs among them; 4) a priority on innovation and the capacity to bring new technologies, information, and learning to bear in support of environmental protection and a transition to clean energy; and 5) a focus on "on-the-ground results," policy implementation, and improved outcomes over time.

Part IV translates these principles into a revised environmental governance structure. It calls for an environmental strategy that is broader than the 20th century government-centered (largely federal) regulatory model. I argue, in particular, for a sustainability strategy that goes beyond "red lights" that tell polluters what they cannot do, and creates an expanded structure of "green lights"-incentives to spur fresh thinking and creative responses to persistent pollution challenges. More fundamentally, I suggest that government is not the only actor able to deliver environmental progress-and in many circumstances not even the best-positioned driver of improved outcomes.

This vision requires a shift from a command-and-control regulatory strategy to one centrally focused on price signals that fully internalize externalities and offer marketplace rewards for those delivering breakthroughs. Change at the scale and speed required to deliver a sustainable future can be realized only by engaging the private sector and others positioned to invest in renewable power, energy efficiency, clean technologies, and the remaking of our homes, businesses, transportation systems, land use strategies, food production, and industrial infrastructure.

I further suggest that the locus of environmental decision making be redistributed based on the extent of the issue at hand and the externalities involved in different environmental challenges. Such a "matching principle"

7 Likewise, those consuming shared resources must either pay for this use or cease their consumption.

8 Henry N. Butler \& John R. Macey, Externalities and the Matching Principle: The Case for Reallocating Environmental Regulatory Authority, 14 YALE L. \& POL'Y REV. 23, 25 (1996) (arguing for a reallocation of environmental regulatory authority in accordance with the matching principle). 
would spread primary governance responsibilities from the global to the local scales-and move some number of decisions out of the realm of "governance" altogether, leaving choices up to the households or individuals affected. In practice, it would mean a reinvigorated commitment to environmental federalism that decentralizes pollution control and resource management to the greatest extent possible consistent with the "end of externalities" principle, thus promoting accountability and emphasizing results-oriented implementation. As I explain in detail below, a robust sustainability strategy would also benefit from some degree of cooperation and competition along both horizontal lines-across agencies and institutions at whatever governance level is primary-and verticallyinviting interaction among local, state, regional, national, and global entities.

Part V highlights a series of new realities in the 21 st century that shift the "environmental possibility frontier" but also change the foundations and assumptions on which a new approach to environmental issues must be built.

In Part VI, I conclude with some observations about the challenges that must be addressed as we develop a 21 st century sustainability strategy that can overcome the political, structural, and operational deficiencies of our current approach to environmental protection. ${ }^{8}$ I emphasize, in particular, that policy reform cannot proceed without political reframing and vice versa.

\section{WHAT DERAILED THE 20TH CENTURY APPROACH TO ENVIRONMENTAL PROTECTION?}

Today's environmental gridlock can be traced to a number of underlying causes. In this Part, I identify a set of political, structural, and operational issues that have led to the policy "freeze" of the past several decades. ${ }^{10} \mathrm{I}$ also lay out a possible foundation for the political consensus that would need to emerge to undertake transformative change in the energy and environmental arena.

9 Importantly, this Article outlines a longer-term agenda that is not tied to any particular U.S. administration. That said, I suspect that some of the proposals found in this essay-such as increased engagement with the business community on environmental issues - could gain traction during a Trump presidency. Moreover, while this agenda is written in the context of American law and history, the principles articulated here could have useful applications at the subnational level (e.g., California) and for foreign countries (e.g., China).

10 While I argue that environmental policymaking has slowed in recent years, it is important to recognize and celebrate the resiliency of environmentalism in the United States. As documented by Richard Lazarus, environmental law has persisted despite a number of policy efforts to undermine or dismantle it. RICHARD J. LAZARUS, THE MAKING OF ENVIRONMENTAL LAW, at xii (2004). 


\section{A. Political Rupture}

The trend over the past two decades toward ever-deeper partisanship in Congress has spilled over into energy and environmental debates. ${ }^{11}$ Likewise, with the loss of civility and erosion of the commitment to a spirit of compromise in support of the national interest that marked deliberations in both the House and Senate in the past, it has become ever harder to find middle ground political outcomes. ${ }^{12}$ The rapidly rising scale and overriding importance of money in election campaigns has further sharpened political divisions. $^{13}$ The huge investments made by special interests in campaign contributions tend to harden positions as the funders and their lobbyists insist that their narrowly defined goals be advanced or preserved. ${ }^{14}$

But the underlying rupture should be considered philosophical or ideological. In fact, while many commentators highlight divergent views about the seriousness of environmental problems, such as the highly visible disputes over climate change science, ${ }^{15} \mathrm{I}$ think the real divide is much less over the scope and seriousness of the problems ${ }^{16}$-and much more related to

11 Carol A. Casazza Herman, David Schoenbrod, Richard B. Stewart \& Katrina M. Wyman, Breaking the Logjam: Environmental Reform for the New Congress and Administration, 17 N.Y.U. ENVTL. L.J. 1, 1 (2008) ("For almost 20 years, political polarization and a lack of leadership have left environmental protection in the United States burdened with obsolescent statutes and regulatory strategies.”); Charles Shipan \& William Lowry, Environmental Policy and Party Divergence in Congress, 54 POL. REs. Q. 245, 251 (2001) (showing that congressional voting on environmental issues has diverged noticeably along party lines since 1970).

12 E.J. DIONNE JR., OUR DIVIDED POLITICAL HEART: THE BATTLE FOR THE AMERICAN IDEA IN AN AGE OF DISCONTENT 4 (2012) ("The consensus that guided our politics through nearly all of the twentieth century is broken. In the absence of a new consensus, we will continue to fight--and to founder."); Case, supra note 6, at 51 ("[T] he political consensus necessary for enactment of statutory authority for new or expanded mandatory regulatory programs to achieve desired environmental outcomes has been impossible to obtain."); Richard J. Lazarus, Congressional Descent: The Demise of Deliberative Democracy in Environmental Law, 94 GEO. L.J. 619, 622 (2006) ("Now, Congress passes almost no coherent, comprehensive environmental legislation and displays no ability to deliberate openly and systematically in response to changing circumstances and new information.").

13 Thomas E. ManN \& ANTHONY CoRrado, BRookings Inst., Party Polarization and CAMPAIGN FINANCE 1 (2014) ("Ideologically-based outside groups financed by wealthy donors appear to be sharpening partisan differences and resisting efforts to forge agreement across parties.").

14 Raymond J. La Raja, Campaign Finance and Partisan Polarization in the United States Congress, 9 DUKE J. CONST. L. \& PUB. POL'Y 223, 224 (2014) (arguing that political polarization has stemmed, in part, from the "most ideological elements in both parties [accruing] significant power from American campaign finance laws ...").

15 Hervé Le Treut et al., Historical Overview of Climate Change Science, in Climate Change 2007: The Physical ScIEnce Basis 95, 95 (Susan Solomon et al. eds., 2007) (reviewing the history of climate change science); Anthony A Leiserowitz et al, Climategate, Public Opinion, and the Loss of Trust, 57 AM. BEHAV. SCIENTIST 818, 819 (2013) (describing Climategate, the 2009 release of more than 1,000 confidential emails from of climate scientists, some of which suggested possible manipulation of climate change results).

16 Jody Freeman \& Andrew Guzman, Climate Change and U.S. Interests, 109 COLuM. L. REv. 1531, 1532 (2009) (observing that, while there is "a widespread though not universal consensus in the United States that climate change is real, that it is primarily the result of human activity, and that it poses a serious global threat," and "a consensus on the appropriate U.S. response ... 
the nature and impact of proposed solutions. ${ }^{17}$ Many Republicans have become convinced that the Democrats' (and environmental community's) answer to every problem involves Big Government mandates, intrusions on personal (and business) freedom of choice, and unjustified regulatory burdens. ${ }^{18}$ Thus, they prefer inaction to further regulatory burden. ${ }^{19}$

Many Democrats and their political allies, moreover, don't take Republican liberty concerns seriously. Nor do they worry very much about the cost of regulation, perhaps dismissing such concerns as overblown or justified by the bad behavior of corporations. ${ }^{20}$ They have become convinced that what Republicans really want is deregulation and an opportunity to advance the narrow economic interests of their business constituencies. ${ }^{21}$

This political landscape presents a seemingly intractable divide. If environmental reform requires Republicans to walk away from their fundamental commitments to smaller government and liberty as core public values, there can be no conversation. Likewise, if the agenda is simply deregulation, the Democrats will not be interested and will block reform

remains elusive"). Of course, the specific benefit-cost structure of climate change-with the costs borne immediately and the benefits spread globally and out over decades-makes it an issue of particular political difficulty. Kelly Levine et al., Overcoming the Tragedy of Super Wicked Problems: Constraining Our Future Selves to Ameliorate Global Climate, 45 POL'Y SCI. 123, 124 (2012); see also Michael P. Vandenbergh, Reconceptualizing the Future of Environmental Law: The Role of Private Climate Governance, 32 PACE ENVTL. L. REv. 382, 38485 (2015) [hereinafter Vandenbergh, Reconceptualizing] ( $[\mathrm{N}] \mathrm{o}$ environmental threat addressed by the statutory framework erected in 1970-1990 matches climate change in the magnitude and irreversibility of the potential harm, the cost of the response, the global scale, the deep integration of environmental harms and economic activity, and the justice concerns between developed and developing countries and between current and future generations."). That said, some have cautioned against presenting climate change as a unique societal problem, noting that global warming shares similar features to a variety of other complex societal problems. See Oren Cass, How to Worry about Climate Change, NAT'L AFF., Winter 2017, at 115, 130-31.

17 See Dan Kahan, Opinion, Fixing the Communications Failure, 463 NATURE 296, 296-97 (arguing that people's cultural beliefs impact their views of societal risks, such as climate change); Dan M. Kahan et al., The Polarizing Impact of Science Literacy and Numeracy on Perceived Climate Change Risks, 2 NATuRe Climate Change 732, 733-34 (finding that cultural polarization, rather than science literacy, best explains concern about climate change).

18 See, e.g., Timothy Cama, Conservative Groups Target Ozone Law in Puṣh for Rule's Rollback, HILL (May 9, 2016), https://perma.cc/VZ5F-PEU2 (describing pushback by conservatives against President Obama's new ozone pollution rule).

19 REPUBLICAN NAT'L COMM., REPUBLICAN PLATFORM 2016, at 21 (2016), https://perma.cc/ RJ95-LQRU (arguing for less environmental regulation on the grounds that environmental quality is already improving).

20 Joseph E. Aldy, Willingness to Pay and Political Support for a US National Clean Energy Standard, 2 NATURE Climate CHANGE 596, 597 (survey results showing that Democrats are willing to pay more than Republicans for a national clean energy standard); How Americans View the Top Energy and Environmental Issues, PEW RES. CTR. (Jan 15, 2015), https://perma.cc/K5WN-SLP9 (poll showing 71\% Democrats, but only $37 \%$ of Republicans, believe that stricter environmental laws are worth the costs).

21 See, e.g., Michael McAuliff \& Lucia Graves, War on the EPA: Republican Bills Would Erase Decades of Protection, HuFFINGTON POST (Oct. 9, 2011), https://perma.cc/W2PK-6RSZ (describing Democrats' responses to House Republican efforts to roll back environmental regulations-and the capacity of the minority to block change) 
efforts. ${ }^{22}$ But this need not be the choice. Progress, instead, will require a new political theory of environmental protection that acknowledges both a) the Democrats' call for more action where the science makes clear that important pollution or resource management problems persist, and b) the Republicans' philosophical concern with expanded and expensive government mandates.

What is needed is a recast environmental protection framework that is simultaneously stronger and lighter, integrating environmental and economic (and social) concerns, and using a policy toolkit that goes beyond command-and-control regulation. As I describe in more detail in Part III, a re-envisioned approach to environmental protection might also provide a foundation for the political reconciliation that must be achieved if policy reform is to proceed. To reiterate, in the face of the current political rupture, transformative change cannot be delivered by one party acting alone. Thus, for a new sustainability strategy to emerge, as much attention needs to be paid to the political economy of environmental reform as to the policy framework. ${ }^{23}$

\section{B. Structural Failure}

The second set of problems are structural and derive from several foundational elements of our existing environmental framework. This framework followed the civil rights model of "super statutes" ${ }^{\text {"4 }}$ that define broad standards ${ }^{25}$-really, moral claims - that are then implemented through a series of test cases. ${ }^{26}$ Our 1970 s environmental laws set out simple and sweeping goals, ${ }^{27}$ such as the declared purpose of the Clean Air Act, ${ }^{28}$ which

22 See, e.g., id; Leslie Kaufman, Push in States to Deregulate Environment, N.Y. TimES, Apr. 16,2011 , at A1. (describing Democrat-Republican clashes over environmental regulation at the state level).

23 Indeed, as Jonathan Gilligan and Michael Vandenbergh persuasively argue, political economy considerations often shapes which policy instrument will be optimal for addressing a particular pollution problem because any instrument's efficiency can depend critically on timing. For example, postponing climate action until the politics allow for a carbon charge may be suboptimal to other forms of more politically palatable (but perhaps "second best") climate instruments. The reasons for this calculus stem from the irreversibility of climate change, the risks of carbon dioxide tipping points, and the slow turnover of energy capital. See Jonathan M. Gilligan \& Michael P. Vandenbergh, Accounting for Political Feasibility in Climate Instrument Choice, 32 VA. ENVTL L.J. 1, 13-17 (2014).

24 William N. Eskridge, Jr. \& John Ferejohn, Super-Statutes, 50 DukE L.J. 1215, 1225-26 (2001).

25 James Gustave Speth, Distinguished Senior Fellow, Demos \& Professor of Law, Vt. Law Sch., A New American Environmentalism and the New Economy, Tenth Annual John H. Chafee Memorial Lecture on Science and the Environment at the National Conference on Science, Policy and the Environment 8 (Jan. 21, 2010), https://perma.cc/DR6W-KSYU (describing the ambition and breadth of the Clean Water Act and Clean Air Act).

26 James Gustave Speth, ANGELS BY THE RIVER: A MEMOIR (2014).

27 Richard J. Lazarus, Environmental Law at the Crossroads: Looking Back 25, Looking Forward 25, 2 MicH. J. ENVTL. \& ADMIN. L. 267, 269 (2013) (describing the environmental laws from the 1970 s as "revolutionary ... in their aspiration and potential reach").

2842 U.S.C. $\$ \S 7401-7671 q$ (2012). 
was "to protect and enhance the quality of the Nation's air resources so as to promote the public health and welfare. ${ }^{{ }^{29}}$ At the time this standard was set, killer smogs had caused twenty deaths near Pittsburgh ${ }^{30}$ and forced schools to shut down in Los Angeles. ${ }^{31}$ As such, getting the policy directionally correct seemed sufficient. Almost any kind and any degree of pollution control represented a positive, welfare-enhancing move. The benefits of taking action were so obvious that the possibility of overshooting and pushing environmental protection to the point where costs exceeded benefits was unimaginable.

In a similar vein, a number of our foundational environmental laws direct the United States Environmental Protection Agency (EPA) to protect public health with "an ample margin of safety" and without regard to costs. ${ }^{32}$ From this backdrop emerged our present regime of nationally determined (largely) uniform standards, which are translated into mandates that industry adopt best available technologies for pollution control. ${ }^{33}$ This command-and-control structure worked well in the early days of our modern environmental era when EPA was young and there were no pollution control models to follow, limited environmental science and data upon which to build policies, and no embedded societal ethos of commitment to environmental goals, especially in the business world. ${ }^{34}$

But fifty years later, much has changed. Environmental values are widely shared, ${ }^{35}$ in part because of the successes of these early

29 Id. $\S 7401(\mathrm{~b})(1)$.

30 Ann Murray, Smog Deaths in 1948 Led to Clean Air Laws, NAT'L PUB. RADIo (Apr. 22, 2009), https://perma.cc/WG32-7Y6G.

31 Lauren Raab, How Bad Was L.A.'s Smog When Barack Obama Went to College Here?, L.A. Times (Aug. 3, 2015), https://perma.cc/8FFF-6NK6.

32 See, e.g., Federal Water Pollution Control Act, 33 U.S.C. § 1317(a) (2012); Clean Air Act, 42 U.S.C. $\$ 7409$ (b) (2012).

33 See, e.g., id. $\S 7475(\mathrm{a})(4)$.

34 Daniel H. Cole \& Peter Z. Grossman, When is Command-and-Control Efficient? Institutions, Technology, and the Comparative Efficiency of Alternative Regulatory Regimes for Environmental Protection, 1999 WIS. L. REV. 887, 914 (1999) (“'TT]he early heavy reliance on command-and-control [in federal air pollution control efforts] have generally been nominally, if not optimally, efficient."); Herman, Schoenbrod, Stewart \& Wyman, supra note 11, at 4-5 (2008) ("The first wave of federal environmental regulation was aimed at addressing easily understood gross insults to the environment-smog filled urban air, flammable rivers, uncontrolled smoke stacks, and discharge pipes. Hierarchical command and control regulatory approaches were generally well-suited to addressing such problems. But these approaches now need to be augmented with additional regulatory tools to address a number of environmental problems that have proven intractable to hierarchical regulation (such as non-point water pollution) and new problems that have yet to be tackled (such as climate change)."); Michael T. Maloney \& Bruce Yandle, Estimation of the Costs of Air Pollution Control Regulation, 11 J. ENVTL. ECON. \& MGMT. 244, 246 (1984) ("[W]hen information costs are considered, one might argue that the development of clean air regulation since 1970 has actually been the best possible approach.").

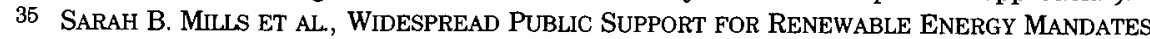
DESPITE PROPOSED ROLLBACKS 1 (2015), https://perma.cc/UP5Q-C9P7 ("A strong majority (74\%) of Americans agree that state governments should require a set portion of all electricity to come from renewable energy sources such as wind and solar power."); Monica Anderson, For Earth Day, Here's How Americans View Environmental Issues, PEw RES. CTR.: FACT TANK (Apr. 22, 2016), https://perma.cc/4PNV-KLQ4 (nearly three-quarters of U.S. adults said that "the 'country 
environmental regulations, which benefited American citizens through noticeably cleaner air and water. We have done an enormous amount to reduce many types of emissions. ${ }^{36}$ On some issues, for example lead exposure through the air, we have nearly eliminated the problem. ${ }^{37}$ In other cases, such as hazardous air pollutants from vehicles, we've made notable progress in reducing the harm. ${ }^{38}$ And even where much more remains to be done, such as reducing chemical exposures or cutting greenhouse gas emissions, the most obvious policy interventions have been adopted. As some might say, the low-hanging fruit has been harvested. ${ }^{39}$ The next increments of progress entail either higher costs or more limited public health or ecological gains, or both. ${ }^{40}$ And the scale of the funds required can be eye-popping. ${ }^{41}$ EPA estimates, for example, that its 2015 Mercury and Air Toxics Standards for power plants will cost $\$ 9.6$ billion to implement. ${ }^{42}$

should do whatever it takes to protect to the environment,"'). For an in-depth discussion of opinion polling on environmental issues, see David P. Daniels et al., Public Opinion on Environmental Policy in the United States, in THE OXFORD HANDBOOK OF U.S. ENVIRONMENTAL PoLiCY 461 (Sheldon Kamieniecki \& Michael E. Kraft eds., 2013).

36 Others have come to similar conclusions. See, e.g., Peter Lehner, The Logjam: Are Our Environmental Laws Failing US or Are We Failing Them?, 17 N.Y.U. ENVTL. L.J. 194, 196 (2008) ("[W]e've made good progress especially considering the American economy. Sulfur dioxide emissions are down; most sewage is treated; cars emit a tiny fraction of what they used to; billions of pounds of toxic water pollutants are removed from industrial wastewater; most companies since CERCLA [Comprehensive Environmental Response, Compensation, and Liability Act] was passed are very careful not to dump toxics whenever convenient; PCBs [polychlorinated biphenyls] have been banned; and lead is out of gasoline. Many wild species have not been lost and are recovering. Things are much better than they would have been without these statutes."). Furthermore, between 1970 and 2014, air pollution from carbon monoxide (CO), volatile organic (VOC), and nitrogen oxide $\left(\mathrm{NO}_{x}\right.$ ) declined by more than half, while emissions of particulate matter $\left(\mathrm{PM}_{10}\right)$ and sulfur dioxide $\left(\mathrm{SO}_{2}\right)$ fell by more than 70 percent. Air Pollutant Emissions Trends Data: Average Annual Emissions, U.S. ENVTL. PROTECTION AGENCY, https:/perma.cc/5GPP-J67T (last visited Feb. 25, 2017).

37 Lead Trends, U.S. ENVTL. PRoTECTION AGENCY, https://perma.cc/7NLQ-PLMS (last visited Feb. 25, 2017) (showing a 99\% decrease in the national average of lead concentrations in the air from $1980-2015$ ).

38 Mobile source hazardous air pollutants have declined by half since 1990. Smog, Soot, and Other Air Pollution from Transportation, U.S. ENvTL. PRoTECTION AGENCY, https://perma.cc/ 63TT-S45Z (last visited Feb. 25, 2017).

39 See, e.g., Jonathan Adler, Free and Green: A New Approach to Environmental Protection, 24 HARV. J.L. \& PUB. POL'y 653, 659 (2001); Michael P. Vandenbergh, From Smokestack to SUV: The Individual as Regulated Entity in the New Era of Environmental Law, 57 VAND. L. REV. 515, 617 (2004).

40 See A. Dan Tarlock, Environmental Law: Then and Now, 32 WASH. U. J.L. \& POL'Y 1, 9 (2010).

41 Economists Michael Greenstone, John List, and Chad Syverson, for example, estimate that EPA's national ambient air quality standards for $\mathrm{CO}$, tropospheric ozone, $\mathrm{SO}_{2}$, and $\mathrm{PM}$ cost U.S. manufacturing plants roughly $\$ 21$ billion per year. Michael Greenstone, John A. List \& Chad Syverson, The Effects of Environmental Regulation on the Competitiveness of U.S. Manufacturing 2 (Nat'l Bureau of Econ. Research, Working Paper No. 18392, 2012); see also Stephen P. Ryan, The Costs of Environmental Regulation in a Concentrated Industry, 80 ECONOMETRICA 1019, 1058 (2012) (estimating that the 1990 Amendment to the Clean Air Act cost the Portland cement industry at least $\$ 810$ million).

42 Sean Reilly \& Robin Bravender, EPA Doubles Down on Mercury Rule; More Litigation Likely, E\&E NEwS (Apr. 15, 2016), https://perma.cc/T3Q9-4PWY. 
Simply put, both the total cost of EPA rules and the question of whether the benefits of additional regulations or tighter standards exceed the costs have become big concerns. ${ }^{43}$ The reality of over-regulation (or at least inefficient regulation) in some contexts can hardly be denied. ${ }^{44}$ Indeed, outcomes where costs exceed benefits are the inevitable endpoint of a legal framework that directs regulators to ignore costs in many circumstances. ${ }^{45}$

At the same time, underregulation remains real as well. ${ }^{46}$ From the threat of climate change ${ }^{47}$ to persistent chemical exposures, ${ }^{48}$ to emerging issues, such as how to ensure the safe use of genetically-modified organisms ${ }^{49}$ or nanotechnologies, ${ }^{50}$ the work of environmental protection is not done.

43 Kenneth J. Arrow et al., Is There a Role for Benefit-Cost Analysis in Environmental, Health, and Safety Regulation, 272 SCIENCE 221, 221 (1996) ("The estimated cost per statistical life saved has varied across regulations by a factor of more than $\$ 10$ million, ranging from an estimated cost of $\$ 200,000$ per statistical life saved with the [EPA's] 1979 trihalomethane drinking water standard to more than $\$ 6.3$ trillion with EPA's 1990 hazardous waste listing for wood-preserving chemicals.").

44 T.H. Tietenberg, Economic Instruments for Environmental Regulation, 6 OXFORD REv. ECON. POL'Y 17, 24 tbl.1 (1990) (showing the costs of various command-and-control regulations exceeding least-cost options by between a factor of 1 and 22 ).

45 Michael A. Livermore \& Richard L. Revesz, Rethinking Health-Based Environmental Standards, 89 N.Y.U. L. REV. 1184, 1202 (2014) ("[O]ur case study of the lead standard shows how EPA engaged in a balancing process that cannot be done coherently without taking costs into consideration."). Jonathan S. Masur \& Eric A. Posner, Against Feasibility Analysis, 77 U. CHI. L. REV. 657, 661-62 (2010) (arguing that feasibility analysis, which does not fully take into account regulatory costs, "lacks a normative justification and should have no place in government regulation").

46 Livermore \& Revesz, supra note 45 , at 1188 (arguing that the NAAQS, in fact, are less stringent that would be required under a cost-benefit analysis); Dave Owen, Mapping, Modeling, and the Fragmentation of Environmental Law, 2013 UTAH L. REV. 219, 229 (2013) (suggesting underregulation may be the "greater problem"); Arthur Pugsley, The Myth of EPA Overregulation, 39 ECology L.Q. 475, 505 (2012) (finding that, when courts strike down EPA regulations, they are more likely to do so because the regulations are too lenient rather than too strict).

47 Richard J. Lazarus, Super Wicked Problems and Climate Change: Restraining the Present to Liberate the Future, 94 CORNELL L. REv. 1153, 1176 (2008) [hereinafter Lazarus, Super Wicked Problems] ("Just as problems that can be easily imagined may in theory prompt overregulation, problems that cannot be easily imagined-and therefore presumably implicate an 'unavailability heuristic'-may be plagued by underregulation. Climate change, of course, is just such an unimaginable problem.").

48 James T. O'Reilly, Torture by TSCA: Retrospectives of a Failed Statute, 25 NAT. RESOURCES \& ENV'T, Summer 2010, at 43, 43 ("[H]ighlight[ing] the three primary societal failings of TSCA, namely its weakness for controlling risks associated with existing chemicals, the complexity of the Significant New Use Rule (SNUR), and its rigid procedural handcuffs for ensuring transparency of safety data."); Lauren Trevisan, Comment, Human Health and the Environment Can't Wait for Reform: Current Opportunities for the Federal Government and States to Address Chemical Risks Under the Toxic Substances Control Act, 61 AM. U. L. REv. 385,387 (2011) (calling the Toxic Substances Control Act "a failure").

49 Gregory N. Mandel, Gaps, Inexperience, Inconsistencies, and Overlaps: Crisis in the Regulation of Genetically Modified Plants and Animals, 45 WM. \& MARY L. REv. 2167 (2004) (calling the regulatory system for genetically modified products "highly fractured and inefficient"); David E. Adelman \& John H. Barton, Environmental Regulation for Agriculture: Toward a Framework to Promote Sustainable Intensive Agriculture, 21 STAN. ENVTL. L.J. 3, 34- 
But today's environmental issues are different in kind from the problems of the $1970 \mathrm{~s}^{51}$ They are harder to see, more difficult to address, and often present less clear positive benefit-cost ratios, at least within the short-term time scale that drives elected representatives. Given concerns about costs and a fragile economy, policymakers must not only weigh pollution control burdens against the prospective health or ecological gains, but also balance competing goals outside the environmental arena, such as job impacts and competitiveness consequences. ${ }^{52}$

Today's environmental choices thus demand careful risk analysis and refined policy targeting. ${ }^{53}$ But in a world where good governance requires thoughtful trade-offs, ${ }^{54}$ the 20 th century model of viewing environmental harms in absolute (even moral) terms does not work well. ${ }^{55}$ Nor does the structure of law around separate environmental media, meaning that we have distinct (and sometimes conflicting) rules and requirements for air emissions, water pollution, chemical exposures, land management, and more.

35 (2002) (criticizing EPA's regulatory treatment of genetically modified plants as environmentally unsound).

50 See generally David A. Dana, The Case for an Information-Forcing Regulatory Definition of "Nanomaterials", 30 PACE ENVTL. L. REv. 441 (2013) (discussing the challenges associated with even defining what are nanomaterials); Christopher J. Preston et al., The Novelty of Nano and the Regulatory Challenge of Newness, 4 NANOETHCS 13 (2010) (discussing the unique challenges associated with regulating nanomaterials). See also Albert C. Lin, Size Matters: Regulating Nanotechnology, 31 HARv. ENVTL. L. REv. 349, 351 (2007) (arguing that existing "statutes are inadequate and that nanotechnology poses distinct and serious concerns that warrant legislation specific to the manufacture and use of nanomaterials").

51 Herman, Schoenbrod, Stewart \& Wyman, supra note 11, at 3 ("But today, almost forty years after the passage of our basic federal governing structure, we have learned more about the nature of some old environmental problems and the limits of the regulatory tools that we have used for addressing them. We are also encountering new problems. We need new tools to address many old problems more effectively and deal with the new ones.").

52 See generally Risk vs. Risk: TRADE-OFFs IN PRotecting HEALTH AND THE ENVIRONMENT (John D. Graham \& Jonathan B. Wiener eds., 1995) (discussing the importance of weighing all risks and concerns).

53 The need for new models of regulation are, of course, not unique to the environmental context. See Cary Coglianese, The Challenge of Regulatory Excellence, in ACHIEvING REGULATORY EXCELLENCE 1 (Cary Coglianese ed., 2017) (arguing that pursuit of "regulatory excellence" is more important than ever in today's increasingly complex and interconnected world).

54 Steven R. Weisman, The Values Trap: What We talk about When We talk about GLOBALIZATION 8-9 (2015) (observing that any policy choice is characterized by a number of important tradeoffs, including - among others-the tradeoff between economic efficiency and economic equality); Ted Gayer, Regulatory Equilibrium, in ACHIEVING REGULATORY EXCELLENCE, supra note 53 , at 88,88 (underscoring the need for regulators to give careful consideration to the tradeoffs and risks of regulation).

55 Richard L. Revesz, Toward a More Rational Environmental Policy, 39 HARv. ENVTL. L. REv. 93, 93-94 (2015) (noting "cost-benefit analysis provides a tractable means of weighing the tradeoffs involved in setting environmental policy between environmental goals and other social values. Improving environmental quality is not a cost-free enterprise, and decisionmakers should aim to maximize the net benefits-benefits minus costs—delivered by a policy.").

56 Herman, Schoenbrod, Stewart \& Wyman, supra note 11, at 7 ("Cross-institution and cross-media approaches are needed to address the polycentric and interconnected nature of 
Advances in ecological sciences and emerging fields like industrial ecology have demonstrated that the "silos" of our existing legal framework do not encourage consideration of the linkages across problems and the fundamental fact of ecosystem interdependence. ${ }^{57}$ And in too many cases, environmental law simply shifted problems from one form to another. ${ }^{58}$ Smokestack scrubbers, for example, cleaned the air only to produce a sludge that required careful land disposal or else unleashed a risk of contaminants leaching into nearby rivers-changing an air emissions problem into land contamination and water pollution. ${ }^{59}$ Similarly, the gasoline additive MTBE allowed car engines to burn cleaner but sometimes leaked from gas station tanks and contaminated groundwater. ${ }^{80}$

Likewise, we have come to understand that many of our residual environmental problems derive from energy policy choices. Extracting and then burning fossil fuels generates a range of pollution problems. ${ }^{61}$ In rethinking our environmental law architecture, the benefits of a more integrated or "systems" perspective have become clear. ${ }^{82}$ Specifically, we need a framework that brings related issues together and acknowledges the fact that economic constraints define the perceived policy options-often with profound consequences. If Flint, Michigan had not been in receivership

environmental problems such as climate change, the degradation of ocean environments and fishers, the loss of biodiversity, and the degradation of freshwater watersheds and rangeland."); see also Uwe M. Erling, Approaches to Integrated Pollution Control in the United States and the European Union, 15 TUL. ENVTL. L.J. 1 (2001) (discussing cross-media pollution regulation in the United States and the European Union); Robert W. Hahn \& Eric H. Malès, Can Regulatory Institutions Cope with Cross Media Pollution?, 40 J. AIR \& WASTE MGMT. ASs'N 24, 24 (1990) (observing the challenges of regulating cross media pollution in a statutory framework that addresses different media pollution independently).

67 Alan D. Hecht, Past, Present and Future Challenges to Science and Sustainability at EPA: A Review, 2 JACOBS J. ENVTL. SCI., Apr. 2016, art. 11, at 2 ("One way to break down silos is adopting an integrated and systems approach to environmental management."); Daniel J. Fiorino, Environmental Policy As Learning: A New View of an Old Landscape, 61 PUB. ADMIN. REv. 322, 326 (2001) ("Artificial distinctions among environmental media (air, water) and among policy sectors (energy, agriculture) are viewed as constraints on effective problem solving."); Carol M. Rose, Environmental Law Grows Up (More or Less), and What Science Can Do To Help, 9 LEWIS \& CLARK L. REv. 273, 287 (2005) ("Since various environmental issues and media ultimately need to be considered in conjunction, clearly a new generation of environmental law needs to pay attention to the coordination of environmental efforts.").

58 Lakshman Guruswamy, Integrated Pollution Control: The Way Forward, 7 ARIz. J. INT'L \& COMP. L. 173, 177-79 (1990); Laura Tangley, Tackling "Cross-Media" Pollution, 35 BIOSCIENCE $70,70,75$ (1985).

59 Lakshman Guruswamy, The Case for Integrated Pollution Control, LAW \& ConTEMP. ProBs., Autumn 1991, at 41, 42-45.

60 U.S. ENVTl. PROT. AgENCY, EPA REPORT 815-R-08-012, REgulatory Determinations SuPPORT DOCUMENT FOR. SELECTED CONTAMINANTS FROM THE SECOND DRINKING WateR CONTAMINANT CANDIDATE LIST 13-16 (2008).

61 The Hidden Costs of Fossil Fuels, UNION CONCERNED SCIENTISTS, https://perma.cc/6WRC85MU (last visited Feb. 25, 2017).

62 See, e.g., AMORY LOVINS \& Rocky MOUNTAIN INST., REINVENTING FIRE 24-25 (2011) (calling for an "integrative, whole-system design" to deliver more sustainable transportation); Lincoln $\mathrm{L}$. Davies, Alternative Energy and the Energy-Environment Disconnect, 46 IDAHO L. REv. 473, 475 (2010) (arguing for an overhaul of the nation's legal framework in order to better coordinate environmental and energy regulations). 
and facing deep fiscal challenges, would city officials have made the decision to shift the source of drinking water for the city from a wellestablished public water system to the highly contaminated Flint River for a savings of five million dollars over two years? ${ }^{63}$

As attractive as simple solutions might be, very few of the problems we now face are amenable to black-and-white thinking. The next increments of progress require decision frameworks that provide a way to balance competing virtues-costs and benefits-within a gray zone of uncertainty ${ }^{64}$ Thus, the policy approach that got us where we are today is not going to get us to where we need to go tomorrow. The issues we face now come in the form of questions like: Should the permitted standard for ground-level ozone (the main precursor of smog and the source of known respiratory harms) be lowered from $70 \mathrm{ppm}$ to $60 \mathrm{ppm}$ ? We know that some number of people would benefit from reduced ozone exposure. ${ }^{65}$ But what would this reduction cost? How many people would breathe easier with the lower standard? And how much is that respiratory gain worth? Our emerging environmental policy questions require careful data and analysis-and a much finer calibration of the marginal costs and benefits of further pollution control efforts. ${ }^{66}$

Simply put, the 20th century command-and-control model not only struggles with the optimization of costs and benefits within the framework of the regulatory choices to be made, but also fails to provide a systematic way to balance potential environmental gains against other important interests outside of the environmental arena, including economic vitality and job security. ${ }^{67}$ More fundamentally, the commitment to regulationgovernment-defined standard setting and behavioral mandates-as the central strategy of environmental protection arose in an era of limited information. ${ }^{68}$ In those circumstances, it made sense to have a government

63 Peter Muennig, Letter, The Social Costs of Lead Poisonings, 35 HEaLth AFF. 1545 (2016).

64 See generally RICHARD L. REVESZ \& MICHAEL A. LIVERMORE, RETAKING RATIONALTTY: HOW

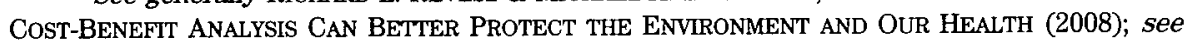
also Daniel A. Farber, Coping with Uncertainty: Cost-Benefit Analysis, The Precautionary Principle, and Climate Change, 90 WASH. L. REv. 1659 (2015) (discussing cost-benefit analyses in the context of climate change uncertainty); Cass R. Sunstein, Financial Regulation and CostBenefit Analysis, 124 YALE L.J.F. 263, 263 (2015) (noting that cost-benefit analyses can be modified when agencies face "serious gaps in knowledge").

65 National Ambient Air Quality Standards for Ozone, 80 Fed. Reg. 65,292, 65,294 (Oct. 26, 2015) (codified at 40 C.F.R. pts. 50-53 \& 58).

66 For a comprehensive discussion of calculating environmental regulatory costs, see William A. Pizer \& Raymond Kopp, Calculating the Costs of Environmental Regulation, in HANDBOOK OF ENVIRONMENTAL ECONOMICS: ECONOMYWIDÉ AND INTERNATIONAL ENVIRONMENTAL Issues 1308 (Karl-Göran Mäler \& Jeffrey R. Vincent eds., 2005).

67 Richard B. Stewart, United States Environmental Regulation: A Failing Paradigm, 15 J.L. \& Сом. 585, 587-90 (1996).

68 Daniel H. Cole \& Peter Z. Grossman, Toward a Total-Cost Approach to Environmental Instrument Choice, in AN INTRODUCTION TO THE LAW AND ECONOMICS OF ENVIRONMENTAL POLICY: Issues IN INSTTTUTIONAL DESIGN 223, 234 (Timothy Swanson ed., 2002) ("When the U.S. Clean Air Act was first enacted in 1970, for example, Congress could not have relied on effluent taxes, tradeable permits, or any other regime that depended on low-cost, precise, and continuous emissions monitoring because the necessary technology did not then exist."). 
entity-EPA—spot pollution problems, assess the harms and risk, and set uniform national standards that polluters had to obey. ${ }^{69}$ We had no other reliable mechanism for pollution monitoring and control. ${ }^{70}$ Living today in the Digital Age, we have many other tools and policy options, as Parts IV and $\mathrm{V}$ below spell out in detail.

\section{Operational Shortcomings}

The third obstacle to progress arises from our past preoccupation with establishing rules and too little focus on results. The 20th century approach to environmental protection made what I like to call the lawyer's mistake: we passed laws, wrote regulations, and signed treaties-and thought the job was done. ${ }^{71}$ Too much time and energy went into defining the legal framework and establishing targets and timetables-and too little attention was paid to program implementation and the incentives required to change behavior and deliver better results. ${ }^{72}$ Too often the answer to missed targets was simply to readjust the compliance timetable (and sometimes even to set more demanding targets at the same time) with no focus on the inadequacy of the incentives for investment in technological gains or other pathways to progress. $^{73}$

69 Sidney A. Shapiro \& Thomas O. McGarity, Not So Paradoxical: The Rationale for Technology-Based Regulation, 1991 DUKE L.J. 729, 746 (1991) (noting that Congress amended the Clean Air Act and Clean Water Act to allow EPA to implement technology-based standards when Congress "recognized that the overwhelming uncertainties and analytical quagmires concerning risk assessment were bogging down the [earlier] toxic substance programs").

70 Thomas O. McGarity, Media-Quality, Technology, and Cost-Benefit Balancing Strategies for Health and Environmental Regulation, LAw \& CONTEMP. ProBS., Summer 1983, at 159, 210 ("Enforcement costs for a technology-based approach can run considerably less than mediaquality monitoring costs. While technology-based standards normally specify numerical limitations for individual facilities, the limitations are based upon the pollution removal capacity of a particular technology or its equivalent. The enforcement officer can normally infer that the numerical limitations are being met from the fact that the technological components are running properly, without monitoring actual discharges. This greatly simplifies the enforcement process because the enforcement officer need only check to see if the pollution control equipment is being properly used and maintained and observe recorded evidence that the equipment was in fact turned on during the relevant enforcement period.").

71 This phenomenon is not unique to environmental regulations or the United States. Governments from around the globe have paid "remarkably little attention to analyzing regulations after adoption or to evaluating the impacts of the procedures and practices that govern the regulatory process itself, so-called regulatory policy." CARY COGLIANESE, ORG. FOR ECon. Co-operation \& Dev., Measuring Regulatory Performance: Evaluating the Impact of REgUlation AND REgUlatory POLICY 7 (2012).

72 Robert W. Hahn, Regulatory Reform: Assessing the Government's Numbers 14 (Am. Enter. Inst.-Brookings Joint Ctr. for Regulatory Studies, Working Paper No. 99-6, July 1999), https://perma.cc/3X8Y-N3PU (estimating that, while final regulations promulgated from 1981 to 1996 generated $\$ 1.6$ trillion in benefits, less than half passed cost-benefit tests); Daniel A. Farber, Taking Slippage Seriously: Noncompliance and Creative Compliance in Environmental Law, 23 HARV. ENVTL. L. REv. 297, 304 (1999) (stressing that "translating legal mandates into actual compliance is far from automatic $c^{n}$.

73 Ian Ayres \& Amy Kapczynski, Innovation Sticks: The Limited Case for Penalizing Failures to Innovate, 82 U. CHI. L. REv. 1781 app. at 204 (2015) (describing how California had to 
The mistake here is a common one: focusing on inputs rather than outcomes as a gauge of success. ${ }^{74}$ To be clear, laws matter. We need statutes and rules to guide behavior. But passing an environmental law is not the same thing as solving an environmental problem. ${ }^{75}$ Success cannot be declared based on growth in agency budgets, staffing levels, or the number of enforcement actions brought. ${ }^{76}$ Progress needs to be measured in terms of breathable air, drinkable water, and uncontaminated land.

Ironically, no one in the corporate world would have made this mistake. Business people would have understood that getting a law passed was the equivalent of developing a business plan, or maybe simply issuing a mission statement. The real job depends on execution. Success cannot be declared until the business plan delivers measurable results, which often entails trial and error, refined thinking, and strategy adjustments. ${ }^{77}$ This commitment to continuous improvement and systematic reform has been absent from our environmental policy efforts for more than two decades. ${ }^{78}$

postpone and weaken its zero-emission vehicle mandate in the face of industry opposition); Farber, supra note 64, at 304 (noting that EPA has repeatedly missed Clean Air Act deadlines); Richard B. Stewart, Regulation, Innovation, and Administrative Law: A Conceptual Framework, 69 CALIF. L. REV. 1256, 1303 (1981) [hereinafter Stewart, Regulation, Innovation and Administrative Law] (describing how EPA repeatedly delayed pollution standards for new automobiles throughout the $1970 \mathrm{~s}$ in response to anticipated compliance failure, rather than innovate incentives for progress); Richard B. Stewart, A New Generation of Environmental Regulation?, 29 CAP. U. L. REV. 21, 56 (2001) [hereinafter Stewart, New Generation] ("EPA encountered long delays in issuing uniform federal technology-based effluent limitation regulations for point sources, exceeding statutory deadlines in some cases by ten or more years.").

74 Claudio Radaeldu \& Oliver Fritsch, Org. For Econ. Co-operation \& Dev., Measuring Regulatory Performance: Evaluating Regulatory Management ToOls and Programmes 7 (2012) (finding that, among OECD countries, "governments have been less active in adopting output and intermediary outcome indicators" for assessing regulatory quality); John D. Graham, Legislative Approaches to Achieving More Protection against Risk at Less Cost, 1997 U. CHI. LEGAL F. 13, 28-29 (1997) (arguing that "a reallocation of resources from cost-ineffective to cost-effective programs" could save thousands of lives and billions of dollars annually in the United States).

75 See generally Jan G. Laitos \& Laruen Joseph Wolongevicz, Why Environmental Laws Fail, 39 WM. \& MARY ENVTL. L. \& POL'Y REV. 1, 3-4 (2014) (documenting the variety of environmental laws that are on the books, as well as the continued decline in environmental quality along a number of environmental indicators, and asking: "Why have all these laws been unable to do the job?").

76 Joel A. Mintz, Measuring Environmental Enforcement Success: The Elusive Search for Objectivity, 44 Envtl. L. Rep. (Envtl. L. Inst.) 10,751, 10,753 (Sept. 2014) (outlining the various shortcomings of input metrics).

77 See, e.g., Christopher D. Ittner \& David F. Larcker, Coming Up Short on Nonfinancial Performance Measurement, HARv. BuS. REv., 2003, at 88, 88 (noting that companies are increasingly relying on nonfinancial performance measures, such as metrics for customer loyalty and employee satisfaction); Robert S. Kaplan \& David P. Norton, The Balanced Scorecard-Measures that Drive Performance, HARv, BUS. REv., Jan.-Feb. 1992, at 172, 172 ("Senior executives understand that their organization's measurement system strongly affects the behavior of managers and employees.").

78 Freeman \& Spence, supra note 6 , at 80 (observing that the updating of environmental statutes is all but impossible in today's era of unprecedented political polarization). 
There are now many visible shortcomings of the 20th century legal framework. One of the most serious failures was the limited attention paid to where the money would come from for the environmental investments that were being called for. The Safe Drinking Water Act $^{79}$ set up a state revolving loan fund to help finance infrastructure investments in public water systems, ${ }^{80}$ and a fund was established to cover the cost of cleaning up toxic waste dumps where no private party could be sent the bill. ${ }^{81}$ With these limited exceptions-both of which have been curtailed in recent decades ${ }^{82}$ our existing environmental laws largely assumed that private parties would come forward with the money required to install pollution controls and build out environmental infrastructure. ${ }^{83}$ In practice, our biggest factoriessometimes called the "big dirties"-have been pressed to install pollution control equipment, and the billions of dollars that have been invested have produced substantial environmental gains. ${ }^{84}$

But in many other circumstances, the money needed has not been forthcoming. In too many cases across the nation, communities that cannot afford upgrades now rely on decaying drinking water pipes and purification systems, aging and insufficient sewage treatment plants, and crumbling transportation infrastructure. ${ }^{85}$ Likewise, the limited capacity of small businesses to make required environmental investments has often been overlooked. Simply put, too many pollution control programs have focused on enforcement, rather than being designed to facilitate compliance and ensure improved performance. ${ }^{86}$

Indeed, many of the core performance metrics of EPA and of state-level departments of environmental protection have centered on Notices of Violation issued, enforcement actions brought, and fines paid-not on actual environmental progress. ${ }^{87}$ While corporate misbehavior must be disciplined,

7942 U.S.C. $\$ \S 300$ to $300 \mathrm{j}-25$ (2012).

$80 I d . \S 300 \mathrm{j}-12$, amended by Water Infrastructure Improvements for the Nation Act, Pub. L. No. 114-322, § 2103, 130 Stat. 1628, 1718 (2016).

81 Superfund: CERCLA Overview, U.S. ENVTL. PROTECTION AGENCY, https://perma.cc/9UVF9YC6 (last visited Feb. 25, 2017).

82 Charles Duhigg, That Tap Water Is Legal but May Be Unhealthy, N.Y. TIMEs, Dec. 17, 2009, at A1; John M. Broder, Without Superfund Tax, Stimulus Aids Cleanups, N.Y. TIMES, Apr. 26,2009 , at A16.

83 See Pizer \& Kopp, supra note 66, at 1313 tbl.1 (reviewing the estimated costs of environmental regulations on taxpayers and industry).

84 See, e.g., National Enforcement Initiative: Reducing Air Pollution from the Largest Sources, U.S. ENVTL. PROTECTION AGENCY, https://perma.cc/3W3S-UTQE (last visited Feb. 25, 2017).

85 See generally AM. SOC'Y OF CIVL ENG'RS, 2017 INFRASTRUCTURE REPORT CARD: A COMPREHENSIVE ASSESSMENT OF AMERICA'S INFRASTRUCTURE (2017), https://perma.cc/V3PL-GU52.

86 Lloyd Dixon et al., The Impact of Regulation and Litigation on Small businesses and Entrepreneurship: An Overview, in IN THE NAME OF ENTREPRENEURSHIP? THE LOGIC AND EFFECTS of SPEcial Regulatory TrEatment For SMall Businesses 17, 37-38 (Susan M. Gates \& Kristin J. Leuschner eds., 2006) ("Environmental regulations may more heavily impact small firms because of compliance asymmetries, statutory asymmetries, and enforcement asymmetries.").

87 Robert EsWorthy, CONG. RESEARCH SERV., RL34384, FEDERAL POlLUTION CONTROL LaWS: HOW ARE THEY ENFORCED? 42 (2014) ("Critics contend, and EPA has long recognized, that while somewhat indicative of the failure to comply with environmental requirements, counting 
the 21 st century focus should be on compliance not on penalties. ${ }^{88}$ While willful misconduct might have been prevalent in the 1970s, it is much rarer today. ${ }^{89}$ There will be occasional instances of egregious misbehavior, such as Volkswagen's evasion of tailpipe emissions controls, ${ }^{90}$ and this sort of cheating should be severely punished. ${ }^{91}$ In many circumstances, including much of the performance shortcomings of small businesses, the failure is much more likely to derive from lack of understanding or limited capacity than from intentional violations of law. ${ }^{92}$

Another implementation problem relates to the fact that several laws (most notably the Clean Air Act) "grandfathered" highly polluting existing facilities while setting more stringent standards for new equipment. ${ }^{93}$ This two-tiered set of requirements created a powerful incentive to keep old, heavily-polluting, power plants and factories in operation rather than build new facilities that would need to meet more demanding and costly standards. ${ }^{94}$ Indeed, as Richard Revesz and Jack Lienke have documented,

enforcement actions alone ('bean counting') does not provide a complete measure of the effectiveness of the national environmental enforcement/compliance program."); NAT'L ACAD. of Pub. Admin., Evaluating Environmental Progress: How EPA and the States Can Improve THE QUALTTY OF ENFORCEMENT AND COMPLIANCE INFORMATION 10-11 (2001) ("Traditionally, EPA and the state environmental agencies have measured the performance of enforcement and compliance assistance programs by counting the number of inspections conducted, enforcement actions pursued, and penalties collected ....”).

88 As Cynthia Giles, Assistant Administrator for EPA's Office of Enforcement and Compliance Assurance, notes: "While enforcement is an essential part of EPA's compliance program, it is not realistic to think that enforcement alone will get us to the levels of compliance envisioned by our rules. We can get a bigger bang for the buck by working hard to make sure we design rules that will work in the real world-rules with compliance built in." Cynthia Giles, Next Generation Compliance, ENvTL. F., Sept.-Oct. 2013, at 22, 23.

'89 For example, criminal enforcement actions, which are only pursued against knowing violators of federal pollution control laws, make up a small share of EPA enforcement actions. EsWORTHY, supra note 87 , at 45,48 tbl.B-2.

90 Sonari Glinton, Volkswagen Agrees to $\$ 14.7$ Billion Settlement in Emissions Cheating Scandal, NAT'L PUB. RADIO (Oct. 25, 2016), https://perma.cc/466Z-MCUU.

91 Too many of today's enforcement cases relate to paperwork errors rather than serious environmental risks. Jaṃes Alm \& Jay Shimshack, Environmental Enforcement and Compliance: Lessons from Pollution, Safety, and Tax Settings, 10 Found. \& TRENDS iN MiCROECONOMICS 209, 222-27 (2014) (pointing to empirical evidence that polluters, on average, report emissions data accurately); Wayne B. Gray \& Jay P. Shimshack, The Effectiveness of Environmental Monitoring and Enforcement: A Review of the Empirical Evidence, 5 REV. ENVTL. ECON. \& POL'Y 3, 19 (2011) (underscoring the efficiency gains from targeting enforcement on the worst-performing facilities and noting that environmental enforcement is not always well tailored to pollution violators).

92 Dixon et al., supra note 86 , at 18 (observing that there may be economies of scale to complying with environmental regulations, meaning that smaller firms may find compliance harder to achieve than larger firms).

93 RICHARD REvesZ \& JACK LIENKE, STRUgGLING FOR AIR: POWER PLANTS AND THE “WAR ON COAL" 30-31 (2016).

94 Id. at 30-32; see also Robert N. Stavins, Vintage-Differentiated Environmental Regulation, 25 STAN. ENVTL. L.J. 29, 31 (2006) (noting that a number of environmental statutes contain this two-tiered feature, including the Clean Water Act, the Safe Drinking Water Act, and laws regulating hazardous waste). 
the expected lifespan of coal plants built in the 1970 s was thirty years. ${ }^{95}$ But today, more than $75 \%$ of U.S. coal-fired generation has been online for more than three decades, nearly $40 \%$ has been running for more than four decades, and roughly $20 \%$ have passed the half-century mark. ${ }^{96}$ Not surprisingly, prolonging the life of these older, dirtier power plants has detrimentally impacted air quality in the United States. ${ }^{97}$ In fact, if all existing plants simply met the emission standards for new plants, sulfur dioxide $\left(\mathrm{SO}_{2}\right)$, nitrogen oxides $\left(\mathrm{NO}_{\mathrm{x}}\right)$, and mercury emissions would fall dramatically. ${ }^{98}$

In addition, in crafting our laws and regulations without sufficient focus on implementation, too little attention has been given to how legal requirements might translate into incentives to change behavior and what the actual impact on the environment might be. Even less focus was given to second-order effects. Thus, for example, our statutory framework to address abandoned toxic waste sites-the Comprehensive Environmental Response, Compensation, and Liability Act $^{99}$ (CERCLA or Superfund)-set out standards of strict and unlimited as well as joint and several liability for those who might be responsible. ${ }^{100}$ On one hand, these tough standards have succeeded to the extent that they encouraged focused hazardous waste managers to focus on the need for much greater care in how they dispose of potentially dangerous chemicals. ${ }^{101}$

But on the other hand, these same liability rules have meant that many contaminated properties became "brownfields" that no developer dares to buy and refurbish because the clean-up risks and potential costs are too great. $^{102}$ While some effort has been made to refine the law and protect

95 REVESZ \& LIENKE, supra note 93 , at 33.

96 Id.

97 Stavins, supra note 94 , at 55 .

98 Frank Ackerman et al., Grandfathering and Coal Plant Emissions: The Cost of Cleaning Up the Clean Air Act, 27 ENERGY POL'Y 929, 935 (1999) (estimating that elimination of the Clean Air Act's "grandfather rules" would reduce $\mathrm{SO}_{2}$ and $\mathrm{NO}_{x}$ emissions by $40 \%$ and $15 \%$, respectively).

99 Comprehensive Environmental Response, Compensation, and Liability Act of 1980, 42 U.S.C. $\$ \S 9601-9675$ (2012).

100 Id. \$9607; see also Owen T. Smith, The Expansive Scope of Liable Parties under CERCLA, 63 ST. JOHN'S L. REv. 821, 822-24 (1989) (discussing the broad liability standard under CERCLA).

101 Michael Faure, Effectiveness of Environmental Law: What Does the Evidence Tell Us?, 36 WM. \& MARY ENVTL. L. \& POL'Y REV. 293, 301-02 (concluding, based on a review of the literature, that environmental liability under CERCLA incentivizes care in hazardous waste management) (2012); Edmund B. Frost, Strict Liability as an Incentive for Cleanup of Contaminated Property, 25 Hous. L. REv. 951, 952 (1988) (arguing that the strict liability standard under CERCLA functions as "a strong deterrent against future contamination"); Michael B. Gerrard, A Proposal to Use Transactions to Leverage Environmental Disclosure and Compliance, in MOVIng TO MARKETS IN ENVIRONMENTAL REgulation: LeSSONS FROM TWENTY YEARS OF EXPERIENCE 420, 421-22 (Jody Freeman \& Charles D. Kolstad eds., 2007) ("[CERCLA made] companies wary of generating, treating, storing, or disposing of hazardous wastes if they could avoid it, because a history of such activities could impede their ability to attract buyers or financing.").

102 Robert H. Abrams, Superfind and the Evolution of Brownfields, 21 WM. \& MARY ENVTL. L. \& POL'Y REV. 265, 273 (1997) ("The creation of a class of pariah parcels at which lenders and developers are deterred from investing, raises a national concern that Superfund, despite 
"innocent purchasers," ${ }^{103}$ the onerous liability rules and resulting risks continue to exert a chill on redevelopment of old industrial sites in many parts of the country. ${ }^{104}$ As with our other basic statutes, a systematic review and refinement of CERCLA's legal framework and liability rules has not been undertaken. ${ }^{105}$

Another shortcoming with the existing legal framework is the time and expense that regulated facilities are required to devote to getting the "permits" they need for their water and air emissions. ${ }^{106}$ Four decades into the implementation of the Clean Air Act and the Clean Water Act, ${ }^{107}$ and after years of public administration "Reinventing Government" initiatives that emphasized efficient and effective regulatory practices, ${ }^{108}$ you might expect that permitting programs would be highly refined and designed for ease of access. However, this sort of optimization has largely not been undertaken. ${ }^{109}$ Speed has only recently been recognized as a regulatory virtue. ${ }^{110}$ A number of states have come to understand the need for more customer facing permitting systems. Connecticut, for example, recently reconfigured its twenty-six different permitting programs to reduce paperwork, cut waiting times, eliminate the backlog of pending permit applications, and lower compliance costs. ${ }^{111}$ And EPA has launched an e-government initiative in

whatever good it may do at major sites of contamination, places a host of less contaninated sites in jeopardy of remaining either unused or underused, and in continuing need of remediation."); see also David Slutzky \& A.J. Frey, Brownfields Uncertainty: A Proposal to Reform Superfund, 12 CITYSCAPE, no. 3,2010, at 85, 87 ("In fact, many would argue that the threat of Superfund liability is the single greatest impediment to the redevelopment of brownfield sites.").

103 Small Business Liability Relief and Brownfields Revitalization Act, Pub. L. No. 107-118, 115 Stat. 2356 (2002) (codified at 42 U.S.C. $\$ \$ 9601,9604,9605,9607,9622,9628$ (2012)) (bolstering the innocent landowner defense).

104 Estimates of the number of brownfield sites currently in existence in the United States range from nearly 500,000 to more than 1 million. Slutzky \& Frey, supra note 102 , at 86 .

105 See, e.g., Jonathan H. Adler, Reforming Our Wasteful Hazardous Waste Policy, 17 N.Y.U. ENVTL. L.J. 724, 756 (2008) (calling for fundamental reforms of CERCLA that would shift more responsibility to state governments).

106 Terry Davies et al., Res. FOR the Future, Reforming PERmitTing (2001) (describing extensive inefficiencies in water and air pollution permitting programs).

107 Federal Water Pollution Control Act, 33 U.S.C. $\$ \S 1251-1387$ (2012).

108 See generally DAVID OSBORne \& TED GaEBleR, REINVENTING Government: How the ENTREPRENEURIAL SPIRIT IS TRANSFORMING THE PUBLIC SECTOR (1993).

109 Claudia Copeland, Cong. Research Serv., Rl33632, Clean AIR Permitting: IMPLEMENTATION AND ISSUES 7 (2016) ("[T]here also has been widespread dissatisfaction with the [Title V] program as it exists, due to program complexity; confusion and uncertainty about some of its requirements; and criticism of costs to regulated entities, permit agencies, and even the general public."); DAVIES ET AL., supra note 106, at 9 ("Both the states and EPA regions have a large backlog of expired NPDES water permits, and a similar problem is likely to occur with Title $\mathrm{V}$ air permits.... The [permitting] system is also opaque, fragmented, and inefficient....").

110 See, e.g., Daniel Esty, Regulatory Transformation: Lessons from Connecticut's Department of Energy and Environmental Protection, 76 PUB. ADMIN. REv. 403, 404 (2016) [hereinafter Esty, Regulatory Transformation].

11i Id. at 407. Connecticut used the "lean" tool developed in industry to re-engineer complex systems. For more information about lean, see generally PASCAL DENNIS, THE REMEDY: BRINGING LEAN THINKING OUT OF THE FACTORY TO TRANSFORM THE ENTIRE ORGANIZATION (2010). 
conjunction with the Environmental Council of the States designed to streamline regulatory processes. ${ }^{112}$ However, the potential for "smart regulation" has only just begun to be tapped. ${ }^{11}$

Today's environmental laws also fall short in terms of perceived fairness. ${ }^{114}$ The fact that significant harms remain unabated and certain segments of the population face disproportionate pollution impacts raises significant environmental justice concerns. ${ }^{1.5}$ We often fail to ask: Who bears the cost of inaction with regard to pollution harms? Should those suffering from these harms be compensated? Is access to natural resources fairly distributed?

At the same time, we should ask whether pollution control or habitat protection costs are being allocated in ways that make sense and meet basic standards of fairness. ${ }^{116}$ The many controversies over regulatory takings show how contentious these questions can be ${ }^{177}$ In this regard, shouldn't society compensate those providing ecosystem services, such as habitat for endangered species? ${ }^{118}$ Absent such payments for positive externalities, ${ }^{119}$ we

112 Thomas S. Burack \& A. Stanley Meiburg, Collaborative Federalism, ENvTL. F., May-June 2016, at 23, 24-26 (describing the history and function of the E-Enterprise initiative).

113 Beth Simone Noveck, Smart Citizens, Smarter State: The Techinologies of Expertise AND THE FUTURE OF GOVERNING 1-2 (2015) (outlining how open government initiatives can make governance more effective by helping government institutions better connect with-and tap into the expertise and capacity of-people and businesses); CASS R. SUNSTEIN, SIMPLER: THE FUTURE OF GOVERNMENT 1 (2014) (making the case that government can produce better results by simplifying unnecessarily complex regulations and making them more user friendly).

114 Sheldon Gen et al., Perceptions of Environmental Justice: The Case of a U.S. Urban Wastewater System, 20 SUSTAINABLE DEV. 239, 241 (2010) (reviewing numerous empirical studies documenting environmental inequities); Alice Kaswan, Environmental Justice: Bridging the Gap Between Environmental Laws and "Justice", 47 AM. U. L. REv. 221, 256-68 (1997) (discussing how perceptions of the unequal distribution of environmental benefits and burdens sparked the emergence of the environmental justice movement). See generally Paul Mohai et al., Racial and Socioeconomic Disparities in Residential Proximity to Polluting Industrial Facilities: Evidence from the Americans' Changing Lives Study, 99 AM. J. PUB. HEALTH S649 (2009) (reviewing research on racial and socioeconomic disparities in the distribution of environmental harms).

115 Charles Lord \& Keaton Norquist, Cities as Emergent Systems: Race as a Rule in Organized Complexity, 40 ENVTL. L. 551, 557-58 (2010). For a review of environmental justice concerns raised by climate change and global warming mitigation policies, see Michael $\mathbf{B}$. Gerrard, What Does Environmental Justice Mean in an Era of Global Climate Change?, 19 J. ENVTL. \& SustaINABILTY L. 278 (2013).

116 See generally Richard J. Lazarus, Fairness in Environmental Law, 27 ENVTL. L. 705 (1997) (arguing that environmental law should be reformed to better address concerns about fairness). But see Shi-Ling Hsu, Fairness Versus Efficiency in Environmental Law, 31 EcologY L.Q. 303 (2004) (arguing that the focus of environmental statutes on fairness has led to perverse consequences and that environmental law would improve by focusing more on efficiency).

117 Richard J. Lazarus, Environmental Law and the Supreme Court: Three Years Later, 19 PACE ENVTL. L. REV. 653, 655 (2002) (noting "a seemingly never-ending series of regulatory takings challenges to environmental land use restrictions").

118 Of course, landowners can receive tax breaks in some contexts, for example, by placing a conservation easement on their property. See Bradford Updike \& Bryan Mick, Conservation Easements: The Federal Tax Rules and Special Considerations Applicable to Syndicated Transactions, 49 CREIGHTON L. REv. 293, 295-96 (2016). However, more and better tailored policies are needed to compensate for ecosystem services provided by private property owners. 
risk ongoing battles over land use in contexts such as Endangered Species Act ${ }^{120}$ implementation, not to mention under-investment in critical aspects of environmental protection that occur on private land, including wetlands protection, conservation of biodiversity, and open space preservation. ${ }^{121}$

The inattention to implementation and incentives for changed behavior has been compounded by a lack of systematic review and reconsideration of our environmental programs, policies, and potential best practices. ${ }^{122} \mathrm{~A}$ command-and-control regulatory structure with its emphasis on best available technology mandates tends to chill innovation and lock in existing technologies. ${ }^{123}$ Add to this bias toward the status quo the difficulty of undertaking policy reform in the context of deep political divisions, and it is no wonder that we have not seen much in the way of policy retooling. ${ }^{124}$ Progress toward a sustainable future thus requires not only reframed politics and policy structures but also fundamental operational adjustments in the practice of environmental protection to integrate the learning of the past fifty years from both public administration and other realms, such as corporate management, behavioral economics, and social justice.

In sum, while our air and water are much cleaner today than they were half a century ago, the pace of environmental progress has now slowed, the pushback on regulatory burden has intensified, and many efforts to take up new issues or strengthen programs have been rebuffed. Simply put, America's environmental regime is now well past its "start-up" phase and long overdue for re-evaluation and updating.

119 In addition, many existing systems of compensation for environmental benefits may need to be retooled in light of climate change considerations. For example, some scholars have argued that global warming threatens the effectiveness of conservation easements, many of which lack the legal flexibility necessary to adapt to climate-driven changes. See, e.g., Adena $R$. Rissman et al., Adapting Conservation Easements to Climate Change, 8 ConSERvaTion LeTTERs 68,74 (2015).

120 Endangered Species Act of 1973, 16 U.S.C. $\$ \$ 1531-1544$ (2012).

121 Margaret Walls \& Anne Riddle, Biodiversity, Ecosystem Services, and Land Use: Comparing Three Federal Policies 12 (Res. for the Future Discussion Paper No. 12-08, 2012) (noting that private landowners tend to undersupply unpriced ecosystem and biodiversity services, and arguing that the Conservation Reserve Program, which pays farmers to conserve land, has been highly successful, while the Endangered Species Act creates a number of perverse incentives).

122 To be sure, EPA has embarked on a number of systematic policy reviews, such as the agency's 2010 Path Forward project. Paul T. Anastas, Fundamental Changes to EPA's Research Enterprise: The Path Forward, 46 ENVTL. SCI. \& TECH. 580, 580 (2012) (noting that "EPA's Path Forward has begun to address this need for systematic incorporation by realigning EPA's entire research enterprise around the concept of sustainability"). More, however, is needed.

123 Cass R. Sunstein, Paradoxes of the Regulatory State, 57 U. CHI. L. REV. 407, 420 (1990) (arguing that best available technology standards have perverse consequences because they eliminate the incentive to innovate beyond the mandated pollution level).

124 Barbara Sinclair, Is Congress Now the Broken Branch?, 2014 UTAH L. REv. 703, 713-19 (2014) (discussing the challenges of making law during periods of extreme political polarization). 


\section{CORE PRINCIPLES FOR 21ST CENTURY SUSTAINABILITY}

In this Part, I identify four pillars on which a reformed sustainability strategy should be built-responding to the political, structural, and operational deficiencies spelled out in Part II.

\section{A. The End of Externalities}

The most important step toward resolution of the shortcomings of the 20th century environmental approach would be adoption of the Polluter Pays Principle and a commitment to the end of externalities-pollution spillovers that are "permitted" rather than paid for. By moving away from the existing command-and-control framework, with its government-determined pollution control requirements, toward a legal structure that requires polluters to pay for the harms they cause (and insists that those who use shared natural resources pay for this consumption) but gives them flexibility in whether and how to adjust their behavior, we could achieve the twin goals of a more efficient and effective environmental regime.

A carefully structured system of harm charges could meet simultaneously the demands for lower costs and better results. ${ }^{125}$ It could be used to tighten standards where environmental problems persist and, at the same time, reduce burdens and provide expanded choices in terms of compliance strategies. ${ }^{126}$ A system of price signals offers the promise of lower regulatory agency administrative expenses (that taxpayers must bear) as well as reduced compliance costs (that the regulated community must absorb) ${ }^{127}$ In potentially providing greater benefits at lower costs, it could address many of the political, structural, and operational shortcomings that weigh down the existing framework of environmental law.

While path dependency and the power of inertia must be overcome, ${ }^{128}$ such a regime would have many virtues and could provide the common

125 Bruce A. Ackerman \& Richard B. Stewart, Reforming Environmental Law, 37 STAN. L. REv. 1333, 1341-47 (1985) (discussing a system of marketable permits to reform and improve the best available technology system and also offer administrative advantages); Stewart, Regulation, Innovation and Administrative Law, supra note 73, at 1327-28 (discussing how a fee system can provide substantial advantages for encouraging market and social innovation while improving social performance).

126 Robert N. Stavins, Experience with Market-Based Environmental Policy Instruments 2 (Res. for the Future Discussion Paper No. 01-58, 2001) ("Holding all firms to the same target can be expensive and, in some circumstances, counterproductive. While standards may effectively limit emissions of pollutants, they typically exact relatively high costs in the process, by forcing some firms to resort to unduly expensive means of controlling pollution. Because the costs of controlling emissions may vary greatly among firms, and even among sources within the same firm, the appropriate technology in one situation may not be appropriate (costeffective) in another. Thus, control costs can vary enormously due to a firm's production design, physical configuration, age of its assets, or other factors.").

127 Daniel C. Esty, Environmental Protection in the Information Age, 79 N.Y.U. L. REv. 115, 125 (2004) [hereinafter Esty, Information Age] (observing that market-based regulations tend to have lower administrative costs than command-and-control regulations).

128 Gregory C. Unruh, Escaping Carbon Lock-In, 30 ENERGY POL'Y 317, 317 (2002) (arguing that "industrial countries have become locked-into fossil fuel-based energy systems through 
ground needed to bring Republicans and Democrats together in support of a sweeping environmental reform agenda. Republicans would get an approach to environmental protection grounded in property rights and market-based regulatory mechanisms that promise greater efficiency, lower costs, and more flexibility than today's command-and-control structure. ${ }^{129}$ The shift away from government-defined obligations would create much greater scope for business and individual choice-consistent with the Republican core principles of liberty and a more limited sphere of government. ${ }^{130}$ And more carefully calibrated environmental policies and the elimination of requirements which entail costs that exceed benefits would reduce the regulatory burden on business. A lighter regulatory framework would improve the competitiveness of American companies in global markets and enhance prospects for economic growth and new jobs ${ }^{131}$-fulfilling several Republican goals for environmental regulatory reform.

Democrats would also win. With a regime of harm charges in place, persistent environmental problems on which there has been no progress for decades would get renewed focus. From residual air pollution that has been traced to rising asthma rates ${ }^{132}$ to climate change, pricing emissions would create powerful incentives for environmental care-and spur innovation in support of new technologies and other strategies to reduce ongoing harms at lower costs. ${ }^{133}$ A lighter environmental protection regime would also reduce

path dependent processes" and that escaping carbon lock-in will require dismantling the technological, organizational, social and institutional advantages that fossil fuels have accrued over the decades).

129 Lawrence H. Goulder \& Ian W.H. Parry, Instrument Choice in Environmental Policy, 2 REV. ENVTL. ECON. \& POL'Y 152, 155-59 (2008) (comparing direct regulatory policies (commandand-control instruments), which are generally less cost-effective, with incentive-based policies which are the most cost-effective). See generally Robert W. Hahn \& Robert N. Stavins, Incentive-Based Environmental Regulation: $A$ New Era from an Old Idea?, 18 Ecology L.Q. 1 (1991) (examining the emergence of market-based environmental protection ideas to combat pollution and global climate change); Stewart, Regulation, Innovation and Administrative Law, supra note 73 , at 1327-29 (discussing how a fee system can spur on social innovation at less cost than a regulatory agency); Robert N. Stavins \& Bradley W. Whitehead, The Next Generation of Market-Based Environmental Policies (Res. for the Future Discussion Paper No. 97-10, 1996) (discussing the potential cost-savings and positive societal impact of market-based instruments and proposing a roadmap for improving this tool to tackle environmental issues).

130 REPUBLICAN NAT'L COMM., supra note 19 , at 9 ("We reaffirm the Constitution's fundamental principles: limited government, separation of powers, individual liberty, and the rule of law.").

131 Hahn \& Stavins, supra note 129, at 12 ("Incentive-based schemes can promote environmental protection at a cost lower than that of command-and-control approaches. Incentive schemes can also improve the international competitiveness of U.S. industry because they offer huge savings and increases in productivity relative to command-and-control regulation.").

132 See generally Matthew J. Neidell, Air Pollution, Health, and Socio-Economic Status: The Effect of Outdoor Air Quality on Childhood Asthma, 23 J. HEALTH ECON. 1209 (2004) (linking air pollution levels to child hospitalizations for asthma).

133 Dallas Burtraw \& Sarah Jo Szambelen, U.S. Emissions Trading Markets for $\mathrm{SO}_{2}$ and NO 12-14 (Res. for the Future Discussion Paper No. 09-40, 2009) (reviewing the empirical literature on the effects of the incentive-based environmental regulation on innovation); Stewart, Regulation, Innovation and Administrative Law, supra note 73, at 1373 (arguing that incentive- 
the blowback on EPA and state-level DEPs that has resulted in these agencies being under constant scrutiny and pressure over the past several decades. ${ }^{134}$ More fundamentally, a system of harm charges promises to end the practice of significant levels of pollution being permitted (literally being authorized through permits issued by EPA or state regulatory bodies) for free under best available technology rules. Making polluters pay for every increment of harm will sharpen the incentive for reduced emissions ${ }^{135}$-and could become a powerful tool for those concerned about environmental justice, as the residual pollution risks in our society tend to affect disproportionately minority and disadvantaged communities. ${ }^{136}$

Ultimately, all Americans-both Republicans and Democrats-would come out ahead under an environmental regime that focuses on the biggest risks as a regime of price signals does. And in a world of competing demands on inevitably limited government budgets, everyone benefits by having whatever level of funds society commits to pollution control and natural resource management spent well. Ultimately, the greatest payoff of a pricesignal based regulatory framework is its spur to innovation, which offers the promise of new technologies or other breakthroughs that shift the environmental possibility frontier (EPF) inwards-translating into lower costs or reduced harm or some combination of both. ${ }^{137}$

based regulations are more effective at inducing innovation than command-and-control regulations).

134 E.g., Coral Davenport, E.P.A. Faces More Tasks, Louder Critics and a Shrinking Budget, N.Y. TIMES, Mar. 19, 2016, at A11.

135 Stewart, New Generation, supra note 73, at 99 (Market-based approaches "provide continuing incentives for innovation and investment in less polluting, more resource-efficient technologies. Sources that succeed in such innovation can reduce the price that they pay for residuals generated and thereby gain a competitive advantage, making environmental protection a profit center."). Notably, while command-and-control regulations have the theoretical potential to force radical technological change, they have struggled to do so in practice. Thomas O. McGarity, Radical Technology-Forcing in Environmental Regulation, 27 LOY. L.A. L. REv. 943, 945 (1994) (arguing that both the Clean Water Act and Clean Air Act encouraged, at best, incremental innovation in pollution-abatement technologies).

136 Importantly, pricing mechanisms must be designed to prevent the formation of pollution hotspots. See Daniel A. Farber, Pollution Markets and Social Equity: Analyzing the Fairness of Cap and Trade, 39 ECology L.Q. 1, 48 (2012) (cautioning that, while "cap and trade does not appear to have an intrinsic tendency to favor emissions reductions at cleaner plants as opposed to the dirtier plants that may more often exist in disadvantaged communities ..., if emissions trading does turn out to result in disproportionate levels of co-pollutants in disadvantaged communities, the regulator should be prepared to take appropriate action to address the situation and counteract that effect").

137 Daniel J. Dudek \& John Palmisano, Emissions Trading: Why Is This Thoroughbred Hobbled?, 13 Colum. J. ENvTL. L. 217, 234-36 (1988); David Popp, Innovation and Climate Policy, 2 ANN. REv. RESOURCE ECON. 275, 283 (2010) ("In general, market-based policies are thought to provide greater incentives for innovation, as they provide rewards for continuous improvement in environmental quality."). 


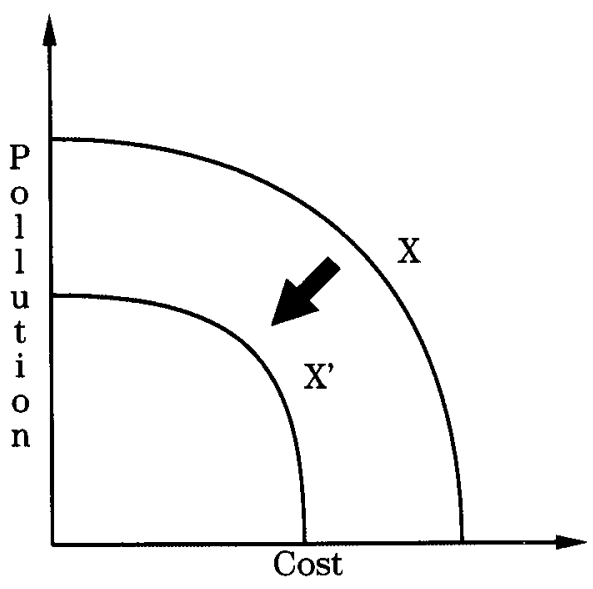

Figure 1: Environmental Possibility Frontier

The EPF captures the trade-off between pollution production and pollution control costs for a given level of technology. An inward shift of the EPF, which could be due either to a technological breakthrough or a reduction in regulatory burdens, allows the firm to reduce both pollution levels and control costs.

\section{B. Choice}

From a political point of view, the most critical step required for consensus on a new environmental strategy is clarity on the fact that reform need not mean more government dictates. As noted earlier, much of the perceived Republican hostility to climate change action is really opposition to Big Government solutions. ${ }^{138}$ In this regard, the shift from an environmental regime centered on command-and-control mandates to one focused on price signals could go a long way toward resolving the present political gulf. Market-based mechanisms by their very structure provide more choice.

But an emphasis on choice argues for a broader rethinking of the optimal government role in environmental protection for the 21st century. Rather than seeing their central (or even only) role to be that of regulators focused on setting mandatory standards, government officials might embrace an expanded vision of the pathways to sustainability-notably one where consumers, investors, and companies are recognized as points of leverage determining environmental outcomes.

In this regard, government should expand its focus on information disclosure. Highlighting good and bad performance often motivates behavioral change, even without regulatory reinforcement, as the Toxics

138 See discussion supra Part II.A. 
Release Inventory has demonstrated. ${ }^{199}$ Benchmarking and scorecards have expanded impact in today's highly transparent world in which the internet puts comparative performance results a click or two away. ${ }^{140}$

Much more can be done with environmental protection strategies that allow consumers as well as companies and investors to decide how much environmental protection to "buy." But good choices depend on good data and analysis. This argues for an expanded role for government in gathering and validating information and performance metrics, so as to enable market participants to be more confident in their choices and better positioned to make tradeoffs between environmental results and other virtues. ${ }^{141}$ Moving the government out of regulatory mode and into the role of information clearinghouse is particularly appropriate in circumstances where environmental impacts are internalized to the purchaser of a product or service. $^{142}$ It makes sense, for instance, for government to provide information in support of family decision making about what food to eat or which appliance to buy rather than mandating specific outcomes or sharply constraining choices. ${ }^{143}$

139 H. Spencer Banzhaf \& Randall P. Walsh, Do People Vote with Their Feet? An Empirical Test of Tiebout's Mechanism, 98 AM. ECON. REv. 843, 861-62 (2008) (concluding from empirical evidence that people move out of communities that report an increase in emissions from Toxics Release Inventory facilities); Shameek Konar \& Mark A. Cohen, Information as Regulation: The Effect of Community Right to Know Laws on Toxic Emissions, 32 J. ENvTL. ECON. \& MGMT. 109, 122 (1997) (providing empirical evidence that firms responded to Toxic Release Inventory disclosures by "significantly reduc[ing]" their toxic emissions); Ralph Mastromonaco, Do Environmental Right-To-Know Laws Affect Markets? Capitalization of Information in the Toxic Release Inventory, 71 J. ENVTL. ECON. \& MGMT. 54, 56 (2015) (finding that information in the Toxics Release Inventory affects housing prices, suggesting that consumers are aware of and respond to toxic chemical disclosures); David Weil et al., The Effectiveness of Regulatory Disclosure Policies, 25 J. Pol'Y ANALYSIS \& MGMT. 155, 171-72 (2006) (describing how Toxics Release Inventory requirements caused some major companies to alter their pollution prevention strategies, leading to declines in reported pollution releases).

140 Daniel C. Esty \& REece Rushing, CTr. For Am. Progress, Governing by the Numbers: The Promise of Data-Driven Policymaking in the Information Age 2 (2006), https://perma.cc/2XMD-KMZW (discussing how advancements in information technologies have reduced the costs of gathering, storing, analyzing, and disseminating information, thereby creating new opportunities for monitoring and comparing policy regimes); Daniel C. Esty, Measurement Matters: Toward Data-Driven Environmental Policymaking, in RouTLEDGe HANDBOOK ON SUSTAINABILITY INDICATORS (Simon Bell \& Steve Morse eds., forthcoming 2018) [hereinafter Esty, Measurement Matters] (highlighting the potential of data-driven comparative analysis to improve policy decision making across a diverse array of environmental issues and actors)

141 Energy Star, a voluntary labeling program, provides consumers with information on the energy efficiency of various products. The program has led to sizeable reductions of energy use in the United States. See Kenneth Gillingham et al., The Effectiveness and Cost of Energy Efficiency Programs, RESOURCES, Fall 2004, at 22, 24.

142 Nonprofits, for examples, have developed a wide array of eco-labels and sustainability accreditation programs that help direct sustainability-minded consumers to eco-friendly products. See Dan Vermeer et al., Corporate SustainabUity inttiative, an Overview of ECOLABELS AND SUSTAINABILITY CERTIFICATIONS IN THE GLOBAL MARKETPLACE 14 (Jay S. Golden ed., 2010).

143 For example, EPA's Energy Star program identifies for consumers energy efficient appliances. Gillingham et al., supra note 141 , at 23 . Also consider the Department of 
While a new environmental strategy that prioritizes choice would help bring the Right on board, the Left will need to be confident that the choices presented are meaningful ones with the potential for real benefits. In this regard, legitimate concerns-over whether the public is really positioned to make good choices and whether their economic circumstances preclude any real freedom to choose-will have to be addressed. ${ }^{144}$

\section{Interdependence and Integration: Systems Thinking}

One of the fundamental realities of the 21st century is that of interdependence and the need for a more integrated approach to environmental protection. ${ }^{145}$ Humanity depends on nature. But nature also depends on the choices of humans. Recent advances in science have begun to map the dense web of life on Earth from microscopic viruses to largescale ecosystems with all of their intricate connections. As Professor Oswald Schmitz observes, ecological science has revealed "how organisms fit together in communities through consumptive, competitive, and cooperative relationships with other organisms. It traces how those interdependent relationships influence... the ebb and flow of organisms and materials and energy across broad landscapes. ${ }^{146}$ Our legal framework has not been reconfigured with the implications of an interconnected world in mind. ${ }^{147}$

The powerful logic of sustainable development ${ }^{48}$ builds on the related understanding that ecological health and economic progress are deeply intertwined. ${ }^{149}$ Short-term material gains achieved at the cost of environmental degradation often lead to longer term economic challengesas China is now facing, ${ }^{150}$ and as the United State came to realize in the

Agriculture's Organic Certification program. Organic Labeling, U.S. DEP'T AGRIC., https://perma.cc/S6FX-RV38 (last visited Feb. 25, 2017).

144 For a discussion of the limitations of market-based regulations to environmental problems, see generally Frank Ackerman \& Kevin Gallagher, Getting the Prices Wrong: The Limits of Market-Based Environmental Policy (Global Dev. \& Env't Inst., Working Paper No. 0005, 2000).

145 Anastas, supra note 122, at 580-81 (encouraging EPA to adopt sustainability as a pillar of its research agenda).

146 OSWALD J. SCHMITZ, THE NEW ECOLOGY: RETHINKING A SCIENCE FOR THE ANTHROPOCENE, at ix (2017).

147 See, e.g., Barton H. Thompson, Jr., Defragging: Overcoming Fragmentation in United States Water Governance, in TRANS-JURISDICTIONAL WATER LAW AND GOVERNANCE 120 (Janice Gray et al. eds., 2016) (describing the negative consequences arising from severe fragmentation of the US water management system); see also Rose, supra note 57, at 293-94.

148 For a discussion of sustainable development, see JEFFreY D. SACHS, THE AGE of SUSTAINABLE DEVELOPMENT (2015).

149 A.J. McMichael, C.D. Butler \& Carl Folke, New Visions for Addressing Sustainability, 302 SCIENCE 1919, 1919 (2003); Bill Hopwood, Mary Mellor \& Geoff O'Brien, Sustainable Development: Mapping Different Approaches, 13 SustaINABle DEv. 38,39 (2005); SACHS, supra note 148 , at 1-14.

150 Jianguo Liu \& Jared Diamond, China's Environment in a Globalizing World, 435 NATURE 1179,1181 (2005) (noting that sustainability has featured prominently in China's national policies in recent years, but that the country continues to rank poorly on various sustainability metrics). 
$1960 \mathrm{~s} .{ }^{161}$ Environmental protection therefore requires a systems approach to problem solving that takes seriously the need for coordination across issues and political jurisdictions, and an integrated approach to energy, environment, and economic challenges. ${ }^{152}$

Many of the failures of our existing environmental programs arise from the silos of our 20th century legal framework and a systematic failure to set environmental goals in a context that takes competing policy virtues into account. As discussed above, this patchwork structure means that pollution gets shifted from one medium to another, standards are often set without regard to costs, and the incentives for regulatory efficiency are muted. ${ }^{163}$ Not only are environmental and economic considerations not balanced, but science and policy thinking are not integrated..$^{154}$ Nor is there coordination (which involves both cooperation and a degree of competition) among regulatory bodies-federal, state, and local-that share responsibility for environmental problem solving. ${ }^{165}$ Likewise, without a systems focus, the appropriate division of labor among public sector, private sector, and nonprofit entities in delivering of environmental programs does not get carefully considered. ${ }^{168}$

151 While estimates of the costs of air pollution to human and economic health in China. vary, nearly all conclude that the damages are substantial. See, e.g., KEITH CRANE \& ZHIMIN MAO, RAND CORP., COSTS OF SElECTED POLICIES TO ADDRESS AIR POLlUTION IN CHINA 3 (2015), https://perma.cc/LN4R-EFJG (finding that air pollution reduced China's gross domestic product (GDP) by about 6.5 percent annually between 2000 and 2010); GBD MAPS WORKING GRP., HEALTH EFFEcts Inst., BURden OF DISEASE ATTRIBUTABLE TO COAL-BURNING AND OTHER MAJOR SOURCES OF AIR POLLUTION IN CHINA 36 (2016), https://perma.cc/U8RD-GKDF (estimating that coal-burning alone contributed to an estimated 366,000 deaths in China in 2013); Kira Matus et al., Health Damages from Air Pollution in China, 22 Global ENvTL. Change 55, 60 tbl.5 (2012) (estimating that particulate matter cost China's economy $\$ 112$ billion in lost welfare in 2005); Robert A. Rohde \& Richard A. Muller, Air Pollution in China: Mapping of Concentrations and Sources, PLOS ONE, Aug. 20, 2015, e0135749, at 8 (estimating that Chinese air pollution contributes to approximately 1.6 million deaths per year).

152 See Andrew Jordan \& Andrea Lenschow, Environmental Policy Integration: A State of the Art Review, 20 ENVTL. POL'Y \& GOVERNANCE 147, 147 (2010) (discussing both the objectives and best practices of environmental policy integration (EPI), and identifying EPI as "an important first order principle to guide the transition to sustainability"); Thomas L. Adams Jr. \& M. Elizabeth Cox, The Environmental Shell Game and the Need for Codification, 20 Envtl. L. Rep. (Envtl. L. Inst.) 10,367, 10,368 (Sept. 1990) (calling on Congress to pass an integrated federal environmental code that would "unify congressional oversight, provide for cross-media regulation, and stimulate pollution prevention by industry")

153 See supra Part II.B.

154 See Joseph F.C. DiMento \& Helen Ingram, Science and Environmental Decision Making: The Potential Role of Environmental Impact Assessment in the Pursuit of Appropriate Information, 45 NAT. RESOURCES J. 283, 284-88 (2005) (describing a number of "divisions between science and environmental decision making").

155 See generally Daniel Esty \& Damien Geradin, Regulatory Co-opetition, 3 J. INT'L ECON. L. 235 (2000) (arguing that regulatory co-opetition-or a combination of competition and cooperation between government actors-will yield optimal governance results).

156 Cary Coglianese, Getting the Blend Right: Public-Private Partnerships in Risk Management 1-2 (Wharton Risk Mgmt. \& Decision Processes Ctr. Discussion Paper, 2015) (noting a growing interest among academics and policymakers in using public-private partnerships to "mak[e] progress in environmental protection and risk management"). 
Note that a systems perspective on pollution control and coherence across environmental programs is much easier to achieve using price signals rather than regulatory mandates. ${ }^{167}$ By their very structure, market mechanisms encourage attention to tradeoffs within the environmental arena and across other policy considerations, including cost. Because they are broad-gauge, outcome-oriented, and do not specify what technology must be deployed, a regime of harm charges encourages systems thinking, more comprehensive problem solving, and the adoption of new technologies as they become commercially viable. For example, the Clean Air Act's acid rain trading program generated huge savings because it allowed industry to use abatement options other than installing expensive scrubbers, including fuel blending. ${ }^{168}$ This broader perspective offers the promise of new and better ways of tackling energy and environmental challenges that get past the inability of the existing regime to balance competing goals, promote lowcost solutions, and encourage investment in required infrastructure.

\section{Innovation and Green Lights}

We live in an age of extraordinary progress in all realms of knowledge, with particularly strong progress being achieved in the technology arena. The gains made possible by the tools of the Information Age (discussed in detail in Part $\mathrm{V}$ below) promise to deliver further advances in many domains that could contribute to improved environmental public health and ecosystem vitality. ${ }^{169}$ This reality argues for a structure of environmental law that promotes ongoing inquiry, regular updating of the scientific foundations for policy, and breakthroughs in technology. ${ }^{100}$ Our legal framework should be designed to spur rather than chill innovation-sharpening the incentives for problem solving and investment in creative solutions.

The requisite green lights can take many forms. ${ }^{161}$ Not all of the details about how the structure of environmental law should be recast to drive this

157 Dudek \& Palmisano, supra note 137, at 222.

158 Curtis Carlson et al., Sulfur Dioxide Control by Electric Utilities: What Are the Gains from Trade?, 108 J. POL. ECON. 1292, 1316-17 (2000).

159 Manuel CASTELLS, THE RISE OF THE NETwORK SOCIETY, at xviii, xxv-xxvi (2d ed. 2010) (arguing that advancements in information technologies during the 1990s ushered in a new age for humanity, the Information Age); JAMES A. DEWAR, RAND CORP., THE INFORMATION AGE AND THE PRINTING PRESS: LOOKING BACKWARD to SEE AHEAD 2-3 (1998), https://perma.cc/XR55-Q7B4 (discussing technological innovation in the information age).

160 Arthur P.J. Mol, Environmental Governance in the Informational Age: The Emergence of Informational Governance, 24 ENVTL. \& PLAN. C 497, 501, 507-11 (2006) (outlining the potential of new information and communication technologies to revolutionize environmental governance).

161 For a precursor to this green lights strategy, see E. Donald Elliot, Environmental TQM: $A$ Pollution Control Program that Works!, 92 MiCH. L. REv. 1840, 1844, 1849-50 (1994) (contrasting "government standard setting through legalistic bureaucracy" with "private pollution programs described in the PCEQ-TQM Report", which-among other things-provided "positive reinforcement for desirable corporate conduct through public recognition"). 
priority on innovation have been worked out yet. ${ }^{162}$ But there is learning to build upon. For example, just as Calabresi and Melamed highlighted the value of placing liability on the lowest-cost risk avoider as a way to sharpen incentives for care, ${ }^{163}$ we now would benefit from a legal framework that induces those best positioned to deliver environmental breakthroughs to take up the innovation charge.

One dimension of the challenge relates to data and analysis-and the need to reduce the scope of uncertainty in environmental decision making. ${ }^{164}$ In this regard, the lowest-cost information generators should be incentivized to fill data and analysis gaps. ${ }^{165}$ Examples of how this might work already exist. For instance, Prop 65 in California ${ }^{166}$ and the EU's Registration, Evaluation, Authorization, and Restriction of Chemicals (REACH) ${ }^{167}$ regimes of chemical regulation shift the burden of proof concerning safety-and in doing so, induce companies producing products containing chemicals to put forward much more detailed information about environmental risks. In the context of a government focus on pricing harms, one could achieve the same burden shift by resolving uncertainties against the low-cost information provider.

From breakthroughs in solar power, batteries and electricity storage, electric vehicles, and clean technology more broadly, better ways of doing things have begun to emerge on many fronts. ${ }^{168}$ The marriage of digital technologies to environmental challenges has only just begun. ${ }^{169}$

162 Timothy J. Foxon et al., Innovation in Energy Systems: Learning from Economic, Institutional and Management Approaches, in INNOVATION FOR A LOW CARBON ECONOMY: ECONOMIC, InSTITUTIONAL AND MANAGEMENT APPROACHEs 1, 9-11 (Timothy J. Foxon et al. eds., 2008) (underscoring the importance of innovation to addressing climate change).

163 Guido Calabresi \& A. Douglas Melamed, Property Rules, Liability Rules, and Inalienability: One View of the Cathedral, 85 HARV. L. REv. 1089, 1127 (1972).

164 Notably, many of the challenges to effective environmental data collection and monitoring are institutional, rather than technical, in nature. See Eric Biber, The Challenge of Collecting and Using Environmental Monitoring, 18 ECOLOGY \& SoC'Y, no. 4, 2013, at 68, 68 (explaining how "ambient monitoring is difficult to conduct effectively, and that difficulty creates political, legal, and organizational obstacles to the collection and use of monitoring data. Solutions require understanding why and how those obstacles deter the collection and use of ambient monitoring data.").

165 See generally Christine J. Kirchhoff, Maria Carmen Lemos \& Suraje Dessai, Actionable Knowledge for Environmental Decision Making: Broadening the Usability of Climate Science, 38 ANN. REV. ENVTL. \& RESOURCES 393 (2013) (underscoring the under-utilization of scientific knowledge in environmental decision making).

166 James C. Cooper, Proposition 65 and the Proposed California Right to Know Genetically Engineered Foods Act: A Comparison of Litigation Incentives 2, 10 (2012) (unpublished manuscript), https://perma.cc/Y6US-3KPX (describing how Proposition 65 is designed to increase the amount of information available to consumers).

167 For a comprehensive overview of REACH regulation, see generally Adam D.K Abelkop \& John D. Graham, Regulation of Chemical Risks: Lessons for Reform of the Toxic Substances Control Act from Canada and the European Union, 32 PACE ENvTL. L. REv. 108, 151-68 (2015). The Frank R. Lautenberg Chemical Safety for the 21st Century Act, Pub. L. No. 114-182, 130 Stat. 448 (2016), effectuates a similar shift for the United States through reforms to the Toxic Substance Control Act, 15 U.S.C. 2601-2692 (2012), but in a less clear manner.

168 These breakthroughs are evidenced by the rapidly declining cost of solar, wind, and battery storage. CAMLlA STARK ET AL., NAT'L RENEWABLE ENERGY LAB, NREL/TP-6A50-63604, 
The application of breakthroughs from adjacent disciplines into the environmental domain could be transformative. Recent progress in genomics, for instance, makes it clear that individual susceptibility to harms varies-and that how harms manifest themselves are usually a function of a complex interaction of factors. ${ }^{170}$ In a similar vein, gene editing and other advances in biotechnology could strengthen our ability to respond to some of the most pressing threats to nature and humanity. ${ }^{171}$ In the not-too-distant future, it may be possible to edit the genetic code of ash trees to allow them to resist the Emerald Ash borer. ${ }^{172}$ And trees more generally might be recoded to take up more carbon dioxide as a way to combat climate change ${ }^{173}$ Similar breakthroughs could transform our approach to pollution control-for instance, enabling faster bioremediation of toxic waste sites or chemical spills. ${ }^{174}$ As noted earlier, to encourage this sort of work, a more carefully structured set of incentives needs to be in place-encouraging those doing basic research to translate their discoveries into environmental technologies, policies, and strategies. ${ }^{176}$

America needs a broad-gauge innovation strategy designed to promote breakthroughs in the many spheres that could contribute to environmental progress. But the innovation emphasis must go beyond technology development. It should also encompass creative finance mechanisms to promote greater, wider, and deeper investments in pollution control, land conservation and biodiversity, energy efficiency and renewable power, and the infrastructure required to make all of society's critical systemstransportation, agriculture, production, etc.-more sustainable. ${ }^{176}$ Likewise,

RENEWABLE ELECTRICITY: INSIGHTS FOR THE COMING DECADE, at v-vi (2015); RAN FU ET AL., NAT'L RENewable ENERgy LAB., NREL/TP-6A20-66532, U.S. SOLAR Photovoltaic System COST BenchmarK: Q1 2016, at 1 (2016); Tom Randall, Wind and Solar Are Crushing Fossil Fuels, BLOOMBERG (Apr. 6, 2016), https://perma.cc/S6PV-5N4R.

169 See generally ARTHUR P.J. MOL, ENVIRONMENTAL REForm in the INFormation AGE: THE CONTOURS OF INFORMATIONAL GOVERNANCE 19 (2008); Braden R. Allenby, et al., Information Systems and the Environment: Overview and Perspectives, in INFORMATION SYSTEMS AND THE ENVIRONMENT 1, 2-10 (Deanna J. Richards et al. eds., 2002) (reviewing how advancements in information technology have created new opportunities to improve environmental performance); Esty, Information Age, supra note 127, at 117-20 (detailing the potential of information technologies to revolutionize environmental regulation and protection).

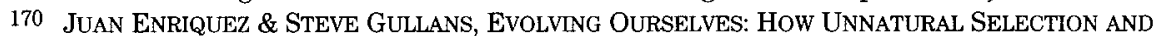
NONRANDOM MUTATION ARE CHANGING LIFE ON EARTH 69-70, 117 (2015).

171 U.N. Framework ConvENTION ON Climate Change, TEChNologies for adaPTATION to Climate Change 9 (2006) (identifying biotechnology as a potential strategy for adapting agriculture to global warming) https://perma.cc/98TP-KPJR.

172 Genetically Modified Trees: Into the Wildwood, EConomist, May 4, 2013, at 78.

173 Christer Jansson et al., Phytosequestration: Carbon Biosequestration by Plants and the Prospects of Genetic Engineering, 60 BIOSCIENCE 685, 694 (2010) (estimating that genetically modified trees and plants could sequester billions of tons of carbon dioxide annually).

174 See, e.g., Ronald M. Atlas \& Terry C. Hazen, Oil Biodegradation and Bioremediation: A Tale of the Two Worst Spills in U.S. History, 45 ENVTL. SCI. \& TECH. 6709, 6711 (2011); Gary S. Sayler \& Steven Ripp, Field Applications of Genetically Engineered Microorganisms for Bioremediation Processes, 11 CURRENT OPINION BIOTECHNOLOGY 286, 288 (2000).

175 See supra Part III.D.

176 See generally Richard L. Ottinger \& John Bowie, Innovative Financing for Renewable Energy, 32 PACE ENVTL. L. REv. 701 (2015) (discussing successful new finance mechanisms for 
innovation in public engagement on these issues and in new partnerships to deliver better results would also be useful. ${ }^{177}$

\section{GOVERNANCE FOR A 21ST CENTURY SUSTAINABHITY STRATEGY}

Translating these core sustainability principles into action will require a new governance framework. While our 20th century environmental regime centered on federal government regulation, the 21 st century sustainability strategy I envision would reassign primary environmental protection responsibilities across a broader spectrum that spans from international institutions to individual households. ${ }^{178}$ To accommodate and coordinate these many different actors, the 21st century governance structure for sustainability must be more flexible and more adaptive than its 20th century counterpart. It must also do a better job at integrating decision making across environmental issues, since reconfiguring our legal framework to account for the interdependencies of pollution spillovers can only occur if government actors and agencies break out of the media-specific mindset that has dominated environmental law until now. This horizontal restructuring of decision making must, in turn, be accompanied by a vertical restructuring of environmental regulatory authority across the levels of government. As I will argue below, a reinvigorated commitment to environmental federalism is critical to effectuating the foundational principles undergirding my 21 st century sustainability strategy.

\section{A. Going Beyond Government-Centered Environmental Protection}

20th century environmental policy largely focused on governments telling the business community and, to some extent, individuals what they could not do. It was a world of red lights. ${ }^{179}$ In 1970 , the need to focus on stopping harm-causing behavior seemed obvious. From Cleveland's Cuyahoga River catching fire to the toxic waste and human health crisis of

renewable energy sources); J.B. Ruhl \& James Salzman, The Law and Policy Beginnings of Ecosystem Services, 22 J. LAND USE \& ENVTL. L. 157 (2007) (discussing conservation finance mechanisms); Michael B. Gerrard, Introduction and Overview, in THE LAW OF CLEAN ENERGY: ENERGY EFFICIENCY AND RENEWABLES 1, 14-17 (Michael .B. Gerrard ed., 2011) (reviewing innovative finance mechanisms for renewables and energy efficiency resources).

177 See Manjyot Bhan, The Role of Public-Private Partnerships in U.S. Environmental Policy: Case of the EPA and the U.S. Semiconductor Industry, 11 PUB. PURPOSE 49, 49 (2013) (noting that the roles of government, the private sector, and nongovernmental actors are in the process of being redefined).

178 This proposal echoes and builds upon earlier calls for expanding the pool of actors responsible for environmental decision making. See, e.g., Vandenbergh, Reconceptualizing, supra note 16, at 390 (arguing for a reframing of environmental governance that moves away from government-only decision making to include a broader range of private actors).

179 See Rose, supra note 57, at 276-77 (describing the first wave of major environmental regulations as "behavior-based" regulations that "constrained the actions of resource-users"); see also Carol M. Rose, Rethinking Environmental Controls: Management Strategies for Common Resources, 1991 DUKE L.J. 1, 8-10 (1991) (laying out four core "controls" for managing shared resources). 
Love Canal, the problems seemed obvious-and so did the solutions. ${ }^{180}$ The public demanded action. ${ }^{181}$ The details seemed not to matter. Governmentdefined solutions (regulatory commands) seemed like the best path forward. ${ }^{182}$

But today, we know that red lights are not enough. Limiting or even forbidding pollution is not the same as solving environmental problems. ${ }^{183}$ Just as a traffic intersection needs green lights as well as red ones to optimize the flow of vehicles, our environmental protection system must be understood to encompass more than the regulatory regime and more than red lights. To reinvigorate a focus on innovation, our environmental law framework should be rethought with an eye on creating broader structure of incentives for problem solving above and beyond any prices, penalties, or prohibitions on harm causing.

The 20th century environmental protection model did, of course, induce some investment in the development of pollution controls. ${ }^{184}$ An extensive literature had emerged around the idea of "technology forcing" laws. ${ }^{185}$ But the investments in innovation in recent decades have been spotty at best and demonstrably insufficient in a number of critical areas including, most notably, the need for low-cost renewable electric power ${ }^{186}$ Indeed, electricity comes today from largely the same sources as a century ago and its

180 Daniel A. Farber, Politics and Procedure in Environmental Law, 8 J.L. ECON. \& ORg. 59, 67 (1992) (describing Love Canal, Three Mile Island, and other environmental disasters as catalyzing public support for environmental legislation in the 1970s); Richard J. Lazarus, $A$ Different Kind of "Republican Moment" in Environmental Law, 87 MINN. L. REv. 999, 999-1000 n.3 (2003) (noting legislative responses to the burning of the Cuyahoga River and the Exxon Valdez oil spill); see also RICHARD N.L. ANDREWS, MANAGING THE ENVIRONMENT, MANAGING OuRselves: A History of AMERICAN EnviRonmental POLICY 202-03 (2d ed. 2006) (discussing how dramatic and well publicized environmental disasters led to "an unprecedented outpouring of national regulatory policies to preserve and protect nature and reduce pollution" in the 1970s).

181 Farber, supra note 180, at 67.

182 ANDREWS, supra note 180, at 227-55.

183 Consider, for example, the cross-media leakage of pollution, as discussed earlier. See supra notes 56-58 and accompanying text.

184 See, e.g., Ayres \& Kapczynski, supra note 73, at 1815-16 (discussing how National Highway Traffic Safety Administration's CAFE program led to technological advancements in vehicle fuel efficiency).

185 See generally D. Bruce La Pierre, Technology-Forcing and Federal Environmental Protection Statutes, 62 IOWA L. REv. 771 (1977) (describing the technology forcing attributes of the major environmental statutes from the 1970s). See also Adam B. Jaffe, Richard G. Newell \& Robert N. Stavins, Environmental Policy and Technological Change, 22 ENVTL. \& RESOURCE ECON. 41, 50 (discussing some of the design flaws embedded in technology forcing mandates); Stewart, Regulation, Innovation and Administrative Law, supra note 73, at 1259-60 (noting the limitations and inefficiencies of forcing technology with inflexible command-and-control regulatory regimes); Stewart, New Generation, supra note 73, at 21 (summarizing the defenses and criticisms of technology-forcing regulatory mandates).

186 INT'L ENERGY AGENCY, WORLD ENERGY INVESTMENT OUTLOOK 44 (2014) (estimating that, in order to head off the worst effects of climate change, global annual investments in low-carbon technologies will need to be twice as large in 2020 and six times as large in 2035 as compared to 2013 levels). 
distribution across wires strung over utility poles is virtually unchanged in a hundred years. ${ }^{187}$

Incentives do exist to promote private-sector focus on energy and environmental problems. Tax credits are available to induce investments in wind and solar power. ${ }^{188}$ Huge subsidies have been provided to corn farmers and those producing ethanol as an alternative transportation fuel. ${ }^{189}$ But these green lights represent a haphazard framework of incentives that often deliver very little in the way of on-the-ground results. Indeed, American taxpayers have provided tens of billion dollars in subsidies over the past twenty years for corn-based ethanol with little to show for this massive investment. ${ }^{190}$

What is needed is a careful rethinking of the structure of incentives and how best to induce investments in environmental progress. Extensive scholarly work is being done on how best to change behavior. From "nudges" to default rules, new learning from psychology, anthropology, and behavioral economics has cast a spotlight on how best to deliver changed outcomes. ${ }^{191}$ For example, experimental evidence suggests that people are less likely to enroll in clean electricity programs if they must "opt in" to the program than if they are automatically enrolled in the program with the

187 Katherine Tweed, NRG's David Crane Warns of 'Shockingly Stupid' Planning in the Power Sector, GREENTECH MEDIA (Feb. 25, 2014), https://perma.cc/UDP3-6P53 ("Think how shockingly stupid it is to build a 21st-century electric system based on 120 million wooden poles .... You can strengthen the system all you want, but if you accept that we're in the first stage of adaptation, the system from the 1930s isn't going to work in the long term." (quoting David Crane, former CEO of NRG Energy, Inc.)); see also Letter from David Crane, Chief Exec. Officer, NRG Energy, Inc., to Shareholders (2014), reprinted in David Crane, NRG's David Crane: Where is the Amazon, Apple and Google of the Utility Sector?, GREENTECH MEDIA (Mar. 27, 2014), https://perma.cc/J25P-XKTZ (laying out Crane's vision for a clean energy future based on fundamental transformation of our sources and distribution of electricity supply).

188 See generally TrIeU MAI ET AL., NAT'L RENEWABLE ENERgY LAB., NREL/TP-6A20-65571, IMPACTS OF FEDERAL TAX CREDIT EXTENSIONS ON RENEWABLE DEPLOYMENT AND POWER SECTOR EMISSIONS 13-18 (2016) (finding that extensions of the renewable energy tax credits in 2016 will have substantial effects on wind and solar capacity).

189 Zachary M. Wallen, Note, Far From A Can of Corn: A Case for Reforming Ethanol Policy, 52 ARIZ. L. REV. 129, 134-39 (2010) (detailing history of U.S. ethanol subsidy program).

190 Between 1979 and 2000, the ethanol industry received more than $\$ 10$ billion in tax incentives alone. Robert W. Hahn, Ethanol: Law, Economics, and Politics, 19 STAN. L. \& PoL'Y REv. 434, 440 (2008). Including all federal and state programs, annual ethanol subsidies totaled to $\$ 5-7$ billion in 2006. Id at 439 . Many studies have found that the costs of subsidization exceed the benefits of ethanol. See, e.g., $i d$. at 460 (finding that costs exceed benefits by about $\$ 3$ billion annually).

191 See generally RICHaRd H. THALER \& CASS R. Sunstein, Nudge: IMProving DECISIONS ABOUT HEALTH, WEALTH, AND HAPPINESS (2008). (arguing that changes in the way options are presented can significantly alter behavioral outcomes). See also Cass R. Sunstein \& Lucia A. Reisch, Automatically Green: Behavioral Economics and Environmental Protection, 38 HARV. ENVTL. L. REV. 127, 128 (2014) (arguing that green default rules may be more effective at altering behavior than large economic incentives); Vladas Griskevicius, Joshua M. Tybur \& Bram Van den Bergh, Going Green to Be Seen: Status, Reputation, and Conspicuous Conservation, $98 \mathrm{~J}$. PERsonAlity \& Soc. Psychol. 392, 392 (2010) (arguing that the attractiveness of some green products, such as the Prius, to consumers lies in their status signal); Rachel Croson \& Nicolas Treich, Behavioral Environmental Economics: Promises and Challenges, 58 ENVTL. RESOURCE ECON. 335, 336 (2014) (reviewing extant literature on behavioral environmental economics). 
option of opting out. ${ }^{192}$ But this thinking has not yet been systematically translated into an optimized framework in support of a sustainable future. ${ }^{193}$

While the details of the full structure of green lights will need to be worked out in the years ahead, what is clear already is that the pace and scale of environmental progress can be lifted through a sustainability strategy that reconceptualizes the framework for environmental progress. A broader sustainability strategy would seek to expand the array of players on the environmental stage. It would include incentives to engage individuals, communities, industrial companies and other producers, banks, capital markets, insurance providers, nongovernmental organizations (NGOs), and more. Yet the commitment to a more diverse set of drivers of environmental progress does not mean that government is banished from the stage. To the contrary, the government role will remain critical but transformed-focused on efforts to induce rather than direct environmental activities and investments.

As environmental protection evolves from a one-man show to a large cast, the 21st century governance structure will need to encompass more than the EPA-drawing in other departments at the federal level, state and local agencies, international organizations, and standard-setting bodies such as the Securities and Exchange Commission (SEC) and the Federal Accounting Standards Board (in support of structured reporting of sustainability metrics) as discussed more fully in Part V.C below. At the same time as this broader base of technocratic expertise is drawn into the environmental protection process, structures must be put in place both to insulate these officials from special interests (particularly the distortions of big money) and to encourage political accountability. ${ }^{194}$

\section{B. Integration: Toward a Systems Approach to Environmental Issues}

America's prospects for a prosperous economy and a flourishing natural environment depend on finding ways to work across issues in a much more integrated way. ${ }^{105}$ Pollution offers a particularly challenging

192 Cass R. Sunstein, Deciding by Default, 162 U. PA. L. REv. 1, 3-4 (2013). While default rules have shown huge potential in increasing enrollment in environmental programs, there may be instances where such rules will trigger resentment over perceived restrictions on personal freedom. In these instances, active choice programs-where individuals are required or encouraged to pick between environmentally friendly and nonenvironmentally friendly options-may be optimal. Simon Hedlin \& Cass R. Sunstein, Does Active Choosing Promote Green Energy Use? Experimental Evidence, 43 ECOLOGY L.Q. 107, 111-12 (2016).

193 See generally John M. Gowdy, Behavioral Economics and Climate Change Policy, $68 \mathrm{~J}$. ECON. BEHAVIOR \& ORG. 632 (2008) (arguing for greater integration of behavioral economics into the policy framework).

194 See generally Susan Rose-Ackerman, Citizens and Technocrats: An Essay on Trust, Public Participation, and Government Legitimacy, in COMPARATTVE ADMINISTRATIVE LAW (Susan Rose-Ackerman \& Peter L. Lindseth eds., 2d ed. forthcoming Aug. 2017); see also David Schleicher, City Unplanning, 122 YALE L.J. 1670 (2013) (demonstrating how public choice problems-especially the intense preferences of some residents-distorts decision making in the city planning and zoning context).

195 See generally Rose, supra note 57. 
policy problem because of the wide range of emissions sources, the ease with which these streams mix together into an undifferentiated "soup," the diverse set of human and natural impacts that arise, and the stubborn unwillingness of pollution to abide by political boundaries. This physical reality makes a systems approach to environmental decision making, and thus governance, essential. ${ }^{106}$

A commitment to systems thinking means breaking down the silos of the 20th century in which media-specific laws (separate statutes for air, water, waste, land, etc.) dominated instead of a unified pollution control framework. ${ }^{197}$ It argues not only for a cross-media perspective, but also for economy-wide regulatory strategies rather than sector-specific approaches. This principle would suggest, for example, that a broad-based carbon charge offers a better game plan for greenhouse gas emissions control than an electric-generating-sector-focused regime, such as the Obama administration put forward with its Clean Power Plan. ${ }^{198}$

It also requires recognizing trade-offs and the need to balance competing goals that the 20th century legal regime often seems to elide or hide. Not only must the full portfolio of environmental risks be understood and factored in to decisions, but even more fundamentally, the cost of regulation cannot be ignored. The shift to a regulatory regime of price signals should help in this regard by reducing the need for governments to do the balancing of costs and benefits. ${ }^{199}$ Once the schedule of harm charges is set-and if it is set at the right level-the polluting entities will make the choice about how far to push their emissions control efforts and how to balance the cost of additional control with the fees to be paid for emissions that remain. ${ }^{200}$

196 Guruswamy, supra note 59, at 46 (arguing that an integrated pollution control approach is necessary to manage the "synergistic and cross-media effects of such pollution").

197 Adams \& Cox, supra note 152, at 10,368 (noting that "the media-specific framework allows companies to generate pollution in one media to avoid compliance with regulatory standards in another").

198 Timothy J. Brennan, Will the Clean Power Plan Reduce the Prospects for a Carbon Tax, RESOURCES FOR FUTURE: COMMON RESOURCES BLOG (Dec. 4, 2015), https://perma.cc/59BC-84CT (noting that a general carbon tax would be preferred over the Clean Power Plan because it would apply economy wide, not just to the electricity grid).

199 Winston Harrington \& Richard D. Morgenstern, Economic Incentives versus Command and Control: What's the Best Approach for Solving Environmental Problems?, RESOURCES, Fall/Winter 2004, at 13, 17. Of course, governments would still need to be involved in setting the levels of harm charges, as such determinations often involve technical, political, and ethical judgments. See, e.g., William Pizer et al., Using and Improving the Social Cost of Carbon, 346 SCIENCE 1189, 1189-90 (2014) (describing the difficult analytic and ethical choices that must be made in order to construct an appropriate measure of the cost of carbon, and advocating for a formal institutional process by which the U.S. government can update its estimates of the social cost of carbon).

200 Carlson et al., supra note 158, at 1295 (finding that the 1990 Clean Air Act $\mathrm{SO}_{2}$ emissions trading program reduced regulatory costs by $\$ 700-\$ 800$ million per year as compared to welldesigned command-and-control programs). 
Of course, government authorities will still have a critical role to play in setting and refining the harm charges. ${ }^{201}$ Underpinning the "price" placed on pollution harms must be a commitment to good data, careful analysis, cutting-edge science, thoughtful risk assessment, and rigorous benefit-cost calculations. ${ }^{202}$ The advances in data, science, and analysis outlined in Part V.A should help to ensure that the protocol for setting prices yields results that reflect the best underlying information from the fields of epidemiology, ecology, economics, and more. Better science should also reduce uncertainties, ${ }^{203}$ narrowing the need for assumptions and the zone over which political judgment is required. ${ }^{204}$ Thus, better analytics and the shift to price setting should reduce the scope for partisan dispute in the regulatory process. $^{205}$

Likewise, in our data-rich world, where the role of government has already been recast to include framing information for easier access by individuals and families, more decisions can be shifted to the household scale as noted above. ${ }^{206}$ As a matter of principle, whenever the scope of

201 For example, intergenerational discounting plays a pivotal role in determining the social cost of carbon, but determining what discount factor to apply implicates complex ethical and political questions that cannot be resolved by science alone. See Douglas A. Kysar, Discounting. . . On Stilts, 74 U. CHI. L. REV. 119, 136 (2007) (arguing that discounting conflates "the fundamental issues of intergenerational equity... with the issue of intergenerational efficiency."); Richard L. Revesz \& Matthew R. Shahabian, Climate Change and Future Generations, 84 S. CAL. L. REv. 1097, 1162 (2011) (arguing that "we cannot simply reduce all of our ethical qualms to the choice of a discount rate and then mechanically discount future benefits of climate change mitigation at the market rate of return," but instead must grapple with "what is truly at stake: what obligations we owe to future generations to mitigate climate change").

202 Notably, the environmental community has come a long way in their views on and acceptance of cost-benefit analysis. Michael A. Livermore \& Richard L. Revesz, Interest Groups and Environmental Policy: Inconsistent Positions and Missed Opportunities, 45 ENVTL. L. 1, 2-4 (2015) (documenting how environmental groups evolved from strongly opposing the use of cost-benefit analysis for environmental policy to becoming more enthusiastic about the tool).

203 See generally Gernot Wagner \& Martin L. WeItzman, Climate Shock: The Economic CONSEQUENCES OF A HOTTER PLANET 48-79 (2015). Of course, any good price system will require refinements over time to account for unforeseen circumstances or on-the-ground changes. For example, the European Union's Emission Trading Scheme initially struggled because it had not adequately anticipated the effects of a severe recession on the market for carbon emissions. Arthur Nelson, EU Agrees to Landmark' Carbon Market Deal, GuARDIAN (London) (May 6, 2015), https://perma.cc/66AS-CALY.

204 See Daniel C. Esty, Toward Optimal Environmental Governance, 74 N.Y.U. L. REv. 1495, 1498 (1999) [hereinafter Esty, Optimal Governance] (noting that information failures lead to suboptimal environmental governance and underscoring the promise of the Information Age at filling in informational gaps); NovECK, supra note 113, at 100-01 (highlighting how data can generate better governmental decision making).

205 See Ted Gayer \& John K. Horowitz, Market-Based Approaches to Environmental Regulation, 1 Found. \& TRENDS MICROECONOMICS 201, 215 (2005) (arguing that a pollution pricing and cap-and-trade systems would engender fewer law suits than command-and-control regulations).

206 For example, technological advancements in smart grid technologies have made realtime electricity pricing (i.e., dynamic pricing) a real possibility, thereby giving consumers more control over their monthly electricity bills. See Paul L. Joskow \& Catherine D. Wolfram, Dynamic Pricing of Electricity, 102 AM. ECON. REV. (PAPERS \& PROC.) 381, 382 (2012). 
externalities is limited to impacts on those consuming a product, individual choice should be the watchword. Government should ensure that such choices are well-informed and that products meet basic safety thresholds, but need not dictate actual buying patterns. ${ }^{207}$ More broadly, an emphasis on fewer government commands and more individual, family, and business choice would go a long way toward creating a political setting in which Republicans as well as Democrats would be willing to talk about transformative change.

\section{Reinvigorated Environmental Federalism}

The principle of integration needs to extend to our regulatory regime, arguing for vertical as well as horizontal restructuring of our system of environmental protection. ${ }^{208}$ It demands a reinvigorated environmental federalism that redistributes responsibilities across local, state, federal, and global officials with new emphasis on (what Europeans call) subsidiarity ${ }^{209}$ and a recognition that these various levels of governance need to engage in a degree of "co-opetition." ${ }^{210}$ This would mean that multiple levels of government should cooperate in many circumstances and work closely together for optimal goal setting and implementation of environmental programs. ${ }^{211}$ But they should also provide checks and balances on each other-ensuring that policy failure at one level can be compensated for at

207 Examples of this approach include state GMO labeling laws, the Department of Energy's Energy Star labeling program for energy efficient products, and the USDA Certified Organic labels-to name a few. Stephanie Strom, G.M.O.s in Food? Vermonters Will Know, and So May You, N.Y. TImes, July 2, 2016, at B3; David Wigder, Eco-Labels Impact Consumer Behavior, GREENBIZ (May 23, 2008), https://perma.cc/94DK-FLT9.

208 Esty, Optimal Governance, supra note 204 at, 1556-67 (1999) (discussing the need for cooperation and competition among entities along horizontal and vertical axes); see also Jody Freeman \& Daniel A. Farber, Modular Environmental Regulation, 54 DUKE L.J. 795, 797 (2005) ("There is rarely a single tool, or a lone agency at either the federal or state level, that is capable of producing the desired environmental benefit by itself, especially now that the most easily captured environmental gains have been obtained through the first wave of regulation.").

209 Josephine van Zeben, Subsidiarity in European Environmental Law: A Competence Allocation Approach, 38 HARv. ENVTL. L. REv. 415, 416 (2014) (“'Subsidiarity] may generally be defined as prescribing a division of competence where 'central authority should have a subsidiary function' and perform 'only those tasks which cannot be performed at a more local level.").

210 See generally Esty \& Geradin, supra note 155 (arguing that regulatory co-opetition-or a combination of competition and cooperation between government actors-will yield optimal governance results).

211 For example, John Nolon shows the potential of local government decision making on conservation and sustainable development to help mitigate climate change, provided local decision makers are "properly assisted by the federal and state governments." John R. Nolon, Land Use for Energy Conservation and Sustainable Development: $A$ New Path Toward Climate Change Mitigation, 27 J. LAND USE \& ENVTL. L. 295, 296 (2012); see also Kaush Arha \& Barton H. Thompson, Jr., Toward Greater State and Local Commitment, in THE ENDANGERED SPECIES ACT and Federalism: EFFective Conservation through Greater STATE CoMmITMENT 307 (Kaush Arha \& Barton H. Thompson, Jr. eds., 2011) (arguing that the United States could provide better protection of endangered and threatened species by devolving certain authorities to the states). 
another. ${ }^{212}$ In addition, a degree of competition among mayors, governors, federal officials (both elected and appointed) as well as international organization representatives can spur policy innovation and fresh thinking about how best to address persistent and difficult problems. ${ }^{213}$

Fundamentally, we need a new regulatory division of labor that tracks the "matching principle," meaning that it assigns primary responsibility on an issue-by-issue basis to the most decentralized level of decision making that matches the extent of the problem at hand, thus ensuring the greatest degree of accountability but avoiding the risk of under-attended-to externalities that extend beyond the jurisdiction of the governing entity. ${ }^{214}$

Problems that inescapably transcend national boundaries, such as climate change, require some degree of international collaboration. ${ }^{215}$ Protecting the shared spaces of the global commons cannot be done on a nation-by-nation basis insofar as spillovers of harm from one country to another are too likely to be ignored. ${ }^{216}$ The 2015 Paris Climate Change Agreement and the United Nations' new Sustainable Development Goals (SDGs) represent major breakthroughs in collaboration at the international scale. The SDGs provide an agreed-upon set of seventeen policy priorities for the next fifteen years. ${ }^{217}$ Taken as a whole, the SDGs package makes clear the need for an integrated perspective on environmental, social, and economic challenges under a "sustainable development" framework. ${ }^{218}$ The 2015 Climate Change Agreement also represents a watershed in policy integration, with its shift from a top-down approach to greenhouse gas emissions control based on "targets and timetables" to a bottom-up

212 See, e.g., Esty \& Geradin, supra note 155, at 250 (observing that the failure of Europe's southern Member States to engage in governmental environmental activity was corrected by regulations at the EU level); John R. Nolon, In Praise of Parochialism: The Advent of Local Environmental Law, 26 HARV. ENVTL. L. REV. 365, 365-66 (2002) (arguing that local governments should be "full partners of the state and federal governments in the critical matter of environmental protection" and noting in particular the local government well situated to address nonpoint source pollution, which the federal government has struggled to regulate).

213 Esty \& Geradin, supra note 155, at 254-55.

214 Id. at 240.

215 Robert O. Keohane \& David G. Victor, Cooperation and Discord in Global Climate Policy, 6 NATURE CIIMATE CHANGE 570, 570 (2016) ("Effective mitigation of climate change will require deep international cooperation."); see also Daniel A. Farber, Carbon Leakage Versus Policy Diffusion: The Perils and Promise of Subglobal Climate Action, 13 CHI. J. INT'L L. 359, 360 (2012) (observing that "[c]limate change is a global problem that will ultimately require a concerted global response," but arguing that subglobal efforts can help build towards global cooperation).

216 For a discussion of these free riding incentives, see generally Keohane \& Victor, supra note 215 .

217 For more details, see Sustainable Development Goals, DIVSION FOR SustaINaBle Dev., UNITED NATIONS, https://perma.cc/8EQG-EQRS (last visited Feb. 25, 2017). For a discussion of the development and theory of SDGs, see generally Jeffrey D. Sachs, From Millennium Development Goals to Sustainable Development Goals, 379 LANCET 2206 (2012).

218 Rishikesh Bhandary et al., Taking Stock: $A$ Brief Analysis of the UN Sustainable Development Summit, INT'L INST. FOR SUSTAINABLE DEV. (2015), https://perma.cc/SF5X-KFHG; Peter Hazlewood \& Mathilde Bouyé, Sustainable Development Goals: Setting a New Course for People and Planet, WORLD RES. INST.: INSIGHTS (Sept. 18, 2015), https://perma.cc/GAJ2-TGKJ; Jeffery D. Sachs, Opinion, Sustainable Development: A New Kind of Globalization, Bos. GLOBE (July 19, 2016), https://perma.cc/DDW2-6RAK. 
approach that recognizes that presidents and prime ministers have little dayto-day control over the carbon footprints of their societies, and real solutions will have to come from mayors and governors as well as corporate executives and other community leaders. ${ }^{210}$

In a very diverse world with a wide range of national interests and priorities, and in a context where little gets agreed upon, the fact that the world community has come together on these common platforms for action should be seen as big news. Of course, both the SDGs and the Paris Agreement have gaps and fuzzy elements-the inevitable endpoint of any complex negotiation that requires compromise. But the broad consensus that emerged is a testament to the appreciation of world leaders for the profound degree of interdependence that exists not just across issues but among all countries sharing the planet Earth. ${ }^{220}$

One last vector of required integration in the governance context deserves special mention: the need for bipartisanship. As noted earlier, the structure of the American government makes it easy for a disgruntled minority to block political action. ${ }^{221}$ Thus, any prospect for transformative change requires Democrats and Republicans to work together. ${ }^{222}$ Even if a one-party majority can vote through a reform agenda, those reforms are unlikely to succeed if the opposition party feels aggrieved and actively seeks to undermine the new regime. ${ }^{223}$ For instance, when things go wrong, rather than working together to fix the problems, they will call oversight hearings (at the state if not federal level), issue press releases condemning the failures, and commission studies that highlight the shortcoming of the new framework. Big changes that truly break new ground will almost always entail some mistakes in the first pass at redefining the policy approach-and thus require refinement over time. ${ }^{224}$ Real success, sustained over time, therefore demands bipartisan collaboration.

219 See Daniel C. Esty, Regearing the Global Response to Climate Change: 5 Past Mistakes the 2015 Paris Agreement Needs to Fix, HuFFingTon Post (Dec. 9, 2015), https://perma.cc/56CZ$897 \mathrm{Y}$.

220 Perhaps the high water mark in this regard was set by Pope Francis with his Laudato Si' commentary. POPE Francis, LAUDATO SI': ON CARE FOR OUR COMMON HOME (2015). For a sampling of quotes from other world leaders, see generally Alister Doyle, 16 Quotes from World Leaders on the Paris Climate Agreement, WORLD ECON. F. (Dec. 12, 2015), https://perma.cc/M8M4-BJSC.

221 See supra Part I.

222 See BaRBara SinClaIR, UNORTHODOx LAWMAKING: NEW LEgISLATIVE PROCESSES IN THE U.S. CONGRESS 134-36 (5th ed. 2016) (describing how Congress has responded to increased polarization and political gridlock by using unorthodox legislative tools to pass statutes).

223 See, e.g., Toluse Olorunnipa, Obama Says Obamacare Has 'Real Problems' Congress Refuses to Fix, BLOOMBERG (Oct. 3, 2016), https://perma.cc/X683-5BF6 (discussing rising rates in government-run marketplaces); Editorial, Taming Affordable Care Act Premiums, N.Y. TIMEs, Oct. 26, 2016, at A30 (calling for Congress and the winner of the 2016 Presidential Election to fix existing problems with the Affordable Care Act).

224 Freeman \& Spence, supra note 6, at 3, 7 (2014) (arguing that, in the face of congressional dysfunction, agencies have assumed the mantle of updating old statutes to address new problems); Eric Biber, Adaptive Management and the Future of Environmental Law, 46 AKRON L. REV. 933, 934-36 (2013) (describing the benefits of an adaptive management approach to environmental policymaking that uses experimentation and learning by doing to develop 


\section{RESETTING THE 21ST CENTURY ENVIRONMENTAL POSSIBILTT FRONTIER}

Today's environmental challenges have evolved considerably from the issues of the 20th century that motivated the modern American structure of environmental law that came into being in the 1970s and $80 \mathrm{~s}$. Likewise, our capacity to respond has been transformed by advances in scientific, data analytics, technological, management, political science, economic, and public administration theory and practice. I identify in this Part a number of new realities that both redefine the core problem set on which environmental policy must focus and extend the toolkit available for response.

Some of these realities offer opportunities that could make it easier to achieve the goal of a recast environmental regime that is lighter and stronger, supported by Republicans as well as Democrats, and capable of spurring innovation and thus promoting continuous improvement in pollution control and natural resource management. Some of the other changes in context will make it harder to achieve progress. And a number of these elements of the policy context are interconnected and interact. Information technologies, for instance, offer new ways for governments to communicate with the public-changing the policy possibility frontiers for both environmental agencies and people. All of these new realities shape the prospects for addressing the political, structural, and operational issues that diminish the effectiveness of our current environmental regime and hold back efforts at reform-and thus need to be factored into the strategies for moving toward a more sustainable future that get advanced.

\section{A. Advances in Information and Communications Technologies}

The Digital Age has changed in fundamental ways how we live and communicate, how companies make and sell goods and services, and even how baseball teams pick players. ${ }^{225}$ Yet the impact of the breakthroughs in information and communications technologies (ICT) on our basic program of environmental protection has been rather modest. ${ }^{228}$ But the world of

regulatory approaches, while also acknowledging some challenges to this strategy); Charles $\mathbf{F}$. Sabel \& Jonathan Zeitlin, Experimentalist Governance, in THE OXFORD HANDBOOK OF GOVERNANCE 1, 2-4 (David Levi-Faur ed., 2012) (highlighting the potential value of "experimentalist governance," which "establishes deliberately provisional frameworks for action and elaborates and revises these in light of recursive review of efforts to implement them in various contexts.")

225 See generally Andrew McAfee \& Erik Brynjolfsson, Big Data: The Management Revolution, HARV. BUS. REV., Oct. 2012, at 59 (outlining implications of big data for business operations); Michael Lewis, MONEYBALl: THE ART OF WinNING AN UNFAIR GAME (2004) (discussing how rigorous statistical analysis can revolutionize the selection of a baseball team-and highlighting the breakthrough thinking of Theo Epstein, who later delivered World Series championships in both Boston and Chicago with his data-driven approach to player selection).

226 Michael B. Gerrard \& Michael Herz, Harnessing Information Technology to Improve the Environmental Impact Review Process, 12 N.Y.U. ENVTL. L.J. 18, 19 (2003) (noting agencies have 
abundant and low-cost data makes it much easier to move away from command-and-control regulation toward market mechanisms for addressing environmental harms-and enables a whole series of nonregulatory strategies for improved pollution control and natural resource management.

\section{Big Data}

Much of the design of the 20th century environmental law model can be traced to the scarcity and high cost of data of the $1960 \mathrm{~s}$ and $70 \mathrm{~s} .{ }^{27}$ The emphasis on government-mandated uniform pollution standards must be understood as a choice that was driven by the limited information available about the air and water pollution problems and chemical exposure concerns that became unavoidably vivid in that era. ${ }^{228}$ Had there been accurate and low-cost data that allowed emissions to be traced from source to impact, there might not have been a need to overlay a statutory approach to environmental problems on top of the common law. ${ }^{229}$ But tort law failed in the face of difficulties in mapping the flow of pollution harms, separating out the distinct emissions sources within polluted airshed or watershed, clarifying the impacts on people's wellbeing as well as on flora and fauna, establishing the causation between identified pollutants and observed epidemiological and ecological effects, and putting a value on these harms. ${ }^{230}$ This led to our current framework of environmental statutes, a defining

been slow to harness the potential of the digital revolution in implementing the requirements of the National Environmental Policy Act of 1969, 42 U.S.C. $\$ \$ 4321-4370 \mathrm{~h}(2012)$ ).

227 See Gregg P. Macey, The Architecture of Ignorance, 2013 UTAH L. REv. 1627, 1627-31 (2013).

228 See, e.g., RACHEL CARSON, SILENT SPRING 15-38 (40th anniversary ed. 2002) (depicting the harmful effects of chemical exposure to people and the environment, which were relatively unknown by the public at the time of publication); see also Riley E. Dunlap, Trends in Public Opinion Toward Environmental Issues: 1965-1990, 4 Soc'Y \& NAT. RESOURCES 285, 288 (1991) (noting that Gallup polls showed that the share of Americans who saw air and water pollution as a national problem tripled between 1965 and 1970.).

229 See Maloney \& Yandle, supra note 34 , at 246 (" $[\mathrm{W}]$ hen information costs are considered, one might argue that the development of clean air regulation since 1970 has actually been the best possible approach.").

230 See, e.g., Mark Latham, Victor E. Schwartz \& Christopher E. Appel, The Intersection of Tort and Environmental Law: Where the Twains Should Meet and Depart, 80 FordHAM L. REv. 737, 754 (2011) ("The challenges presented by many modern complex environmental tort actions have prompted Congress and state legislatures to enact statutes to limit or facilitate the remediation of certain harms to the environment. Their reasons for doing so have not only been to improve upon the common law actions and introduce greater precision in addressing complex litigation issues, but also to expand the scope of recovery to a wider range of potential harms. In addition, the legislative complement to the common law has enabled other policy objectives to be pursued, enhancing the overall effectiveness, efficiency, and availability of legal recourse for an environmental injury."); David A. Dana, The Mismatch Between Public Nuisance Law and Global Warming, 18 SUP. CT. ECON. REv. 9 (2010) (discussing the challenges of using tort law to address climate change); Douglas A. Kysar, What Climate Change Can Do About Tort Law, 41 ENVTL. L. 1 (2011) (same). 
feature of which is their provision of "bridges" over pervasive information gaps. ${ }^{231}$

The 21st century is not similarly constrained. Data on all the critical items catalogued above are now much more readily available, and computerpowered statistical tools make environmental analysis more sophisticated and easier to do. We now have the opportunity to create a Big Data model for a sustainable future, building on the ICT breakthroughs of what some have called the "Fourth Industrial Revolution."

If we had had in 1970 the information and tools we have now, we almost certainly would not have designed the environmental protection regime that we live with today. The reliance on uniform national standards was a way of short-circuiting information gaps and avoiding the cost of tailoring rules to specific circumstances in a data-limited world. ${ }^{233}$ The emphasis on best available technologies, which required the government to define the pollution control path forward, can also be traced to the same data limitations. ${ }^{234}$ Likewise, constrained abilities to gauge pollution levels made the best available technology approach, where inspectors needed only to determine if the required technology was in place, seem like the best approach possible.

Today's low-cost and abundant data world makes it much easier to deploy price signals and pollution charges. ${ }^{235}$ Advances in sensors and data communications mean that sources of emissions are much easier to track. ${ }^{236}$

231 John S. Applegate, Bridging the Data Gap: Balancing the Supply and Demand for Chemical Information, 86 TEx. L. REv. 1365, 1396 (2008) (discussing "[t]he information advantages of technology-based standards").

232 KLaus SchwaB, THe Fourth Industrial Revolution 6-8 (2017). Of course, while Big Data has had high-profile successes, it is still a "young science"-with some spectacular failures, such as the faulty 2016 Presidential Election data analytics that lead nearly all pollsters to miss Donald Trump's electoral rise. See, e.g., Steve Lohr \& Natasha Singer, How Data Failed Us in Calling an Election, N.Y. TIMES, Nov. 10, 2016, at B1; see also NovECK, supra note 113, at 101 (arguing that Big Data can lead to information overload and stressing that "human expertise ... [is needed] to curate and align data with decisionmaking.").

233 Wendy E. Wagner, The Triumph of Technology-Based Standards, 2000 U. ILL. L. REv. 83, 93-94 (2000) ("The theory behind [technology-based standards] is thus cost-blind and could be extremely inefficient. But, consistent with the resiliency of these standards, the information gaps are typically so large and asymmetrical (with the regulated entities enjoying far greater information) that whatever inefficiencies occur are expected to be less than the costs entailed in identifying and implementing a more 'efficient' control strategy. Avoiding the transaction costs associated with arguing over the extent or import of an externality that largely escapes quantification and scientific understanding is, therefore, administratively brilliant as well as morally compelling." (footnote omitted)).

234 Shapiro \& McGarity, supra note 69, at 746 (describing how Congress amended the Clean Air Act and Clean Water Act to specifically allow EPA to implement technology-based approaches when "Congress recognized that the overwhelming uncertainties and analytical quagmires concerning risk assessment were bogging down the toxic substance programs.").

235 Esty, Information Age, supra note 127, at 175-80 (discussing how new information technologies can mitigate information gaps and create better functioning and more robust pollution markets).

236 David L. Markell \& Robert L. Glicksman, Dynamic Governance in Theory and Application, Part I, 58 ARIz. L. REv. 563, 613-14 (2016) (noting that technological advancements in pollution monitoring could revolutionize environmental regulatory enforcement). 
Pollution levels can be more accurately established. ${ }^{237}$ And advances in emissions modeling and risk assessment make putting a price on pollution much easier to do.

The Clean Air Act Amendments of 1990's acid rain program ${ }^{238}$ demonstrated that the $\mathrm{SO}_{2}$ and $\mathrm{NO}_{x}$ emissions from power plant smokestacks could be accurately tracked, making a regime of tradable emissions allowances possible. ${ }^{239}$ In the intervening years, sensors and communications technologies have gotten even better so that market mechanisms are now feasible in almost all pollution contexts. ${ }^{240}$ This Information Age breakthrough therefore makes possible a wholesale shift toward "pricing" pollution - ending our reliance on government-established performance standards or best available technology. Not only could every smokestack be equipped with a pollution gauge, but even small pollution sources could be equipped with emissions monitoring devices. ${ }^{241}$ Nonpoint sources of water pollution could be similarly tracked with charges imposed for nitrogen and phosphorus loadings into rivers and streams. ${ }^{242}$

Note, however, that while the government would be able to get out of the time-intensive and expensive regulatory requirements of the old command-and-control regime, it would need to do the analysis required to put a price on various pollutants and establish the system for collecting the emissions charges. ${ }^{243}$ EPA would still have to establish safety thresholds above which pollution levels would not be allowed to go. And some substances, such as lead, with its well-established severe public health

237 Giles, supra note 88, at 24-25 (describing technological advancements that have made fine-grained, real-time monitoring of pollution levels possible for many sources).

238 Clean Air Act, 42 U.S.C. $\$ \S 7651-7651 o(2012)$.

239 Blas Pérez Henríquez, Information Technology: The Unsung Hero of Market-Based Environmental Policies, RESOURCES, Fall/Winter 2004, at 9, 9-10 (arguing that new information and communication technologies were critical to the success of the acid rain program); Joseph A. Kruger, Brian J. McLean \& Rayenne Chen, A Tale of Two Revolutions: Administration of the SO2 Trading Program, in EMISSIONS TRADING: ENVIRONMENTAL POLICY's NEW APPROACH 115, 116 (Richard F. Kosobud ed., 2000) ("In its role as the emissions and allowance 'accountant,' EPA must handle vast amounts of information. In addition to processing the information for compliance purposes, EPA must make emissions and allowance information accessible to facilitate an efficient allowance market and to build public credibility in the emissions trading approach. Without recent advances in information technologies, these activities would be considerably more difficult if not impossible.").

240 Esty, Information Age, supra note 127, at 157 ("We thus are approaching the day when virtually all emissions will be susceptible to tagging, tracking, and measurement at relatively low cost.").

241 Jason Plautz, New Technologies Let EPA 'Collect a Lot More Data In a Lot More Places', GREENWIRE (Apr. 1, 2014), https://perma.cc/CV67-XKVS (describing EPA's expectations for nearterm technological advancements in air pollution monitors, including small mobile devices that can enable EPA to "fine-tune its picture of the air Americans breathe").

242 See, e.g., New Soil Sensor Could Reduce Fertilizer Use, OR. BEST (Mar. 6, 2014), https://perma cc/XRD4-C85G (describing a new Oregon company that developed "a wireless soil sensor to detect nitrate levels in fields").

243 Lawrence H. Goulder, Markets for Pollution Allowances: What Are the (New) Lessons?, J. ECON. PERSP., Winter 2013, at 87, 89-90 (noting that difficulties monitoring pollution levels has limited the application of cap-and-trade programs in the past). 
effects, would still need to be banned altogether in most uses and applications. $^{244}$

Our current data-rich era not only permits a shift away from commandand-control mandates toward pollution charges, it also facilitates, as noted earlier, a more integrated approach to environmental protection. We are much better positioned to end pollution spillovers - at least those that have historically been permitted -at little or no cost. ${ }^{245}$ We are now able, as economists would say, to internalize externalities broadly. ${ }^{246}$ Advances in ICT capacity make it relatively easy to impose harm charges on all (beyond de minimis) pollution, which would largely eliminate the incentive to shift contaminants from one form to another.

Similarly, a comprehensive regime of harm charges-rather than government-mandated pollution controls-would create much more choice for producers and consumers-addressing a core concern of those who prize liberty and who fear that our current regulatory regime is too rigid and costly. ${ }^{247}$ Factory managers (not government regulators) would determine how far to push pollution controls-recognizing that a price would be paid for any residual emissions. As numerous academic studies have shown, the shift toward market-based pollution price signals offers greater flexibility, lower costs, and an ongoing incentive to reduce emissions. ${ }^{248}$

In other circumstances, information disclosure, rather than government mandates, could provide consumers with the facts and figures they need to choose their own level of environmental protection. ${ }^{248}$ One can imagine in the not-too-distant future a wider range of products with "environmental facts" on their labels or barcodes that can be read by smartphones, putting

244 See, e.g., Herbert Needleman, Lead Poisoning, 55 ANN. REV. MED. 209 (2004) (reviewing three decades of scientific research on the health effects of lead).

245 Giles, supra note 88, at 24 (arguing that advanced monitoring technologies can help overcome the challenges of regulating smaller sources of pollution).

246 Goulder, supra note 243 , at 98.

247 Ackerman \& Stewart, supra note 125, at 1341-46 (observing that one of the major benefits of market mechanisms is their flexibility).

248 See, e.g., id. at 1341-46; Stewart, Regulation, Innovation, and Administrative Law, supra note 73, at 1327-29; see also Daniel C. Esty, Breaking the Environmental Law Logjam: The International Dimension, 17 N.Y.U. ENVTL. L.J. 836, 838-50 (2008) (discussing evidence that suggests a global "clean tech" marketplace would maximize environmental innovation and efficiency); Goulder, supra note 243, at 89-90 (highlighting two factors that led to the success of market-based strategies-strong monitoring capabilities and compliance incentives); Hahn \& Stavins, supra note 129, at 14-15 (advocating for both market- and regulation-based processes, depending on the specific issues to be addressed); Robert N. Stavins, What Can We Learn from the Grand Policy Experiment? Lessons from $\mathrm{SO}_{2}$ Allowance Trading, J. ECON. PERsP., Summer 1998 , at $69,70-71,79-80$ (describing how the successful $\mathrm{SO}_{2}$ allowance trading program offers lessons about the private sector's ability to make tradeable permit systems work); Richard Schmalensee \& Robert N. Stavins, Lessons Learned from Three Decades of Experience with Cap-and-Trade 16-19 (Nat'l Bureau of Econ. Research, Working Paper No. 21742, Nov. 2015) (explaining how cap-and-trade has long been proven to be environmentally and cost effective relative to less flexible command-and-control approaches).

249 Konar \& Cohen, supra note 139, at 109 (noting a growing interest among academics and policymakers in using mandatory disclosure requirements to affect firm behavior and consumer choice in the environmental arena). 
the buyer in a position to make an informed environmental choice based on family preferences and circumstances. ${ }^{250}$ Of course, government-defined safety thresholds would still be needed. ${ }^{251}$ Expanded choice and the opportunity for individuals to balance risk, cost, and other factors according to their own preferences above the threshold will be much easier in our data-rich future. Such a reassignment of decision making would be particularly appropriate where individuals are both capable of and interested in making their own decisions-and where neither spillovers nor equity issues are overwhelming. ${ }^{252}$

The growing interest in "organic" food, which almost always entails some price premium, ${ }^{253}$ demonstrates the potential for such individualization of environmental protection. Indeed, information disclosure may make particular sense in the food context where people are willing and able to invest in making informed product selections. ${ }^{254}$ But information strategies might not work with regard to the choice of electricity providers, where the public is not well positioned to make informed choices. ${ }^{265}$

In addition to setting safety thresholds, the government might well need to establish the core set of metrics to be reported and the methodologies underlying these metrics-as well as monitoring and verifying the accuracy

250 For example, companies can now meet genetically modified organism (GMO) labeling requirements by attaching an identifying barcode, which, if scanned by a smartphone, would provide consumers with information on the product. Heather Haddon, Consumer Advocates Wary of Digitally Coded Food Labels, WALL STREET J. (Aug. 3, 2016), https://perma.cc/CF58S63C; see also Daniel C. Esty \& Marian R. Chertow, A Vision for the Future, in THINKING Ecologically: THe NeXT Generation of Environmental Policy 231, 238 (Marian R. Chertow \& Daniel C. Esty eds., 1997) (anticipating such eco-labels).

251 Of course, any label would have to be carefully designed to avoid unintended negative consequences in consumer behavior. See Jay S. Golden et al., Sustainable Product Indexing: Navigating the Challenge of Eco Labeling, 15 ECOLOGY \& Soc'Y, no. 3, 2010, art. 8 at 2 (cautioning against labeling schemes that single out a particular risk and ignore the interactions between different risks in an interconnected system).

252 See Marc D. Shapiro, Equity and Information: Information Regulation, Environmental Justice, and Risks from Toxic Chemicals, 24 J. POL'Y ANALYSIS \& MGMT. 373, 373-74 (2005) (finding that the Toxics Release Inventory, an information disclosure instrument, caused manufacturers to reduce emissions, but that emission reductions tend to be larger in more advantaged communities); see also Mark Stephan, Environmental Information Disclosure Programs: They Work, but Why?, 83 SocLAL SCI. Q. 190, 192 (2002) (observing that the core rationale of information disclosure programs is to make "information acquisition less costly").

253 Edward C. Jaenicke \& Andrea C. Carlson, Estimating and Investigating Organic Premiums for Retail-Level Food Products, 31 AgRIBUSINESS 453, 453 (2015).

254 There are, of course, also important limitations to information regulations in the food arena. For instance, research has found that calorie labeling and other information disclosure efforts have had little impact on obesity. See Kamila M. Kiszko et al., The Influence of Calorie Labeling on Food Orders and Consumption: A Review of the Literature, 39 J. COMMUNTTY HEALTH 1248, 1265 (2014). Instead, researchers are increasingly turning to behavioral economics for solutions to this health problem, proposing that "nudges" and healthy default rules could be used to help overcome the self-control problems associated with obesity. See Julie S. Downs et al., Strategies for Promoting Healthier Food Choices, 99 AM. ECON. REv. (PAPERS \& PROC.) 159, 160, 163 (2009).

255 Bernhard Truffer, Jochen Markard \& Rolf Wüstenhagen, Eco-labeling of ElectricityStrategies and Tradeoffs in the Definition of Environmental Standards, 29 ENERGY POL'Y 885 (2001) (discussing a number of challenges to the "eco-labeling" of electricity). 
of the information reported. In doing so, the government would make the "market" for environmental choice work better-just as government verification of SEC filings provides a level of confidence to investors making decisions about which stocks to buy. ${ }^{257}$

The full promise of Big Data has just begun to emerge in the environmental arena. ${ }^{258}$ As ecologists, epidemiologists, economists, and risk analysts bring advanced data analytics fully to bear in their research, the zone of uncertainty around pollution problems and resource consumption will shrink. ${ }^{258}$ Computer modeling will facilitate more rapid and accurate exploration of policy options. ${ }^{260}$ Such tools will also facilitate more comprehensive analysis when multiple vectors of exposure and other risk factors must be combined. ${ }^{261}$ For example, in determining the safe level of pesticide residue on food, there will be a much greater capacity to establish total chemical exposure and understand interactions as the basis for regulatory standards. ${ }^{262}$

Statistical advances will also allow modeling assumptions to be tested and explored-and made clear to policymakers. Advancements in computing power, for example, have led to the creation of "integrated assessment models," or climate-economy simulation models that allow

256 Konar \& Cohen, supra note 139 , at 110 (noting that mandatory disclosure requirements can be viewed as a form of market-based incentives for firms).

257 What We Do, SEC. \& EXCHANGE COMMISSION, https://perma.cc/X22F-R3AM (last visited Feb. 25, 2017) (noting that SEC was "designed to restore investor confidence in our capital markets by providing investors and the markets with more reliable information and clear rules of honest dealing").

258 For a survey of current efforts to incorporate Big Data into environmental regulation, see generally Linda K. Breggin \& Judith Amsalem, Big Data and the Environment: A Survey of Initiatives and Observations Moving Forward, 44 Envtl. L. Rep. (Envtl. L. Inst.) 10,984 (Nov. 2014). But see Rónan Kennedy, Rethinking Reflexive Law for the Information Age: Hybrid and Flexible Regulation by Disclosure, 7 GEO. WASH. J. ENERGY \& ENVTL. L. 124, 125 (2016) (arguing that "no coherent perspectives, approaches, or frameworks have developed" for integrating advancements in information technologies into environmental regulation); Esty, Measurement Matters, supra note 140 (describing the opportunities for new information technologies to improve environmental decision making).

259 Esty, Information Age, supra note 127, at 165 (noting that new information technologies will enable environmental decision making to increasingly "rely on actual on-the-ground results rather than expert opinion or, worse yet, rhetoric and emotion").

260 Kennedy, supra note 258, at 126 ("Computer modelling allows for better forecasting. With improved processing speeds, and genetic algorithms, models can be tested and adapted in very little time. This expands the scope and span of control available to policymakers. It could also improve the policymaking process by grounding policy programs in real results, identifying failing programs and the best solutions.").

261 Omer Tene \& Jules Polonetsky, Big Data for All: Privacy and User Control in the Age of Analytics, 11 Nw. J. TECH. \& INTELL. PROP. 239, 248 (2013) (observing that “[b]ig data use within the 'smart grid' context" is enabling grid operators to more "precisely locate power outages or other problems, including cyber-attacks or natural disasters," as well as providing consumers with "more choices on means, timing, and quantity of electricity they use").

262 R. Luxton \& J. Hart, The Rapid Detection of Pesticide Residues, in PESTICIDE, VETERINARY AND OTHER RESIDUES IN FOOD 294, 311 (David H. Watson ed., 2004) (noting that "the field of biosensors is moving forward at a terrific pace" and describing "a range of new technologies being developed at the moment to enhance the performance of rapid detection and measurement of pesticides"). 
researchers to quickly test a variety of climate policy paths. ${ }^{263}$ The use of sensitivity analysis and other tools will mean that decision makers can refine their models - and establish with greater clarity the drivers of good (or bad) outcomes. ${ }^{264}$ Likewise, policy interventions will be able to be tracked with greater precision-facilitating the identification of successful policy approaches and the dissemination of best practices. ${ }^{265}$ In a similar vein, enhanced capacity for data collection, normalization, and display will make benchmarking and comparative analysis easier and more relevant. ${ }^{266}$ Leaders will be highlighted and laggards spurred on to better performance. ${ }^{267}$

All of these advances will make the pricing of harms more accurate and capable of further refinement. In particular, emissions pricing might well vary by time and circumstance-just as the tolls Singapore charges for cars in its central business district vary with the time of day and traffic congestion. ${ }^{268}$ Differential pricing based on divergent impacts would also be

263 William D. Nordhaus, Professor of Econ., Yale Univ., Keynote Address at the 19th Annual Conference of the European Association of Environmental and Resource Economists: Integrated Economic and Climate Modeling 4 (June 29, 2012) (slides available at https://perma.cc/TX84-LP66).

264 Sophisticated energy systems models, for example, were recently used to evaluate the effects and refine the parameters of the Clean Power Plan. See, e.g., DANIEL A. LASHOF ET AL.,

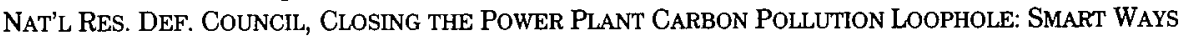
the Clean Air act Can Clean Up America's Biggest Climate Polluters (2013), https://perma.cc/NL'J2-Q3T7.

265 Esty, Measurement Matters, supra note 140 (discussing how comparative analysis can enhance environmental policy outcomes). The Obama Administration has been particularly attentive to evidence-based policymaking. See Ron Haskins \& Jon Baron, The Obama Administration's Evidence-Based Social Policy Initiatives: An Overview, in NESTA, EvidencE FOR SOCIAL POLICY AND PRACTICE: Perspectives ON How RESEARCH AND Evidence CaN Influence Decision MAKING IN PUBLIC SERVICES 28, 28 (2011) ("The Obama administration has created the most expansive opportunity for rigorous evidence to influence social policy in the history of the US government. No president or budget director for a president have ever been so intent on using evidence to shape decisions about the funding of social programs as President Obama and former Budget Director Orszag.").

266 The Environmental Performance Index, for example, creates standardized environmental metrics that allow for comparison of performance across countries and the identification of leaders and laggards. See ANGEL HSU ET AL., YALE CTR. FOR ENVTL. LAW \& POLICY ET AL., 2016 EnVIRonmental Performance Index Report: Global METRICS FOR THE ENVIRONMENT 27-28 (2016), https://perma.cc/BZL8-EM23. For a history of the development of the Environmental Performance Index, see Daniel C. Esty \& John W. Emerson, From Crises and Gurus to Science and Metrics: Yale's Environmental Performance Index and the Rise of Data-Driven Policymaking, in ROUTLEDGE HANDBOOK ON SUSTAINABILITY INDICATORS, supra note 140.

267 ESTY \& RUSHING, supra note 140, at 34-35; see also Stephan, supra note 252, at 193-94 (discussing how information disclosure regulations can "shock and shame" actors into performing better); Kennedy, supra note 258, at 133 ("The social impact of being explicitly highlighted for bad performance in a 'name and shame' campaign may serve as a form of punishment.").

268 For details on the Singapore program, see ED PIKE, INT'L COUNCIL ON CLEAN TRANSP., CONGESTION CHARgING: CHALLENGES AND OPPORTUNITIES 7-8 (2010), https://perma.cc/DNH4N5VH. Differential pricing is now standard in many other settings: Uber's ride share pricing, Priceline's hotel room charges, and airline ticket costs. 
possible. ${ }^{269}$ This capacity could translate into higher charges if pollution is affecting people or places that would be seen as deserving special caresuch as air emissions blowing into a national park or over a hospital. ${ }^{270}$ Likewise, it may well become possible in the next few decades to identify individuals who are being affected by environmental harms, ${ }^{271}$ and therefore move to a system whereby the charges collected are paid out to these "victims" rather than being retained by the government. ${ }^{272}$ The first stages of such a process can be seen in 2016 in the offer by the developers of the Swanton wind farm in Vermont to compensate neighbors affected by the nearby turbines. ${ }^{273}$

\section{Internet and Communications Breakthroughs}

Real-time data links and online communications offer another set of capabilities that will enable a transformed 21st century approach to sustainability. ${ }^{274}$ As noted above, emissions can be tracked and pollution

269 See, e.g., Joskow \& Wolfram, supra note 206, at 382 (noting that advances in communications and metering technologies now allow for the dynamic pricing of electricity that captures time variations in the marginal cost of energy).

270 Emily G. Snyder et al., The Changing Paradigm of Air Pollution Monitoring, 47 ENVTL. SCI. \& TECH. 11369, 11369 (2013) ("[The air pollution monitoring] paradigm is changing with the materialization of lower-cost, easy-to-use, portable air pollution monitors (sensors) that provide high-time resolution data in near real-time.").

271 COMm. ON HUMAN \& ENvTL. EXPOSURE SCI. IN THE 21st CENTURY, NAT'L RESEARCH COUNCIL OF THE NAT'L ACADS., EXPOSURE SCIENCE IN THE 21ST CENTURY: A VISION AND STRATEGy 9 (2012) ("Developing ubiquitous monitoring for personal exposure assessment will depend on rapid advances in sensor technologies. Despite recent advances, personal sensors still have only modest capacity to obtain highly selective, multistressor measurements. There is a need for a wearable sensor that is capable of monitoring multiple analyses in real time. Such a device would allow more rapid identification of 'highly exposed' people to help to identify sources and means of reducing exposures. Recent advances in nanoscience and in nanotechnology offer an unprecedented opportunity to develop very small, integrated sensors that can overcome current limitations.").

272 Of course, while technology may eventually enable the identification of victims of present environmental harms, it cannot resolve the moral and political determinations that must be made with respect to the assignment of responsibility. In the case of climate change, for example, assigning blame for global warming induced damages can be quite ethically and politically tricky. See generally Daniel A. Farber, Responsibility for Historic Carbon Emissions: Lessons from Tort and Statutory Compensation Schemes (U.C. Berkeley Sch. of Law, Pub. Law Research Paper No. 2404372, Mar. 4, 2014), https:/perma.cc/9R5G-VKZ7 (discussing some of these complex ethical judgments relating to climate responsibility).

273 Joel Banner Baird, Swanton Wind Power Plan Filed with Regulators, Burlington FreE PRESS (Sept. 9. 2016), https://perma.cc/3YYG-Y39P (noting that Swanton's submission to Vermont regulators included an offer to buyout protesting neighbors); Tom Benton, Swanton Wind Files Application; Company Offers to Buy Homes Nearest Turbines, ST. ALBans MESSENGER (Vt.), Sept. 9, 2016; at A1 (observing that the wind developers are confident that they will be able to resell the approximately twenty homes falling within the buyout range).

274 See, e.g., Howard B. Glasgow et al., Real-time Remote Monitoring of Water Quality: $A$ Review of Current Applications, and Advancements in Sensor, Telemetry, and Computing Technologies, 300 J. EXPERIMENTAL MARINE BIOLOGY \& ECOLOGY 409, 409 (2004) ("Recent advances in communication and sensor technology have catalyzed progress in remote monitoring capabilities for water quality."). 
charges collected at very low cost in our Information Age--making a pricebased pollution control system much more feasible than in the past. ${ }^{275}$ Moreover, as highlighted above, any sustainability-minded buyer with a smartphone and access to critical "environmental facts" will be positioned to make better informed purchases. ${ }^{276}$ In aggregate, such "green consumers" put market pressure on companies to produce more sustainable products. ${ }^{277}$ Ultimately, such consumer preferences can transform whole industries. ${ }^{278}$ For example, "dolphin-safe" labels on tuna helped eliminate fishing practices that had led to thousands of dolphin deaths as tuna buyers refused to purchase cans without the dolphin-safe promise. ${ }^{279}$ Social media tools further enable the aggregation of individual views into a global force for change. ${ }^{280}$

Likewise, every person with a smartphone is a potential watchdog on environmental misbehavior-positioned to capture with a picture or video pollution threats. ${ }^{281}$ Companies (as well as governments and individuals) have come to recognize that such videos may go viral-creating a whole new structure of discipline against those whose pollution or resource consumption violates community standards. ${ }^{282}$

The internet and various e-government tools also promise to empower individual participation in governmental decisions at all levels like never

275 See supra notes 233-235 and accompanying text.

276 See supra notes 251-253 and accompanying text.

277 See, e.g., Konar \& Cohen, supra note 139, at 112 n.6 (noting that a small number of individuals can generate a significant amount of media attention and bad publicity for a firm"); Thomas P. Lyon \& Jay P. Shimshack, Environmental Disclosure: Evidence from Newsweek's Green Companies Rankings, 54 Bus. \& Soc'y 632, 633-34 (2015) (finding that Newsweek's ranking of the 500 largest U:S. firms in terms of sustainability impacted shareholder value); Sarah Very, The Rise of Eco-Friendly Consumer Products Puts Pressure on P\&G, BLoomBERG (Oct. 4, 2016), https://perma.cc/5P3X-G29X (describing how the rise of eco-friendly products is pressuring Procter \& Gamble to change its business strategy).

278 See Sheila Bonini \& Jeremy Oppenheim, Cultivating the Green Consumer, STAN. Soc. INNOVATION REV., Fall 2008, at 56, 56 (noting broad support among consumers for eco-friendly products).

279 For a review of the history and effects of dolphin-safe tuna labels, see Jani Actman, Dolphin-Safe Tuna Rules Just Got Tougher, NAT'L GeOgraPHC (March 25, 2016), https://perma.ce/YG6B-YWBT.

280 Thomas P. Lyon \& A. Wren Montgomery, Tweetjacked: The Impact of Social Media on Corporate Greenwash, 118 J. BUS. ETHICS 747, 747 (2013) (arguing that social media is "redefining interactions between corporations and civil society" that will enable activists to more effectively identify and challenge "corporate greenwashing"); Shelley H. Metzenbaum \& Gaurav Vasisht, What Makes a Regulator Excellent? Mission, Funding, Information, and Judgment, in ACHIEVING REGULATORY EXCELLENCE, supra note 53, at 148, 151 (arguing that new information sources, such as crowdsourcing, will help improve policy decision making and outcomes).

281 Angel Hsu et al., Development: Mobilize Citizens to Track Sustainability, 508 NATURE 33, 34-35 (noting that citizens are increasingly use smart phones, apps, and social media platforms to monitor and disseminate information on environmental quality).

282 P.N. Grabosky, Green Markets: Environmental Regulation by the Private Sector, 16 LAW \& POL'Y 419, 427-28 (1994) (discussing examples where consumer preferences for sustainability changed firm behavior). 
before. ${ }^{283}$ Once published online, proposed regulations (or standards or future pollution prices) are now open to review, comment, and critique by anyone with a computer or smartphone. Easy and low-cost access means many more people can participate in the policymaking processdemocratizing governmental decision making and potentially improving decisions as the "wisdom of the crowd" can be more easily brought to bear. $^{284}$

Of course, privileged access to decision makers by special intereststhrough lobbyists, public relations investments, think-tank funding, and campaign contributions-will need to be monitored and controlled, perhaps with disclosure rules and transparency tools that flag attempts to torque the outcome of decision processes. ${ }^{285}$ In this regard, Big Data tools promise to make it easier to trace spending on these items, and thus to map more fully the strands of influence on political and regulatory outcomes. ${ }^{286}$

The ease and speed of email also means that public participation processes can be reframed along much tighter timelines. In the snail mail era, sixty- or ninety-day comment periods might have been necessary. ${ }^{287}$ Today, thirty days should be sufficient for many review processes, with extended timetables only for the most complicated matters. Some NGOs

283 See, e.g., Barbara H. Brandon \& Robert D. Carlitz, Online Rulemaking and Other Tools for Strengthening Our Civil Infrastructure, 54 ADMIN. L. REv. 1421, 1433-35 (2002) (noting the widespread use of electronic dockets by various federal agencies and departments); Stephen M. Johnson, The Internet Changes Everything: Revolutionizing Public Participation and Access to Government Information through the Internet, 50 ADMIN. L. REv. 277, 279 (1998) (arguing that the internet has great potential to increase citizen access to the administrative state). Importantly, not all scholars agree that democratizing rulemaking is a good objective. Compare Stuart Minor Benjamin, Evaluating E-Rulemaking: Public Participation and Political Institutions, 55 DuKE L.J. 893, 939-41 (2006) (finding that the costs of e-rulemaking may outweigh the benefits), with Beth Simone Noveck \& David R. Johnson, A Complex(ity) Strategy for Breaking the Logjam, 17 N.Y.U. ENVTL. L.J. 170 (2008) (exploring how EPA might use new web-based tools to enhance expert citizen participation in environmental decision making).

284 There is, of course, a robust debate over whether e-rulemaking has, in fact, accomplished these goals. For a review of this literature, see generally Ann Marie Johnson \& Alexandru Roman, Reflections on E-Rulemaking: Challenges, Limitations and Unrealistic Expectations, 13 ELECTRONIC J. E-Gov'T 43 (2015). The empirical reality, however, does not change the normative value of the ideal.

285 For an in-depth discussion of agency capture, see generally PREVENTING REGULATORY CAPTURE: SPECIAL INTEREST INFLUENCE AND How TO LIMIT IT (Daniel Carpenter \& David A. Moss eds., 2014).

286 See Jerry L. MASHaw, Greed, Chaos, AND Governance: Using Public Choice to Improve PUBLIC POLICY 10-29 (1997) (providing an in-depth discussion of the various public choice failures that permeate governmental decision making); Adam Candeub, Transparency in the Administrative State, 51 Hous. L. REv. 385, 412-13 (2013) (arguing that Big Data can improve the transparency of government decision making); William N. Eskridge, Jr, Politics Without Romance: Implications of Public Choice Theory for Statutory Interpretation, 74 VA. L. REv. 275, 285-90 (1988) (discussing the formation of special interest groups and their influence over the supply of public goods); Esty, Optimal Governance, supra note 204, at 1515-18 (discussing public choice failures in the environmental policy context).

287 For an overview of rulemaking timetables, see generally VANESSA K. BURROwS \& TODD GARVEY, CONG. RESEARCH SERV., R41546, A BRIEF OVERVIEW OF RULEMAKING AND JUDICIAL REVIEW (2011). 
may complain about such compressed review schedule. But, as noted earlier, speed needs to be understood as an important virtue in 21st century environmental protection as we seek to lighten regulatory burdens without lowering standards. ${ }^{288}$

Perhaps the most exciting opportunities for environmental gain involve an almost opposite trend-shifting environmental decision making from overt individual action to smart systems (including a smart electric grid, ${ }^{289}$ smart appliances, ${ }^{200}$ and other technologies deploying artificial intelligence and the "internet of things" ${ }^{291}$ ) that optimize environmental outcomes based on decision rules set out in advance. So rather than having to turn up the heat when you arrive at home at the end of the day, the smart thermostat will have already reset the temperature, triggered by a signal from your smartphone that you are on the way home. ${ }^{292}$ And on days of peak energy demand, smart appliances will shut down for a few seconds per minute to reduce the strain on the grid. ${ }^{293}$ Such "demand response" strategies and "peak-shaving" reduce the need for expanded generation capacity with all of the cost that entails. ${ }^{294}$

\section{Transparency}

The dramatically more transparent world of the 21st century offers potential for a transformed approach to environmental protection. Access to critical data online provides a way for many more people to track pollution

288 See supra notes 106-113 and accompanying text.

289 See generally Joel B. Eisen, Smart Regulation and Federalism for the Smart Grid, 37 HARV. ENVTL. L. REV. 1 (2013) (exploring the benefits and barriers of the "Smart Grid").

290 See Stephanie M. Stern, Smart-Grid: Technology and the Psychology of Environmental Behavior Change, 86 CHI.KENT L. REV. 139, 146 (2011) (discussing the current state of smart appliance technologies).

291 See generally Nomusa Dlodlo, Adopting the Internet of Things in Environmental Management in South Africa, 32 INT'L Proc. CHEMICAL, BIological \& ENV'TL. ENGINEERING 45 (2012) (discussing possible applications of the "Internet of Things" technologies in environmental management); Andrew Guthrie Ferguson, The Internet of Things and the Fourth Amendment of Effects, 104 CALIF. L. REv. 805 (2016) (discussing the history and state of the "Internet of Things").

292 Katherine Tweed, Smart Thermostat Market Will Grow Tenfold by 2020, GREENTECH MEDIA (Nov. 1, 2013), https://perma.cc/MTS8-VVJV (reviewing projections from Navigant Research that show the global market for smart thermostats will grow from $\$ 100$ million today to $\$ 1.4$ billion in 2020 ).

293 See Cheryl Dancey Balough, Privacy Implications of Smart Meters, 86 CH.-KENT L. REv. 161,162 (2011) (noting the potential of smart appliances and other smart technologies to reduce electricity consumption).

294 Jeff St. John, Making the Case for Smart Grid to Shave Peak Power, GreEnTECH MEdiA (Aug. 2, 2012), https://perma.cc/GR8Q-6M5F (discussing a variety of smart grid technologies have been shown to reduce electricity consumption during periods of peak demand). Notably, these delegations of decision making authority to smart systems do not constitute losses in consumer choice. Many of these decisions, especially those in the energy consumption context, are not made deliberately or rationally by individuals. Indeed, in many cases, smart systems will simply be transforming an inefficient default (e.g., keep the lights on all the time) to a series of efficient decisions that track real-time changes (e.g., keep the lights on except for peak demand periods). 
control results or natural resource management performance, not just in the government context but also with regard to private sector performance. The demand for online corporate sustainability information is coming not only at the product level as discussed above, but also at the company level. ${ }^{295} \mathrm{~A}$ growing number of businesses want visibility on the sustainability track records of their suppliers. ${ }^{296}$ Indeed, Walmart's move towards requiring its more than 100,000 suppliers to report on a defined set of sustainability metrics, covering everything from greenhouse gases to food waste, has raised the environmental "game" of many companies, including tens of thousands in China. ${ }^{297}$

Further pressure for improved corporate sustainability reporting and greater transparency has begun to emerge from a growing set of sustainability-minded investors. ${ }^{298}$ According to the Global Sustainable Investment Alliance, as of 2014 , about $\$ 7$ trillion of U.S. assets under management are now invested in sustainable or socially responsible strategies, a $76 \%$ increase from $2012 .{ }^{299}$ Over the same period of time, global assets managed through a socially responsible lens rose from $\$ 13$ trillion to $\$ 21$ trillion-and now represent almost a third of all managed assets. ${ }^{300}$ The mainstreaming of sustainable investing ${ }^{301}$ has received a boost from a number of prominent thought leaders in the financial world, including Michael Bloomberg, Larry Fink, and James Gorman. ${ }^{302}$ As the framework of

295 See generally Stephan Vacho, Green Supply Chain Practices and the Selection of Environmental Techinologies, 45 INT'L J. PRODUCTION RES. 4357, 4358 (2007) (evaluating “the impact of environment-related activities in the supply chain on the adoption and implementation of environmental technologies in a plant").

296 Magali Delmas \& Ivan Montiel, Greening the Supply Chain: When is Customer Pressure Effective?, 18 J. ECON. \& MGMT. STRATEGY 171, 172 (2009) (observing that "[f]irms seeking to improve their environmental performance are increasingly concerned about the performance of other firms upstream in their supply chain").

297 Daniel C. Esty \& P.J. Simmons, The Green to Gold Business Playbook: How to IMPLEMENT SUSTAINABILITY PRACTICES FOR BOTTOM-LINE RESUlTS IN EVERY BUSINESS FUNCTION 32 (2011); Press Release, Wal-Mart Stores, Inc., Walmart Announces New Commitments to Drive Sustainability Deeper Into the Company's Global Supply Chain (Oct. 25, 2012), https://perma.cc/6AYB-BTHV (pledging Walmart, by 2017, to "buy 70 percent of the goods it sells in U.S. stores and in U.S. Sam's Clubs only from suppliers in the United States, China, and around the world who use the [Sustainability] Index to evaluate and share the sustainability of their products"). For background on the initiative, see Alisha Staggs, An Up-Close Assessment of Walmart's Sustainability Index, GREENBIz (May 17, 2013), https://perma.cc/V6CV-ZBU7; Marc Gunther, Game On: Why Walmart is Ranking Suppliers on Sustainability, GreENBIZ (Apr. 15, 2013), https://perma.cc/F4LZ-YDJX.

298 Daniel C. Esty \& Todd Cort, Corporate Sustainability Metrics: What Investors Need and Don't Get 6 (May 2016) (unpublished manuscript), https://perma.cc/H88G-854V (observing a "growing demand for corporate sustainability information among mainstream investors").

299 Glob. Sustainable INv. All., 2014 Global Sustainable Investment Review 4 (2015), https:/perma.cc/25GA-66TX.

$300 \quad$ Id. at 7.

301 Esty \& Cort, supra note 298, at 1.

302 Oliver Ralph, Companies Urged to Reveal Climate Change Impact; Investor Concerns, Fin. Times, Feb. 10, 2016, at 4; Matt Turner, Here Is the Letter the World's Largest Investor, BlackRock CEO Larry Fink, Just Sent to CEOS Everywhere, BUS. INSIDER (Feb. 2, 2016), 
environment-social-governance (ESG) metrics improves, an ever greater number of investors appears poised to bring sustainability factors to bear in their investment decisions-providing a powerful new (nonregulatory) logic for environmental care in the corporate world. ${ }^{303}$

Governments are also being pressured into greater transparency with regard to their sustainability performance. Benchmarking of environmental results has become much more common in recent years. The Environmental Performance Index (EPI) produced by researchers at Yale and Columbia, for example, offers a scorecard that ranks 180 countries on two dozen indicators of environmental public health and ecosystem vitality. ${ }^{304}$ Each biennial release of the EPI produces thousands of media articles as nations vie to move up the rankings and commentary flows over who is doing well (and less well) and why. ${ }^{305}$ As with the corporate sustainability rankings, the pressure for improved performance derives from the visibility of the results and the natural desire of those being ranked to lead rather than lag-not from any regulatory requirement or mandatory standard. ${ }^{306}$

Expanded tracking and publication of sustainability metrics and scorecards at the global, national, state or provincial, city, corporate, household, and even individual scales will further blossom in the years ahead. ${ }^{307}$ Such rankings spur competition for better performance and provide a mechanism for spotlighting best practices. ${ }^{308}$ Careful analysis of the data and comparative performance metrics can also be used to highlight anomalous results that might be an indication of policy failure, specialinterest manipulation, or corruption. ${ }^{309}$

https://perma.cc/TG2X-75H6; Press Release, Morgan Stanley, Morgan Stanley Establishes Institute for Sustainable Investing (Nov. 1, 2013), https://perma.cc/JAT5-H8GC.

303 Gregory Unruh et al., Mass. Inst. Tech. Sloan Mgmt. ReView, Investing for a

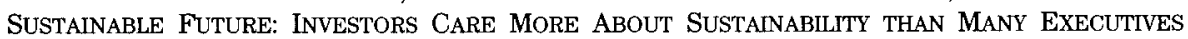
BELIEVE 3 (2016) (describing the emergence of new metrics and tools that "connect ESG performance with corporate performance").

304 HSU ET AL., supra note 281, at 18-19.

305 See, e.g., Julian Spector, Half the World Still Breathes Polluted Air, ATLANTIC: CITYLAB (Jan. 25, 2016), https://perma.cc/Y9EG-DN6K; Deoric, Australia Placed 13th in Yale's 2016 Environmental Performance Index, Aussie NeTwork NEwS (Jan. 28, 2016), https://perma.cc/5WV9-U8XP; Don Mosteller, "Yale's Lies?" EPIs Rankings Ignite National Controversy in Turkey, SAGE (Mar. 9, 2016), https://perma.cc/J2P8-DG77.

306 For a discussion of the multiple functions of performance metrics, including their role in legitimizing or delegitimizing government policies, see generally ALEX DE SHERBININ ET AL., EARTH INST. \& YALE CTR. FOR ENVTL. LAW \& POLICY, INDICATORS IN PRACTICE: HOW ENVIRONMENTAL INDICATORS ARE BEING USED IN POLICY AND MANAGEMENT CONTEXTS (2013).

307 For example, a number of countries -including Malaysia, China, and Tunisia-have taken steps towards creating their own national versions of the EPI. Id. at 5 .

308 Id. at 14 ("The ESI and EPI have successfully employed rankings to set up a competitive dynamic among countries. Experience has shown that high level policy makers pay attention to their ranking relative to neighbors or countries at similar development levels. They often respond by first questioning the data and methodology, and then, after further discussions, engaging in an analysis of performance on sub-components. The desire to improve one's image, if not always the on-the-ground reality, is a powerful motivator.").

309 See generally ESTY \& RUSHING, supra note 140, at 4 (outlining a framework for "thinking about data-driven decisionmaking as a new approach governing."); Isabel Gallego-Álvarez et al., Environmental Performance in Countries Worldwide: Determinant Factors and Multivariate 
In raising these questions, a framework of sustainability data and transparency can dramatically improve accountability by decision makers at every scale. ${ }^{310}$ Media, opposition political leaders, and NGO critics can use such metrics and comparative analyses to push Environment Ministers, Governors or Premiers, and Mayors to improve the results in their jurisdictions. ${ }^{311}$

Just as relevant metrics and benchmarking can motivate businesses and governments to strengthen their sustainability performance, comparative analysis can sharpen thinking at the household and individual levels. There is growing evidence that individuals are often more willing to undertake a home energy efficiency audit or to put up a solar array when they see others in their neighborhood do these things. ${ }^{312}$ Peer pressure and this "neighbor" effect are thus powerful tools for moving the world toward a sustainable future-and the mechanisms for bringing such comparisons into focus are multiplying. ${ }^{313}$ For instance, Opower's comparative energy use scorecard has helped 6.2 million people to identify efficiency opportunities. ${ }^{314}$ According to rigorous studies of the program, households that received reports on their energy use relative to that of a hundred similar neighbors reduced their consumption. ${ }^{315}$ Importantly, these energy saving effects persisted even after households stopped receiving Opower reports. ${ }^{916}$ Thus, transparency and the array of energy and environmental metrics and benchmarks now available offers a powerful tool for progress toward sustainability that goes way beyond regulatory requirements.

\footnotetext{
Analysis, 6 SUSTANABLITY 7807, 7808 (2014) (using the EPI to identify key determinants of environmental performance, including institutional factors such as corruption).

310 See John C. Bertot, Paul T. Jaeger \& Justin M. Grimes, Using ICTs to Create a Culture of Transparency: E-Government and Social Media as Openness and Anti-Corruption Tools for Societies, 27 GOV'T INFO. Q. 264, 264 (2010) (describing how citizens have harnessed new information and communication technologies to push for greater transparency in government and firm decision making).

311 Renee Cho, Data's Power to Spur Environmental Progress, EARTH Inst.: STATE Of THE PLANET (Feb. 14, 2012), https://perma.cc/4G6G-SP2T (describing how South Korea responded to its poor air quality ranking on the Environmental Sustainability Index by creating new and successful air pollution programs).

312 Bryan Bollinger \& Kenneth Gillingham, Peer Effects in the Diffusion of Solar Photovoltaic Panels, 31 MARKETING SCI. 900 (2012) (finding the installation of solar increases the likelihood of solar adoption among neighboring households); Yueming Qiu, Shuai Yin \& Yi David Wang, Peer Effects and Voluntary Green Building Certification, SuSTAINABILITY, July 2016, art. no. 631, at 12 (finding peer effects for green building certificates).

313 Kenneth Gillingham, Bryan Bollinger \& Hilary Staver, Social Learning and Solar Photovoltaic Adoption: Evidence from a Field Experiment 1 (Dec. 10, 2015) (draft manuscript), https://perma.cc/R3PL-68E2 (showing that Connecticut's Solarize program increased residential solar adoption rates by "leverag[ing] social learning and peer interactions").

314 Hunt Allcott \& Todd Rogers, The Short-Run and Long-Run Effects of Behavioral Interventions: Experimental Evidence from Energy Conservation, 104 AM. ECON. REv. 3003, 3004 (2004). For a concise summary of this research, see Hunt Allcott \& Todd Rogers, Opower: Evaluating the Impact of Home Energy Reports on Energy Conservation in the United States, ABDUl LATIF JAMEel POVERTY ACTION LAB, https://perma.cc/R86J-ECHE (last visited Feb. 25, 2017).

315 Allcott \& Rogers, supra note 314 , at 3007 .

316 Id. at 3034 .
} 


\section{B. Science and Knowledge}

We know much more about many things today than we did in 1970. Scientific advances have allowed us to better understand the sources of environmental public health threats and ecosystem risks. ${ }^{317}$ We also have strengthened our capacity to map the causal relationships from sources to harms and to identify solutions to environmental problems. ${ }^{318}$ Fundamentally, the internet and Information Technology breakthroughs give the science community access to a vastly wider knowledge base and much more fine-grained data-strengthening in dramatic ways the empirical foundations and analytic underpinnings for environmental decision making. ${ }^{319}$ And over time, analytic rigor will improve operational results.

Nevertheless, significant uncertainties remain - and will remain. The state of our knowledge will continue to evolve. Some elements of what we thought we knew about pollution problems will be found to be untrue or incomplete. Our theories will need to be refined and revised. This is the nature of science. But as our zone of uncertainty ${ }^{320}$ shrinks, we need a more flexible and nimble structure of environmental protection that can bring new understanding to bear in the policy arena more quickly. ${ }^{321}$

\section{Changed Role of Government}

Even if slower economic growth and persistent budget crises did not make scaled-back environmental agencies a fiscal imperative, the broader trend toward smaller government that has been underway for more than three decades suggests that the time is right for a re-examination of our

317 Yuqiong Liu et al., Linking Science with Environmental Decision Making: Experiences from an Integrated Modeling Approach to Supporting Sustainable Water Resources Management, 23 ENVTL. MODELING \& SOFTWARE 846, 846 (2008) ("Science is increasingly being called upon to provide information for complex environmental decision making. However, despite recent remarkable advances in environmental science with growing availability of relevant knowledge, data, and information, how science can best support environmental decision making remains an outstanding question." (citations omitted)).

318 Perhaps most notably, scientists have conclusively determined that humanity's economic activities are causing the globe to warm. See InTERgovernmental PANEL ON Climate Change, Climate Change 2014 Synthesis RePort 4 (Rajendra K. Pachuari et al. eds., 2014) ("Anthropogenic greenhouse gas emissions ... are extremely likely to have been the dominant cause of the observed [global] warming since the mid-20th century.").

319 Olivier Dumon, How the Internet Changed Science Research and Academic Publishing, Creating the New Research Economy, HuFFINGTON POST (Jan. 5, 2013), https://perma.cc/28K95UM4 (documenting the effects of the internet on academic research and scientific collaborations).

320 Esty, Optimal Governance, supra note 204, at 1519 \& tbl.1 (demonstrating how a reduced zone of uncertainty makes political consensus easier).

321 As Jonathan Wiener aptly notes: "Successful environmental policy . . . depends on good information about the extent of problems and about the relative performance of alternative policy measures." Jonathan B. Wiener, Towards an Effective System of Monitoring, Reporting and Verification, in TOWARDS A WORKABLE AND EFFECTIVE ClIMATE REGIME 183, 183-84 (Scott Barrett et al. eds., 2015). 
environmental protection strategies. ${ }^{322}$ Even those who believe in a robust role for government in delivering "public goods" recognize the limits of the 1960s Great Society Era belief in government action-particularly federal government action-as the key point of leverage for social progress and have come to accept more modest goals for what government can do. ${ }^{323}$ The twin realities of budget constraints and pressure for a narrower government role provide a push for regulatory reform alongside the pull of potential new models of environmental protection. ${ }^{324}$ Indeed, the trend toward a reduced scale of government activity and spending along with pressure for more action on issues such as climate change and other unresolved environmental threats can only be reconciled with a reconfigured governmental approach to the critical issues that allows more to get done with fewer resources. ${ }^{325}$

Managing pollution under the command-and-control regulatory model is a complex and cumbersome task that requires the government to find environmental problems, map the sources of harm, identify potential policy responses, specify solutions including detailed technology prescriptions, guide the regulated community's implementation of the chosen interventions, inspect facilities, track pollution stocks as well as flows, and take enforcement action against those out of compliance. Moving to a system based on price signals could relieve much of the burden on governments to be the central actor on the sustainability stage ${ }^{326}$ In addition, a concerted policy focus on creating "green lights" that engage other institutions and individuals in the work of delivering better environmental outcomes makes possible a reduced role for government. ${ }^{327}$

Under the 21st century sustainability model I propose, rather than defining best available technologies or trying to set industry-specific emissions standards, EPA would concentrate its efforts on establishing public-health-based emissions thresholds and pollution prices. This new focus would require investment of considerable resources initially, but

322 For example, the federal government workforce has steadily shrunk since the $1960 \mathrm{~s}$ and 1970s. Historical Federal Workforce Tables: Total Government Employment Since 1962, U.S. OFF. PERSONNEL MGMT., https://perma.cc/6RM8-QFJR (last visited Feb. 25, 2017).

323 See Coglianese, supra note 156, at 1 (describing the growing interest in using "publicprivate partnerships as major tools for making progress in environmental protection and risk management").

324 David L. Markell \& Robert L. Glicksman, A Holistic Look at Agency Enforcement, 93 N.C. L. REV. 1, 53 (2014) (noting a shift in EPA enforcement strategies in response to recent budget cuts).

325 See Howard A. Latin, Climate Change Regulation and EPA Disincentives, 45 ENVTL. L. 19, 57 (2015) (arguing that underfunding and understaffing has limited EPA's ability to develop adequate climate regulations); James Salzman, J.B. Ruhl \& Jonathan Remy Nash, Environmental Law in Austerity, 32 PACE ENVTL. L. REv. 481, 481-84 (2015) (positing that "[f]iscal austerity has become the new norm" for EPA and examining how budgetary sequestration has shaped and will shape environmental regulation in the United States).

326 Gayer \& Horowitz, supra note 205, at 215 (noting that "[m]arket approaches are almost always less costly to administer" than command-and-control regulations.).

327 See Salzman, Ruhl \& Nash, supra note 325, at 486 (suggesting that, in response to budgetary constraints, EPA may seek to outsource environmental regulation and enforcement to states and nonstate actors). 
should demand less staff effort and funding over time. ${ }^{328}$ Indeed, if the government establishes appropriate incentives for others to contribute to data generation and analysis, it should be able to share much more broadly the analytic burden of environmental protection. ${ }^{329} \mathrm{~A}$ commitment to reinvigorated environmental federalism would position EPA to share the work of pollution control and natural resource management with state and local governments, as well as land trusts and other entities. ${ }^{330}$

In this regard and as discussed above, governments have a major data clearinghouse role to play-defining reporting requirements, establishing the methodologies for various required metrics, and validating results. ${ }^{331}$ In providing a trusted framework of sustainability metrics, governments can spur improved performance by all those who make critical environmental decisions-most notably the corporate leaders who decide which products to make and how to make them. ${ }^{302}$ The same benchmarking strategy and resulting incentives for environmental progress can be used to engage communities, NGOs, and individuals as well. ${ }^{333}$ Indeed, information

328 See, e.g., Stewart, Regulation, Innovation, and Administrative Law, supra note 73, at 1327 ( $[\mathrm{A}] \mathrm{n}$ emission fee system would promote a least-cost allocation of control burdens without the substantial administrative costs and disincentives involved in attempting to achieve such an allocation under a regulatory approach." (footnote omitted))

329 See generally Esty, Information Age, supra note 127.

330 See generally David L. Markell, The Role of Deterrence-Based Enforcement in a 'Reinvented' State/Federal Relationship: The Divide Between Theory and Reality, 24 HARV. ENVTL. L. REV. 1, 30-43 (2000) (describing the existing relationship between EPA and states with respect to environmental compliance and enforcement); see also David R. Hodas, Enforcement of Environmental Law in a Triangular Federal System: Can Three Not Be a Crowd When Enforcement Authority is Shared by the United States, the States, and Their Citizens?, $54 \mathrm{MD}$. L. REv. 1552, 1651-67 (1995) (arguing that citizen enforcement-namely through citizen suits-is necessary to the successful enforcement of the Clean Water Act).

331 Applegate, supra note 231, at 1392 ("Institutionally, government agencies are well positioned to assemble and organize large amounts of information from studies published in scattered publications, submitted through applications and reporting requirements, and collected from monitoring and inspection."); Daniel C. Esty \& Maria H. Ivanova, Revitalizing Global Environmental Governance: $A$ Function-Driven Approach, in REvitalizIng GLoBaL ENVIRONMENTAL Governance: A FunCtion-Driven APPROACH 181, 195-96 (Daniel C. Esty \& Maria H. Ivanova eds., 2002) (making the case for a global information clearinghouse in the international environmental context).

332 Daniel C. Esty, Revitalizing Environmental Federalism, 95 MiCH. L. REV. 570, 622-23 (1996) [hereinafter Esty, Environmental Federalism] (arguing for the creation of a "National Institute for the Environment (NIE). An NIE, like the National Institutes of Health (NIH), would serve as a centralized data gathering and analysis mechanism. It would offer scientific support to regulating jurisdictions that would use the data and information provided to set their own standards. An NIE also could develop model legislation as one way of consolidating diverse information into a form that would be useful to regulating jurisdictions. Such a mechanism would go a considerable distance toward addressing the capacity problem that historically has plagued state-based environmental regulation."). Notably, other federal agencies, such as the U.S. Department of Housing and Urban Development, already serve as recognized information clearinghouses. David Zaring, Best Practices, 81 N.Y.U. L. REv. 294, 341 (2006).

333 A prime example is the Appliance and Equipment Standards program run by the United States Department of Energy (DOE). Office of Energy Efficiency \& Renewable Energy, U.S. Dep't of Energy, Appliance and Equipment Standards Program, ENERGY.gov, https://perma. cc/X897-CB89 (last visited Feb. 25, 2017). 
disclosure emerges as a core element of the "green light" structure of incentives that I believe will undergird the 21 st century sustainability model.

In addition to serving as data aggregators and validators, governments might also play an expanded role in the diffusion of innovation and the dissemination of best practices. ${ }^{334}$ Simply by providing tools for benchmarking performance, governments can highlight what works in the sustainability realm and thus guide the behavior of individuals, companies, communities, states or provinces, and even other nations. ${ }^{335}$ A number of entities play this role already-and might provide models to be expanded. ${ }^{336}$ The Organisation for Economic Co-operation and Development (OECD) represents one such example with a number of policy ideas and sustainability practices having been incubated in its conferences and conversations. $^{337}$ The recent launch of a secretariat to support an annual Clean Energy Ministerial Meeting under the auspices of the OECD and its sister organization, the International Energy Agency, offers the prospect of faster international dissemination of emerging best practices across the energy domain. ${ }^{338}$

But any effort to redefine government's environmental role for the 21st century should go further. In the face of limited resources, much of what needs to be done to protect the environment can be done with partners from outside the government. ${ }^{32}$ In particular, private capital can be deployed to finance needed environmental infrastructure investments. ${ }^{340}$ But to induce

334 Esty, Information Age, supra note 127, at 156-62.

335 For example, DOE has created the Standard Energy Efficiency Data (SEED) Platform, which "provides public agencies and other organizations with a standardized but flexible, costeffective, secure, enterprise data platform to manage portfolio scale building performance data from a variety of sources." See Office of Energy Efficiency \& Renewable Energy, U.S. Dep't of Energy, Standard Energy Efficiency Data Platform, ENERGY.Gov, https://perma.cc/A76J-ELWK (last visited Feb. 25, 2017).

336 The Leadership in Energy and Environmental Design (LEED) Standard, for example, is a benchmark system for sustainable buildings that was designed by a nonprofit organization, the United States Green Building Council. See LEED, U.S. GREEN BULDING COUNCL, https://perma.cc/CA66-RPC4 (last visited Feb. 25, 2017). More recently, another nonprofit organization, the Environmental Defense Fund (EDF), developed a system of standardized energy efficiency protocols to help investors calculate returns on investments in energy efficiency retrofits. See Matt Golden, EDF's Energy Efficiency Protocols Gain Traction, ENvTL. DEF. FUND.: ENERGY EXCHANGE (Dec. 19, 2013), https://perma.cc/6K3W-JLN9.

337 See, e.g., Org. For ECON. CO-OPERATION \& DEv., GoING GreEn: Best Practices for SUSTAINABLE PROCUREMENT (2015), https://perma.cc/9XSA-U9AK; ORG. FOR ECON. CO-OPERATION \& Dev., Promoting Sustainable Consumption: Good Practices In OECD Countries (2008), https:/perma.cc/SB34-KNES.

338 Press Release, Int'l Energy Agency, Clean Energy Ministerial Secretariat Finds New Home at the IEA (June 15, 2016), https://perma.cc/C38M-FJST. See generally ClEAN ENERGY Ministerial, FRAMEWORK FOR THE ClEAN ENERgY MiNISTERIAL (2016), https:/perma.cc/84YSUHCG.

339 INT'L RENEwable Energy Agency, Unlocking Renewable EnERgy INVESTMENT: The ROLE OF RISK MITIGATION AND STRUCTURED FINANCE 12 (2016), https://perma.cc/M9YA-3DJN (indicating that "private finance will have to supply the lion's share of new investment in renewables" around the globe).

340 Michael Mendelsohn \& David Feldman, Nat'l Renewable Energy LaB., NREL/TP-6A2058315, Financing U.S. Renewable Energy Projects through PUblic Capital Vehicles: 
this flow of funds, the government must recognize that one of its new roles is to "de-risk" private environmental investments in priority projects. ${ }^{341}$ Movement toward a clean energy future in particular will require hundreds of billions of dollars of research and development spending and ramped-up investment in renewable power technologies, electricity storage, distributed generation, and smart grid infrastructure. ${ }^{342}$ The government cannot commit resources at the scale required nor is it well positioned to be the investor in many circumstances. ${ }^{343}$ But it can channel private capital with the structure of incentives it puts in place. ${ }^{344}$

The partnerships required for ongoing environmental success go beyond those related to finance and investment. A fundamental rethinking of the division of labor among federal, state, and local authorities is in order. To the extent that environmental circumstances diverge, preferences vary by location, and the geographic extent of spillovers is small, it makes sense to shift primary regulatory responsibilities to state- or even municipal-scale authorities. ${ }^{345}$ Likewise, some of the work of environmental data gathering, issue spotting, and problem solving for global scale issues, including ozone

QUALITATIVE AND QUANTTTATIVE BENEFITS 21 (2013) (describing various mechanisms for using public dollars to leverage private investments in renewable energy projects).

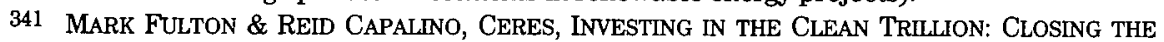
CLEAN ENERGY INVESTMENT GAP 22, 55 (2014) (underscoring the need to incentivize private investments in renewable energy and highlighting governments' important role in de-risking clean energy investments); KEN BERLIN ET AL., BROOKINGS INST., STATE ClEAN ENERGY FinaNCE BANKS: NEW INVESTMENT FACILITIES FOR CLEAN ENERGY DEVELOPMENT 2 (2012) (discussing the importance of government funding in reducing the finance risks associated with low carbon technologies); JefFrey SCHUB ET AL., NAT. RES. DEF. COUNCIL ET AL., GREEN \& RESILIENCE BANKS 4 (2016) (discussing the important role that Green Investment Banks can play in raising private capital for clean energy projects and, ultimately, closing the climate finance gap); see also Esty, Regulatory Transformation, supra note 110, at 409.

342 INT'L ENERgy AGENCY, GLOBAL GAPS IN ClEAN ENERgY RD\&D: UPDATE AND RECOMMENDATIONS FOR INTERNATIONAL COLLABORATION 14 (2010) (estimating that public sector spending on research, development, and deployment (RD\&D) of clean energy technologies needs to increase by two to five times 2010 levels); INT'L ENERGY AGENCY, ENERGY TECHNOLOGY Perspectives: Scenarios \& Strategies to 205053 (2010) (projecting that investments in lowcarbon energy technologies will need to increase 2010 levels of $\$ 165$ billion per year to $\$ 750$ billion per year by 2030 , before rising to over $\$ 1.6$ trillion year from 2030 to 2050 ).

343 Jonathan H. Adler, Eyes on a Climate Prize: Rewarding Energy Innovation to Achieve Climate Stabilization, 35 HARV. ENVTL. L. REV. 1, 37 (2011) ("Government regulators "have a relatively poor record in picking which future technologies will best succeed in achieving a particular objective." (quoting Gary E. Marchant, Sustainable Energy Technologies: Ten Lessons from the History of Technology Regulation, 18 WIDENER L.J. 831, 836 (2009)).

344 Whitney Angell Leonard, Note, Clean Is the New Green: Clean Energy Finance and Deployment Through Green Banks, 33 YALE L. \& POL'Y REV. 197, 199 (2014) (discussing the successes of green banks at directing private capital to renewable energy and energy efficiency projects); Jerome Reichman, Arti K. Rai, Richard G. Newell \& Jonathan B. Wiener, Intellectual Property and Alternatives: Strategies for Green Innovation (Chatham House, Energy, Env't \& Dev. Prog. Paper No. 08/03, Dec. 2008), https://perma.cc/MGV4-CYV7 (discussing how intellectual property rights and alternatives to intellectual property rights-including patent pools, liability rules, and research prizes-might be used to spur climate-related innovation).

345 Butler \& Macey, supra note 8, at 27 (arguing that, per the matching principle, "environmental regulation has been centralized beyond any possible justification"). 
layer depletion, ocean ecosystem health, and climate change, can be done by international organizations. ${ }^{346}$

More generally, expanded public-private partnerships will be an important element of the sustainability strategy of the future. ${ }^{347}$ Some roles that have historically been played by governments-such as environmental education-may need to be shared with nongovernmental entities. ${ }^{348}$ Perhaps, for example, nature centers will be managed by the Audubon Society or The Nature Conservancy rather than state parks departments. Limited government resources will need to be focused on essential governmental functions. For all other activities, partnerships must be the watchword.

Government will continue to need to correct market failures and thus play a leading role in activities essential to environmental progress where the private sector will otherwise under-invest. ${ }^{349}$ This logic argues for an ongoing government role in funding basic research and supporting high-risk projects where the scale of investment is too large for the private sector to do on its own. ${ }^{350}$ Carbon capture and storage (CCS), for example, will probably not be developed unless governments partner with energy companies-or put a much higher price on greenhouse gas emissions, which would increase the payoff to entrepreneurs delivering a breakthrough in this technology. ${ }^{351}$

346 See Esty, Environmental Federalism, supra note 332, at 623 (arguing that "most aspects of environmental research and analysis show significant economies of scale"); Esty \& Ivanova, supra note 331 , at 195 (making the case for a global information clearinghouse in the international environmental context).

347 For examples of innovative public-private partnerships in the sustainability space, see Mike Hower, 5 Public-Private Partnerships Pushing the Sustainability Envelope, GreEnBiz (Mar. 4, 2015), https://perma.cc/EA2C-GR7C.

348 As discussed earlier, advancements in information technologies are working to democratize the collection and analysis of environmental data. As a result, nongovernment actors are increasingly becoming sources of environmental information and environmental education. See supra Part V.A.3.

349 Robert M. Margolis \& Daniel M. Kammen, Underinvestment: The Energy Technology and $R \& D$ Policy Challenge, 285 SCIENCE 690 (1999) (arguing that "the energy sector dangerously underinvests relative to other technology-intensive sectors of the economy" and calling for a significant increase in international energy research and development funding).

350 It is well established that research generates positive externalities. Specifically, knowledge is non-rivalrous in that use by one person does not prevent use by the other. As a result, innovators often cannot fully appropriate the returns to their research, since knowledge relating to their invention will almost inevitably leak (free of charge) to competitors and the outside world. These knowledge spillovers are particularly large for basic research, which, by definition, addresses fundamental questions of nature and science--and therefore is not easily commercialized. Browyn H. Hall, Jacques Mairesse \& Pierre Mohnen, Measuring the Returns to $R \& D$, in 2 HANDBOOK OF THE ECONOMICS OF INNOVATION 1033, 1065-82 (2010) (reviewing the theoretical and empirical evidence of knowledge spillovers, and noting that knowledge spillovers tend to be larger for basic research than applied research).

351 See Lincoln L. Davies, Kirsten Uchitel \& John Ruple, Understanding Barriers to Commercial-Scale Carbon Capture and Sequestration in the United States: An Empirical Assessment, 59 ENERGY POL'Y 745, 749 (2013) (A survey of 229 carbon capture sequestration experts indicated that high technology costs and "lack of a [carbon] price signal" were main barriers to the commercialization of CCS); Dennis Y.C. Leung et al., An Overview of Current 


\section{Business Leadership}

In the 20th century, business activities, most notably those of largescale industrial production, were seen as the fundamental source of environmental problems. ${ }^{352}$ As new pollution control requirements came into place in the $1970 \mathrm{~s}$, many companies resisted these regulations. ${ }^{363}$ Today, some companies and a few industries continue to balk at every proposal for strengthened environmental rules and to lobby against all such changes, but most corporate leaders recognize the value of these rules and understand the broad base of public support for clean water and air, reduced chemical exposure, and control of greenhouse gas emissions. ${ }^{364}$ In the face of a reduced government role, the public's expectations about what the private sector can do to produce a sustainable future are rising. ${ }^{355}$ Interest in corporate sustainability comes not just from environmental NGOs but from customers, employees, community leaders, and (increasingly) investors. ${ }^{366}$ Under heightened scrutiny, companies have emerged as critical contributors to sustainability. ${ }^{357}$

Status of Carbon Dioxide Capture and Storage Technologies, 39 RENEWABLE \& SUSTAINABLE ENERGY REVS. 426, 439 (2014) ("There are multiple hurdles to CCS deployment that need to be addressed in the coming years, including the absence of a clear business case for investment in $\mathrm{CCS}$, and the absence of robust economic incentives to support the additional high capital and operating costs associated with CCS.").

352 E.g., WORLD COMM'N ON ENV'T \& DEV., supra note 1, at 206.

353 Robert L. Glicksman, Anatomy of Industry Resistance to Climate Change: A Familiar Litany, in ECONOMIC Thought AND U.S. Climate Change Policy 83, 89-90 (David Driesen ed., 2010) (describing industry pushback to early environmental statutes).

354 Peter Senge ET al., THE NEcessary Revolution: How Individuals and ORganizations ARE WORKIng TOGETHER TO CREATE A SUSTAINABLE WORLD 4 (2010) (arguing that firms must rethink their approach to the environment and documenting leading companies that have already begun to embed sustainability into their business model); JAN-OLAF WILLUMS, THE Sustainable Business Challenge: A BrIEFIng For TOMORRow's Business Leaders 87 (1998) (observing the mainstreaming of environmental values and concerns in the corporate world); Michael P. Vandenbergh \& Jonathan A. Gilligan, Beyond Gridlock, 40 COLUM. J. ENVTL. L. 217, 218-19 (2015) (documenting an array of climate-mitigation actions being taken by major corporations across the globe).

355 Thomas P. Lyon \& John W. Maxwell, Corporate Social Responsibility and the Environment: A Theoretical Perspective, 2 REv. ENVTL. ECON. \& Pol'Y 240, 243-45 (2008) (discussing the demand-and supply-side pressures for companies to become more socially responsible and environmentally friendly); James Epstein-Reeves, Consumers Overwhelmingly Want CSR, FORBES: CSR BLOG (Dec. 15, 2010), https://perma.cc/D722-SA6T (public opinion surveys showing broad support for corporate social responsibility); see also Christopher F. Schuetze, Social Responsibility and M.B.A.'s, N.Y. TTMES (Oct. 21, 2013), https://perma.cc/P8T8ZQS3 (MBA students are increasingly demanding more courses in sustainable business practices).

356 EsTY \& Simmons, supra note 297, at 63-68; Sheila Bonini \& Anne-Titia Bové, Sustainability's Strategic Worth: McKinsey Global Survey Results, McKINSEY \& Co. (July 2014), https://perma.cc/U4L2-PSYE.

357 See generally StEPHAN SCHMIDHEINY \& FEDERICo ZORRaQUín, FinaNCING Change: THE FInANClal COMmunity, ECO-EFFiciency, AND Sustainable DeVElopment (1996); see also Vandenbergh \& Gilligan, supra note 354 , at 226 (stating that private climate initiatives alone can reduce emissions by roughly a gigaton of carbon dioxide per year between 2016 and 2025). 
In addition, as fresh thinking and the capacity to deliver on-the-ground results have become more central to environmental progress, the business world's innovation capabilities and action orientation are now seen as important mechanisms for delivering progress on environmental challenges. ${ }^{368}$ For this potential to be fully unleashed, governments need to structure incentives to engage America's entrepreneurial talents and to reward environmental problem solving. Fewer technology mandates and more price signals that promise marketplace rewards for breakthrough products are fundamental to this repositioning of business as a driver of sustainability.

Even without a carefully constructed regime of green lights, companies have come to recognize the "green to gold" opportunities that can arise from bringing a focus on energy and environmental issues to day-to-day corporate strategy. ${ }^{369}$ Across the country and the world, thousands of businesses are saving money by finding ways to be more energy efficient. ${ }^{360}$ By reducing scrap and waste, they enhance their resource productivity-and cut costs. ${ }^{361}$ And many are making money by bringing goods and services to the marketplace that deliver solutions to their customers' environmental problems. ${ }^{362}$ Some corporate leaders have gone so far as to commit their companies to solving society's problems as a core dimension of their business strategy. ${ }^{363}$ Dow Chemical, for example, has set itself a goal of introducing major sustainability breakthroughs as a way to drive revenue growth. ${ }^{364}$

It is, moreover, in the nature of profit-making enterprises to respond to incentives. So the green lights strategy that undergirds my vision for 21st century sustainability needs to focus on the opportunities to draw business into the work of environmental protection in general and the transition to a clean energy future in particular. Success in this regard will require an expanded policy toolkit. As noted above, particular emphasis needs to be placed on incentives that channel private capital into priority environmental

358 See generally SustaINABle InVESTING: THE ART OF LONG-TERM PERFormance (Cary Krosinsky \& Nick Robins eds., 2008).

359 ESTY \& SIMMONS, supra note 297, at 32.

360 Global investments in energy efficiency resources are growing fast, reaching $\$ 300$ billion per year in 2015. Steven Nadel, 2015 was a Good Year for Energy Efficiency. 2016 Could Be Even Better, AM. COUNCIL FOR AN ENERgy-EFFICIENT ECON.: Blog (Jan. 01, 2016), https://perma.cc/G57Q-3W7K.

361 Sindya N. Bhanoo, Those Earth Friendly Products? Turns Out They're Profit-Friendly as Well, N.Y. TIMES, June 12, 2010, at B3; see also ESTY \& SimMONS, supra note 297, at 32.

362 E.g., SENGE ET AL., supra note 354, at 297-98.

363 See generally David A. Lubin \& Daniel C. Esty, The Sustainability Imperative: Lessons for Leaders from Previous Game-changing Megatrends, HARv. Bus. REv., May 2010, at 42.

364 Id. at 47 ("As the vision expands further, sustainability innovations become the source of new revenues and growth. Dow's sweeping 2015 Sustainability Goals, designed to drive innovation across its many lines of business, yielded new products or technology breakthroughs in areas from solar roof shingles to hybrid batteries. The core business, which had traditionally relied on commodity chemicals, has shifted toward advanced materials and high-tech energy opportunities.") For more recent goals, see generally 2025 Sustainability Goals, Dow, https://perma.cc/WB8G-G6Z5 (last visited Feb. 25, 2017). 
investments, encourage and target private-sector technology breakthroughs, promote information disclosure as well as improved science and analysis, ensure accurate sustainability metrics and performance benchmarking, and, most importantly, ensure that businesses that deliver goods and services that contribute to a sustainable future get rewarded in the marketplace. ${ }^{365}$ The central policy step in this regard would be a move toward a regulatory framework of price signals that provide continuous incentives to reduce harms and promote improved environmental results. ${ }^{366}$

\section{E. Changed Roles of Individuals}

Not only have the roles of governments and business changed in ways that need to be reflected in any new Sustainability Model, so too has the capacity for individuals to shape environmental outcomes. The 20th century approach to environmental progress, centered on government regulations, engaged the public largely as citizens voting for representatives who would decide on the framework of environmental laws. Today, individuals can play a number of additional roles beyond that of voter. ${ }^{367}$

A growing phalanx of green consumers are bringing sustainability factors to bear in their purchasing decisions. Environmentally advantaged products have seized market share in many industries. Demand for organic food, for instance, has boomed. ${ }^{368}$ In parallel, Whole Foods Market, with its emphasis on fresh, natural, and organic products has experienced extraordinary growth over the past decade. ${ }^{369}$ Many other products and services are being similarly transformed. Every city now has a "green" dry cleaner seeking to draw customers with a promise of clean clothes without a dose of trichloroethylene (TCE), a carcinogen that traditional dry cleaning

365 See supra Part V.C.

366 Professors Aldy and Stavins nicely summarize the limitations of command-and-control mechanisms in incentivizing pollution-abatement innovation:

Beyond considerations of static cost-effectiveness, conventional standards would not provide dynamic incentives for the development, adoption, and diffusion of environmentally and economically superior control technologies. Once a firm satisfies a performance standard, it has little incentive to develop or adopt cleaner technology. Regulated firms may fear that if they adopt a superior technology, the government may tighten the performance standard. Technology standards are worse than performance standards in inhibiting innovation since, by their very nature, they constrain the technological choices available.

Joseph E. Aldy \& Robert N. Stavins, The Promise and Problems of Pricing Carbon: Theory and Experience, 21 J. ENv'T \& DEv. 152, 154 (2012).

367 Michael E. Milakovich, The Internet and Increased Citizen Participation in Government, 2 J. EDEM. \& OPEN GOV'T 1, 3 (2010) (noting that information and communication technologies "have become highly advantageous to citizen activists, NGOs, and new social movements that seek to challenge and occupy new public spaces").

368 See Organic Market Overview, ECON. RES. SERv., U.S. DEP'T AGRIC., https://perma.cc/ SY95-ATAZ (last visited Feb. 25, 2017) (showing that total sales of U.S. organic food more than doubled between 2005 to 2014 ).

369 Whole Food's sales have grown from roughly $\$ 93$ million in 1991 to $\$ 14.2$ billion in 2014 . WHOLE FOODS MARKET, 2014 ANNUAL REPORT 4 (2014), https://perma.cc/S7BW-PEAP. 
relies upon. ${ }^{370}$ And major consumer goods companies, such as Unilever, are reporting higher sales rates for their green or "sustainable" brands than for conventional goods. ${ }^{371}$

Demographic shifts seem likely to accelerate this trend. Indeed, young people are much more likely to seek out green products or services-and much more willing to pay a premium for the sustainability attributes they want. $^{372}$ As the number of so-called lifestyle of health and sustainability (LOHAS) consumers rise, more and more companies will work sustainability into their marketplace pitch, delivering additional sustainability gains-all without regulatory mandates. ${ }^{373}$

As explained above, the rise of investors interested in making sustainability a factor in their choices of stocks or bonds represents another vector of extended individual impact. ${ }^{374}$ This trend seems likely to expand as environmentally conscious "millennials" become a greater percentage of the wealth holders. ${ }^{375}$ And, as discussed earlier, better data on corporate

370 See, e.g., Rebecca Kahlenberg, Not Just Pizza: Goods and Services Come to Your Door, WASH. POST (Feb. 28, 2004), https://perma.cc/C57W-SDS5 (describing the growth of Zoots Corp., an eco-friendly dry cleaner chain, in the Washington, D.C. area). Meanwhile, the market for green cleaning products - such as Seventh Generation dish washing soap-has been growing at a strong clip of about 20 percent annually in recent years. Vesela Veleva, The 3 Challenges Facing Green Cleaners, GREENBIZ (July 22, 2011), https://perma.cc/9FWU-DWXT.

371 Sustainable Living Brands Leading Unilever, UNILEver (May 20, 2016), https://perma. cc/YP5B-3JDH (reporting that the company's "sustainable living brands are growing 30\% faster than the rest of [its] business and delivered nearly half of [its] total growth in 2015").

372 In a recent survey of global consumers, nearly three quarters of respondents aged fifteen to twenty were "willing to pay more for products and services that come from companies who are committed to positive social and environmental impact...." Green Generation: Millennials Say Sustainability is a Shopping Priority, NIELSEN (Nov. 5, 2015), https://perma.cc/AS2R-KJV3; see also Gwynne Rogers, The Rise of Generation $Y$ in the Sustainable Marketplace, GuARDIAN: SUSTAINABLE BUSINESS (Feb. 4, 2013), https://perma.cc/8U2K-KZ4S ("Generation Y is showing ... a willingness to pay for sustainable products and interest in premium sustainable products...."); Ricardo Sellers-Rubio \& Juan Luis Nicolau-Gonzalbez, Estimating the Willingness to Pay for a Sustainable Wine Using a Heckit Model, 5 WINE ECON. \& POL'Y 96, 103 (2016) (finding empirical evidence that consumers are willing to pay a premium for sustainably produced wine).

373 Consider, for example, Unilever's ambitious Sustainable Living Plan. The Unilever Sustainable Living Plan, UNILEVER, https://perma.cc/9JGQ-5S69 (last visited Feb. 25, 2017) ("The Unilever Sustainable Living Plan is our blueprint for achieving our vision to grow our business, whilst decoupling our environmental footprint from our growth and increasing our positive social impact." ).

374 As evidence of the mainstreaming of sustainability principles into the investment world, the Principles for Responsible Investment, which receives support from the United Nations, have been adopted by more than 1,400 signatories in 2015, including 336 investment managers and asset owners, representing nearly $\$ 59$ trillion in assets. PRINCIPLES FOR RESPONSIBLE INV., ANNUAL REPORT 2015: FROM AWARENESS TO IMPACT 2, 15, 31 (2015), https://perma.cc/LQC4XEMG.

375 A survey of individual investors conducted by Morgan Stanley's Institute for Sustainable Investing found that millennials were substantially more interested in sustainability than older respondents. Maryann Busso, Millennials Are Coming and They Want Sustainable Investments, BLOOMBERG (Oct. 26, 2016), https://perma.cc/7XFY-X9BU. Indeed, more than eight in ten millennials expressed interest in sustainable investing, and millennials were "twice as likely to invest in a stock or a fund if sustainability is part of the value-creation thesis." Id. 
sustainability performance-perhaps supported by new government reporting requirements ${ }^{376}$ - could accelerate the shift of capital toward more sustainable companies. The key to expanded sustainability-driven capital flows is investor confidence that they can differentiate among leading and lagging companies-and understand more clearly when sustainability leadership will pay off with superior stock market returns. ${ }^{377}$ Thus, the potential for individuals to drive change as investors depends on government providing a framework of trusted corporate sustainability metrics on which market participants can rely. ${ }^{378}$

Individuals not only want more sustainability metrics, they are also generating such data with their social media commentary on companies and products. Just as Ebay or Etsy build confidence in their online marketplaces with ratings on product sellers, similar data on environmental performance are starting to be provided by companies such as GoodGuide, ${ }^{379}$ Environmental Working Group (EWG), ${ }^{380}$ B Corp, ${ }^{381}$ Monterey Bay Aquarium Seafood Watch, ${ }^{382}$ and the Eat Well Guide ${ }^{389}$ to name a few.

376 In 2016, SEC issued its Regulation S-K Concept Release, which solicited public input on how to reform and modernize the disclosure requirements in Regulation S-K. Business and Financial Disclosure Required by Regulation S-K, 81 Fed. Reg. 23,916 (proposed Apr. 22, 2016) (to be codified at 17 C.F.R. pts. 210, 229, 230, 232, $239 \& 249$ ). Notably, the release specifically requested feedback on whether and how to require companies to report sustainability-related materials. Id. at 23,970 . The proposal noted, for example, the increasing demand for disclosure of climate change risks. Id. at 23,971 .

377 Esty \& Cort, supra note 298, at 18, 38.

378 Prior research shows that sustainability metrics are often weak predictors of environmental performance and tend to suffer from standardization and transparency problems. See, e.g., Aaron Chatterji \& David Levine, Breaking Down the Wall of Codes: Evaluating Non-Financial Performance Measurement, CAL. MGMT. REv., Winter 2006, at 29, 31 (describing problems with the reliability, validity, and comparability of social responsibility metrics); Aaron K. Chatterji, David I. Levine \& Michael W. Toffel, How Well Do Social Ratings Actually Measure Corporate Social Responsibility?, 18 J. ECON. \& MGMT. STRATEgy 125, 165 (2009) (questioning the validity of sustainability metrics produced by one leading data analytics firm).

379 GoodGuide is a web-based platform that has rated over 250,000 products on their health effects. GoODGUIDE, https://perma.cc/9J7L-ECJS (last visited Feb. 25, 2017); Top Searches of 2015-Products, Ingredients \& Brands, GoODGUIDE BLOG (Jan. 6, 2016), https://perma.cc/97TH$2 \mathrm{E} 58$.

380 EWG provides environmental and health rankings for and guides to thousands of different consumer products, including cosmetics, food, and cleaning products. About EWG'S Guide to Healthy Cleaning, ENVTL. WORKING GROUP, https://perma.cc/6RNX-HNYL (last visited Feb. 25, 2017); Consumer Products, ENVTL. WORKING GrouP, https://perma.cc/F4TF-K68W (last visited Feb. 25, 2017).

381 B Corp has created a rating system that ranks small and mid-sized companies in terms of their social and environmental footprint. Best for the World 2015, B LAB, https://perma.cc/ELC7 46DP (last visited Feb. 25, 2017).

382 The Monterey Bay Aquarium Seafood Watch created a free smartphone app that allows users to find nearby restaurants and stores that serve sustainably fished seafood. The Seafood Watch App, MONTEREY BAY AQUARIUM, https:/perma.cc/ZYD6-K2Y8 (last visited Feb. 25, 2017).

383 The Eat Well Guide provides a free, online, searchable directory of "over 25,000 handpicked restaurants, farms, markets and other sources of local, sustainable food throughout the US." About Eat Well Guide, EAT WELL GUIDE, https://perma.cc/6LCJ-AZ2Q (last visited Feb. 25, 2017). 
More generally, the power of social media to promote a sustainable future has just begun to emerge. The posting of daily air quality assessments in Beijing based on a trusted pollution monitoring station on the roof of the United States Embassy shapes everyday behavior and choices for millions of Chinese citizens-and has helped to create growing pressure for improved air quality in China. ${ }^{384}$ Likewise, just as Waze collects, aggregates, and displays real-time traffic data from thousands of cars and has transformed driving practices for many drivers-great potential exists for crowd-sourced environmental data to provide dramatically improved foundations for sustainability choices in many circumstances. ${ }^{385}$

\section{F. Nongovernmental Organizations and other Partnerships}

The importance of partnerships goes beyond the shift of some traditional governmental functions to nongovernmental entities, such as open-space conservation by land trusts. ${ }^{386}$ Like-minded individuals may decide to band together to take up issues and promote activities that governments might historically have done-but are not now doing or are doing inadequately. For example, the Breakthrough Energy Coalition, organized by Bill Gates and a dozen other billionaires and launched at the 2015 Paris Climate Change negotiations, has plans to mobilize at least $\$ 2$ billion in support of clean energy technology development. ${ }^{387}$

Many environmental NGOs have also come to recognize that their 20th century focus on trying to shape government regulations was too narrow. They are therefore updating their "business models." A number of groups now seek to make a direct difference on critical environmental problemsrather than lobbying for government regulation. The Nature Conservancy (TNC), for example, pioneered new conservation finance techniques that protect land and wildlife while still generating returns on their investment that can go toward conserving additional land. ${ }^{388}$ The World Wildlife Fund's (WWF) investments in parks, rangers, and protected area management in Asia and Africa to protect endangered species-including elephants, rhinos,

384 See Joby Warrick, U.S. Embassies are Going to Measure Other Countries' Air Quality. Surprise: Some Don't Like It Much, WASH. POST (Feb. 19, 2015), https://perma.cc/43DT-5VEB (noting that "the daily reports from the embassy's monitor added to the pressure that eventually led China to take dramatic steps to reduce smog").

385 Beijing officials, for example, are using data from social media for air pollution forecasting for the city. Federico Guerrini, How Bejjing is Using Data from Social Media and IoT to Boost Air Pollution Forecasting, FoRBES (May 21, 2016), https://perma.cc/9655-F9A8.

386 See Laura A. Johnson, An Open Field: Emerging Opportunities for a Global Private Land Conservation Movement 4-5 (Lincoln Inst. of Land Policy Working Paper No. WP14LJ1, Mar. 2014), https://perma.cc/BJA2-8T7U (documenting the rapid growth of land trusts starting in the 1980s).

387 Alex Nussbaum et al., Bill Gates Leads Billionaires in $\$ 2$ Billion Climate Investment, BLOOMBERG (Nov. 30, 2015), https://perma.cc/L7SV-6VDK.

388 The Nature Conservancy, About NatureVest, NATUREVEST, https://perma.cc/UP9J-TTF3 (last visited Feb. 25, 2017). 
and tigers-is another case in point. ${ }^{399}$ And the American Prairie Reserve, a nonprofit formed in 2004, has recently developed an innovative conservation model that uses strategic purchases of private property to connect existing public lands, thereby reducing habitat fragmentation in the Great Plains. ${ }^{300}$ Even individuals have started taking the lead in building new public-private partnerships in environmental protection. American philanthropist Greg Carr, for instance, has played a pivotal role in revitalizing the Gorongosa National Park in Mozambique ${ }^{231}$ and the late Douglas Tompkins funded significant conservation efforts in Patagonia. ${ }^{392}$

Environmental groups have also launched partnerships with businesses, hoping to guide them toward more sustainable practices. The Environmental Defense Fund's (EDF) work with Walmart represents a particularly notable investment in such a collaboration ${ }^{393}$ But TNC, ${ }^{394} \mathrm{WWF},{ }^{395}$ and even long-time litigation oriented National Resource Defense Council $(\mathrm{NRDC})^{396}$ have launched programs to work directly with the business community on sustainability issues. Other partnerships that promise to make a difference include those among companies such as the World Business Council for Sustainable Development, which has launched industry-specific sustainability projects that aim to bring together corporate thought leaders and develop best practices on specific issues. ${ }^{397}$ The Global Environmental Management Initiative, ${ }^{398}$ the Corporate Eco Forum, ${ }^{399}$ and We

389 See, e.g., Back a Ranger, WORLD WILDLFE FUND, https://perma.cc/2NS8-Z89P (last visited Feb. 25, 2017) (describing how "WWF"s Back a Ranger project helps rangers get the equipment, training, resources and infrastructure they need to stop wildlife crime"); see also Russell $E$. Train Education For Nature, WORLD WILDLIFE FUND, https://perma.cc/4546-N87L (last visited Feb. 25, 2017) (" [T] he Russell E. Train Education for Nature Program (EFN) has been providing financial support to proven and potential conservation leaders in Africa, Asia, and Latin America to gain the skills and knowledge they need to address the conservation challenges in their home countries.").

390 Building the Reserve, AM. PRAIRIE RESERve, https://perma.cc/C6SL-XUMA (last visited Feb. 25, 2017).

391 Gorongosa: Reviving a Park and a People, GloBAl ENV'T FACILTY (Oct. 11, 2016), https://perma.cc/2QNN-A45F.

392 Rachel Abrams \& Ashley Southall, Douglas Tompkins, 72, North Face Founder, Dies in Kayaking Accident, N.Y. TIMES, Dec. 9, 2015, at B14.

393 See Diane Regas, Walmart, EDF and 3 Reasons to Think Bigger on Collaboration, GREENBIZ (Mar. 10, 2016), https://perma.cc/B6V6-A36Q.

394 Corporate Partnerships: Xcel Energy, NATURE CONSERVANCY, https://perma.cc/85XRW2WB (last visited Feb. 25, 2017) (describing the Nature Conservancy's partnership with Xcel Energy to preserve prairie land).

395 Partnerships: Coca-Cola, WORLD WILDLIFE FUND, https://perma.cc/SR95-M25L (last visited Feb. 25, 2017) (describing WWF's partnership with Coca-Cola to protect freshwater resources).

396 Peter Lehner, Partnership, Persuasion, and the NRDC's Work with Georgia Pacific, GREENBIZ (Nov. 24, 2010), https:/perma.cc/JLX5-VJZD (describing NRDC's negotiations with timber purchaser Georgia Pacific).

397 See About Us: Overview, WORLD BUS. COUNCIL FOR SUSTAINABLE DEv., https://perma.ce/ S3Q2-Z2ZW (last visited Feb. 25, 2017).

398 Global ENVTL. MGMT. InITIATIVE, https:/perma.cc/TQ6D-DNGJ (last visited Feb. 25, 2017).

399 CORP. ECO F., https://perma.cc/H47W-6MU6 (last visited Feb. 25, 2017). 
Mean Business ${ }^{400}$ are other examples of this sort of business-to-business partnership. Simply put, today's sustainability "ecosystem" is much broader and deeper than the federal government-led pollution control regulatory regime of the $1970 \mathrm{~s}-\mathrm{a}$ fact that should be celebrated as we reimagine environmental protection in the 21 st century.

\section{G. Focus on Finance}

Perhaps the single biggest weakness in the 20th century model of environmental protection was the lack of focus on where the money necessary for pollution control and other investments would come from. ${ }^{401}$ But this shortcoming has now been identified-and ideas abound for funding the range of investments required for a sustainable future. ${ }^{402}$ From Green Banks to "green bonds" to sustainability-minded investment funds, new institutions and financial mechanisms are being developed at many scales to encourage the flow of resources to companies, technologies, infrastructure projects, and research efforts that seek to address sustainability challenges. ${ }^{403}$

The 20th century approach to clean energy relied upon the federal government "picking winners" and subsidizing selected companies, technologies, and, sometimes, whole industries. ${ }^{404}$ Even though the government's track record is not as bad as critics would suggest, ${ }^{405}$ change

400 WE MEAN BUS. CoALITION, https:/perma.cc/N6FK-K3V2 (last visited Feb. 25, 2017).

401 Richard B. Stewart, Benedict Kingsbury \& Bryce Rudyk, Climate Finance: Key Concepts and Ways Forward 1 (N.Y. Univ. Pub. Law \& Legal Theory, Working Paper No. 164, Dec. 1, 2009), https:/perma.cc/GR9R-H42Y (" Climate finance is fundamental to curbing anthropogenic climate change. . climate finance issues have received only limited and belated attention.").

402 Id. at 2-7 (summarizing a variety of regulatory and governance strategies for scaling up climate finance by 2050). See generally SCHMIDHEINY \& ZORRAQUIN, supra note 357 (discussing the role financial actors can play in sustainable development).

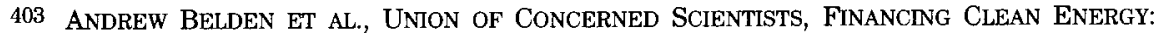
Cost-EFFective ToOls For State Compliance wITH THE Clean POWER PLAN 2-3 (2015) (touting the benefits of state green banks and state green bonds); CURTIS S. PROBST, EARTH INST., PRIVATE Sector Financing and PUBlic-Private Partnerships for Financing Clean Energy 2, 3, 7,9 11, 13-14 (2014) (reviewing a variety of private-only and public-private funding models, including solar asset securitization, on-bill programs, and several guarantee structures); Christopher Kaminker \& Fiona Stewart, The Role of Institutional Investors in Financing Clean Energy 6 (Org. for Econ. Co-operation \& Dev., Working Paper on Finance, Insurance and Private Pensions No. 23, 2012) (noting that institutional investors, including pension funds and insurance companies, have "an important role to play" in closing the clean energy gap); FELIX MORMaNN \& DAN REICHER, BROOKINGS INST., SMARTER FINANCE FOR ClEANER ENERgY: OPEN UP

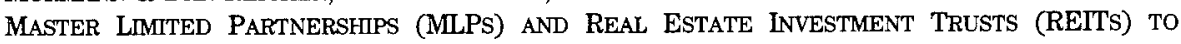
RENEWABLE ENERGY INVESTMENT 3-4 (2012) (proposing to expand MLPs and REITs-two wellestablished investment vehicles-to renewable energy investment).

404 Albert C. Lin, Lessons from the Past for Assessing Energy Technologies for the Future, 61 UCLA L. REV. 1814, 1842 (2014). For example, the United States government selected corn ethanol as a "winner" and has been supporting the technology since the 1970s. Id. at 1826-27; see also Adler, supra note 343, at 23 (noting that "most government-supported scientific research comes in the form of research grants").

405 See Hilary Kao, Beyond Solyndra: Examining the Department of Energy's Loan Guarantee Program, 37 WM. \& MARY ENVTL. L. \& POL'Y REV. 425, 506 (2013) (arguing that loan 
has not occurred at the pace and scale required. ${ }^{406}$ Among other problems, the public sector has a hard time playing the role of venture capitalist (VC). While VC firms can thrive if one or two out of ten investments pay off in a big way, governments cannot afford such a low batting average. ${ }^{407}$ The failures get too much attention and the successes too little. Everyone knows that the United States Department of Energy (DOE) lost \$535 million on Solyndra, ${ }^{408}$ but who can name a company that DOE funding helped launch? In fact, DOE support has helped dozens of clean energy ventures get going. ${ }^{409}$ But we now need a different model of government support for the transition to a sustainable energy future.

The 21st century clean energy strategy needs to focus on using limited public funds to leverage private capital. Such an approach ensures that the

guarantees "can serve as a useful credit enhancement tool to support the [renewable energy industry]"); Sabrina T. Howell, Financial Constraints as Barriers to Innovation: Evidence from R\&D Grants to Energy Start Ups 1-2, 37 (Jan. 7, 2015) (unpublished manuscript), https://perma. cc/6FYV-ARLC (finding that DOE's Small Business Innovation Research grant program increased the likelihood that firm would later receive venture capital funding, as well as increased patent production).

406 There exists a large and well-established literature on innovation policy. See generally Daniel J. Hemel \& Lisa Larrimore Ouellette, Beyond the Patents-Prizes Debate, 92 TEX. L. REV. 303 (2013) (surveying the literature on the effectiveness of different innovation policy instruments, including patents, prizes, research and development tax credits, and federal research grants). And a growing body of work has begun to apply these insights within the energy-environment context. See generally Kenneth Gillingham \& James Sweeney, Market Failure and the Structure of Externalities, in HARNESSING RENEWABLE ENERGY IN ELECTRICAL Power Systems: Theory, Practice, Policy 69 (Boaz Moselle et al. eds., 2010); Bronwyn H. Hall \& Christian Helmers, The Role of Patent Protection in (Clean/Green) Technology Transfer, 26 SANTA CLARA HIGH TECH. L.J. 487 (2010) (examining the role of the patent rewards system for climate-change technology innovation and diffusion); Adam B. Jaffe, Richard G. Newell \& Robert N. Stavins, A Tale of Two Market Failures: Technology and Environmental Policy, 54 ECOLOGICAL ECON. 164 (2005) (arguing that addressing the market failures associated with the production of clean energy technologies is critical to addressing climate change); Richard G. Newell, International Climate Technology Strategies, in POST-KYOTO INTERNATIONAL ClimATE POLICY: IMPLEMENTING ARCHITECTURES FOR AGREEMENT 403 (Joseph E. Aldy \& Richard N. Stavins eds., 2010) (discussing how intellectual property rights-and alternative innovation policy instruments-can be used to spur green innovation); Reichman, Rai, Newell \& Wiener, supra note 344 (same); Zachary Liscow \& Quentin Karpilow, Innovation and Climate Law 14 (unpublished manuscript) (Mar. 8, 2017), https:/perma.cc/DR3G-SZV9 (arguing that the path dependent nature of innovation justifies government subsidization of clean energy technologies, even in the presence of an optimal Pigouvian tax on carbon).

407 Leonard, supra note 344, at 202 (arguing that "high-risk investments are not necessarily a good use of public funds, but they are apt for venture capital enterprises because they bring the potential of high returns").

408 For an exhaustive analysis of Solyndra, see Kao, supra note 405, at 475-91; see also Matthew L. Wald, Solar Firm Aided by U.S. Shuts Doors, N.Y. TIMES, Sept. 1, 2011, at B1.

409 See Jeff Brady, After Solyndra Loss, U.S. Energy Loan Program Turning a Profit, NAT'L PuB. RADIO (Nov. 13, 2014), https://perma.cc/5CL4-XEMW; Justin Doom, U.S. Expects \$5 Billion from Program that Funded Solyndra, BLoOMBERG (Nov. 12, 2014), https://perma.cc/ZZ99-SG54 (noting that positive returns to the DOE renewable-nergy loan program "contradict[s] the widely held view that the U.S. has wasted taxpayer money funding failures including Solyndra"). Some prominent success stories include Tesla Motors, Agua Caliente (a utility scale solar project), and Antelope Valley (a utility scale solar project). David Biello, Obama Has Done More for Clean Energy Than You Think, SCI. AM. (Sept. 8, 2015), https://perma.cc/5NFC-GPHA. 
discipline of private investors in picking projects will overcome any government tendency to place politically expedient "bets," such as on cornbased ethanol in the face of the quadrennial Iowa caucuses that play an outsized role in our Presidential selection process. ${ }^{410}$ Rather, money should flow based on the promise of marketplace success. Using a "leverage" strategy would also help take the investments in energy efficiency, renewable power, and reconfigured electricity infrastructure to a scale the government cannot achieve on its own. ${ }^{411}$

De-risking can take many forms. ${ }^{412}$ A range of incentives and strategies to steer private capital toward clean energy projects are emerging in many places and at many scales. ${ }^{413}$ Connecticut, for instance, launched a Green Bank in 2011 to extend the reach of its limited clean energy funds. ${ }^{414}$ The Connecticut Green Bank developed multiple strategies for leveraging private capital including reverse auctions combined with power purchase agreements to create a portfolio of "financeable" renewable energy projects. ${ }^{415}$ Likewise, Connecticut's breakthrough Property Assessed Clean Energy loan program for commercial buildings (C-PACE) has greatly expanded the pool of private capital available for energy efficiency retrofits at low interest rates by creating a mechanism that links the energy loans

410 Thomas Pyle, The Iowa Caucuses Have a Winner: Ethanol, WALL STREET J., Mar. 26, 2015, at A17 (describing how "special-interest groups ... leverage the outsize influence of the Iowa presidential caucuses to pressure 2016 hopefuls into supporting the [Renewable Fuel Standard]").

411 Sujata Gupta et al., Cross-Cutting Investment and Finance Issues, in INTERGOVERNMENTAL Panel on Climate Change, Climate Change 2014: Mrtigation of Climate Change 1207, 121011 (O. Edenhofer et al. eds., 2014) (estimating that, between 2010 and 2029, global investments in low-emission generation technologies will need to increase by $\$ 360$ billion per year and energy-efficiency spending on building, industry, and transportation sectors will need to increase by $\$ 336$ billion in order to limit warming to 2 degrees Celsius).

412 Esty, Regulatory Transformation, supra note 110, at 409; Kevin Rosner, Incentive Mechanisms for Public-Private Investment in Renewable Energy Projects in Frontier Economies 6 fig.1 (Stockholm Env't Inst., Technical Report No. 2016-01, 2016), https:/perma.cc/WZB9-Q72J (identifying a broad range of public finance instruments that can reduce investment risk, including concessional loans, partial credit guarantees, and mezzanine capital); Bethany Speer, Residential Solar Photovoltaics: Comparison of Financing Benefits, Innovations, and Options, at v (Nat'l Renewable Energy Lab., Technical Report No. NREL/TP6A20-51644, 2012), https:/perma.cc/N2X5-PL5B (discussing how state and local governments can help finance rooftop solar installations through credit-enhanced revolving loans); Green Bank 101, COALITION FOR GREEN CAP., https://perma.cc/5R7C-5PRU (last visited Feb. 25, 2017) (discussing a variety of mechanisms by which green banks have been able to "use limited public resources to leverage greater private investment in clean energy," including credit enhancement, co-investment, warehousing and securitization, property assessed clean energy financing, and on-bill financing).

413 Leonard, supra note 344, at 198-200.

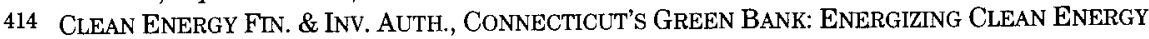
FINANCE 1 (2013).

415 Between 2011 and 2013 alone, the Connecticut Green Bank invested more than $\$ 220$ million into renewable energy infrastructure and achieved an impressive leverage ratio of roughly $\$ 10$ of private-sector capital for every taxpayer dollar. Id. 
repayments to local property taxes, greatly diminishing the risk of default. ${ }^{416}$ The Green Bank has also induced banks to fund expanded clean energy deployment with a commitment to a loan loss reserve that limits the exposure of the private capital providers. ${ }^{417}$

Beyond financing, the Connecticut Green Bank also developed a set of standardized forms and contracts to reduce the "soft costs" of doing clean energy projects such as the time and expense of getting building permits, organizing inspections, and meeting other regulatory requirements. ${ }^{418}$ Faster approvals and lower costs translate into less risk for the banker and lower interest rates for the homeowner or business undertaking a clean energy project. At the same time, green banks can facilitate the flow of private capital toward clean energy through warehousing and securitization. ${ }^{419}$ Many potential clean energy loans will be too small for private lenders to costeffectively underwrite. ${ }^{420}$ Green banks, however, can store and aggregate these smaller loans into large portfolios that can then be sold to large private investors in the secondary market. ${ }^{421}$

Limited government funds therefore need to be focused on: 1) leveraging private capital, 2) shifting investment decisions on the margins toward more (rather than less) sustainable projects, and 3) supporting those at the low end of the income spectrum. ${ }^{422}$ These principles hold at the local, state, national, and global levels. As the portfolio of activities of the Connecticut Green Bank discussed above makes clear, some governments have already recognized this new imperative. ${ }^{423}$ At the national scale, the

416 Leonard, supra note 344 , at 213. In the past three years, C-PACE has successfully financed $\$ 86$ million of green energy upgrades. CONN. GREEN BANK, PACESETTERS QUARTERLY DASHBOARD (2016), https://perma.cc/ZF9N-KDS9.

417 Under the Smart-E Loan program, Connecticut homeowners can finance energy upgrades using long-term, low-interest Smart-E Loans. These loans are provided by local lenders, who-in turn-benefit from loan-loss reserves from the Connecticut Green Bank. CLEAN ENERGY Fin. \& INV. AUTH., supra note 414, at 4 (2013).

418 See Leonard, supra note 344 , at 215-16.

419 Coal. for Green Capital, supra note 412.

420 Id. (noting that "small and geographically disperse projects like residential or small business energy efficiency projects ... [are] relatively expensive to underwrite for a bank and not worth the trouble).

421 Id. Through warehousing and securitization, for example, the Connecticut Green Bank was able to attract $\$ 100$ million from investor Hannon Armstrong to the C-PACE program. See Quentin Karpilow, Connecticut's C-PACE Program Is Picking Up Speed, ClEAN EnERgy Fin. F. (Mar. 30, 2016), https://perma.cc/5HP3-2AR5.

422 The Clean Energy Incentive Program (CEIP) is a good example of policy incorporating equity concerns. The CEIP is a voluntary component of President Obama's Clean Power Plan that incentivizes states to invest in clean energy and energy efficiency resources prior to the official rollout of the Clean Power Plan. Clean Energy Incentive Program Design Details, 81 Fed. Reg. 42,940, 42,942 (proposed June 30, 2016) (to be codified at 40 C.F.R. pts. 60, 62). Importantly, however, project receive additional credits (i.e., bonuses) for developing energy efficiency projects in disadvantaged communities. See id. at 42,943.

423 Other states-including New York, California, and Rhode Island-have followed Connecticut's lead and established their own state green banks. Current Green Banks, COALITION FOR GREEN CAP., https://perma.cc/GCS3-WF6G (last visited Feb. 25, 2017). Outside of the United States, Australia, the United Kingdom, and Japan have also developed green investment banks. Id. 
work of DOE has begun to evolve in this direction, ${ }^{424}$ but more could be done to extend the reach of the inevitably limited government funds available to support clean energy. At the global scale, too much emphasis was placed in the past on government funding under the development assistance grant model. ${ }^{425}$ But change is coming. The Global Environmental Facility has long emphasized funding the incremental cost of making development projects sustainable. Perhaps the time has come-as a recent Center for Global Development report suggests ${ }^{426}$-for the World Bank and the other multilateral development banks to be rechartered to focus funding the sustainability dimension of the development projects they support.

Likewise, the new Green Climate Fund, which was launched with the old government-funding model in mind, has begun to shift gears toward a 21st century approach to sustainability finance. In a recent "Climate Finance Architecture and the Green Climate Fund" technical note, some of the Fund's key officials call for more focus on addressing "climate finance gaps" and using concessional finance to cover the "incremental costs" of clean energy projects. ${ }^{427}$ They envision a sharpened focus for the Fund as a "riskbearing vehicle to leverage private investment" and a mechanism for sending "market signals" in support of the flow of capital toward clean energy and climate change solutions. ${ }^{428}$

While these initial steps are promising, much more needs to be done to build out the structure of green lights needed to promote the vast investment flows required to finance a sustainable future. To provide just one example: the flow of funds into green bonds has grown from $\$ 2.6$ billion in 2012 to $\$ 41.8$ billion in $2015 .{ }^{429}$ But are the projects receiving these funds really helping to deliver a more sustainable future? While a set of "green bond principles" has been developed by market participants, there are no established mechanisms for evaluating or certifying that particular projects are green ${ }^{430}$ Under this new model of sustainability, government could play a critical role in developing and promoting such mechanisms.

424 U.S. Dep't of Energy, Energy Investment Partnerships, ENERGY.Gov, https://perma.cc/ J4KD-FR9D (last visited Feb. 25, 2017).

425 See generally Sanjay Kumar, Green Climate Fund Faces Slew of Criticism, 527 NATURE 419 (2015) (summarizing criticisms of the Green Climate Fund).

426 Ctr. For Glob. Dev., Multilateral Development Banking for This Century's DEVELOPMENT ChaLLENGES: FTVE RECOMMENDATIONS to SHAREHOLDERS OF THE OLD AND NEW MULTLLATERAL DEVELOPMENT BANKS 14-15 (2016), https://perma. cc/4JGF-46XG.

427 Daniel C. Esty, Climate Finance Architecture and the Green Climate Fund: Technical Note 3 (May 2015) (unpublished manuscript) (on file with author).

428 Id.

429 Climate Bonds InTtative, 2015 Green Bond Market RounduP (2015), https://perma.cc/4SCG-22ZZ.

430 Org. For Econ. Co-operation \&. Dev., Green Bonds: Mobilising the Debt CaptTal MARKETS FOR A LOW-CARBON TRANSITION 1 (2015), https://perma.cc/6YLH-UQZ4 (noting that one major barrier to the growth of the green bond market is "a lack of a commonly accepted green standards and definitions"). For one attempt to standardize green bonds, see INT'L CAPTTAL MKT. Assoc., THE GREEN BOND PRINCIPLES (2016), https://perma.cc/A5RK-FZ99. 


\section{H. Economic Transition and Slower Growth}

While the Digital Age has transformed many sectors of society, the United States (and the industrialized world more generally) has seen the rate of economic growth decline over recent decades. ${ }^{431}$ Moreover, while the unemployment rate has come down since the Great Recession of 2008-2009, there remains a sense of economic insecurity for large segments of the middle class. ${ }^{432}$ Slow productivity growth and the prospect of a less vibrant future economy adds to an ongoing perception of economic distress ${ }^{433}$ and the imperative for a transformed approach to environmental protection.

Expanded investments in environmental protection have always been easier to "sell" to the public during good times. ${ }^{434}$ And the pressure to reduce regulatory burdens expands during economic hard times. ${ }^{435}$ While the call by some to abolish the EPA can be dismissed as overwrought, ${ }^{436}$ the urgency of regulatory reform to ensure ongoing public support for environmental

431 Robert J. Gordon, The Rise and Fall of American Growth: The U.S. STANDard of LIVING SINCE the CIVIL WAR 522-31 (2016); Thomas PiketTy, Capital IN THE Twenty First CENTURY 97 fig.2.3 (Arthur Goldhammer trans., 2014); see also William Galston, The New Challenge to Market Democracies: The Political and Social Costs of Economic Stagnation, BROOKINGS INST. (Oct. 20, 2014), https://perma.cc/GC7S-PCSF (indicating that "[t]he Great Recession shattered complacent assumptions on both sides of the Atlantic" ${ }^{n}$.

432 Patricia Cohen, Middle Class, or So They Think, N.Y. TimES, Apr. 11, 2015, at B1; see also Jeffrey D. Sachs, Opinion, Economic Choices Facing the United States: Why We Need a New Direction, Bos. GLOBE (Sept. 12, 2016), https://perma.cc/6JEW-YBF8 ("The reasons for the pessimism are real. The United States is experiencing the lowest growth rates in the postwar era. Economic growth recorded since the 2008 financial crisis has been about half of what was forecast in mid-2009: 1.4 percent annual growth during 2009-2015 compared with a project rate of 2.7 percent. Around 81 percent of American households, according to a recent McKinsey study, experienced flat or falling incomes between 2005 and 2014.”)

433 Lawrence H. Summers, The Age of Secular Stagnation: What It Is and What to Do About It, Foreign AFF., Mar./Apr. 2016, at 2, 4; see also Ronald Brownstein, America's Persistent Economic Gloom, ATLANTIC (Jan. 27, 2016), https://perma.cc/NR9Z-TW5G (noting the disconnect between American's outlook on the U.S. economy and indicators of economic performance); Jeffrey D. Sachs, Opinion, The GDP Doesn't Tell the Whole Story About Economic Growth, Bos. GLOBE (Feb. 4, 2016), https://perma cc/5USP-TGNT (noting that several economists argue the economically prosperous period from 1920-1970 was a "golden age never to be revisited").

434 Research has found a positive relationship between the GDP-per-capita and public support for environmental regulation and spending. See DEBORAH LYNN GUBER, THE GRASSROOTS OF A GREen Revolution: POLLING AMERICA ON THE ENVIRONMENT 67 (2003) (finding negative correlations between the unemployment rate and public support for environmental spending); Euel Elliott et al., Political and Economic Determinants of Individuals Support for Environmental Spending, 51 J. ENVTL. MGMT. 15 (1997) (linking macroeconomic conditions to individuals' support for environmental spending).

435 Clem Brooks \& Jeff Manza, A Broken Public? Americans' Responses to the Great Recession, 78 AM. Soc. REv. 727, 729 (2013) (finding that public demand for new government policy declined during the Great Recession); Lyle Scruggs \& Salil Benegal, Declining Public Concern about Climate Change: Can We Blame the Great Recession?, 22 GLOB. ENvTL. ChANGE 505,505 (2012) (attributing the recent decline in the American public's concern about climate change to the Great Recession).

436 See, e.g., Ben Adler, Why is Trump So Fixated on Abolishing the EPA?, GRIST (May 20, 2016), https://perma.cc/XP5X-C9V2 (noting that EPA implements most environmental statutes and without it, "the result would be total incoherence"). 
protection programs is real. And the limits on governmental capacity to fund new energy and environmental program adds to the logic for a transformed approach to sustainability.

The decline in the America's economic circumstances has not only made environmental politics more difficult, it has also generated persistent government budget crises at the federal, state, and local levels. ${ }^{437}$ With limited growth in revenues and spiking entitlement costs (particularly related to health care), governments have been forced to make significant cuts in other programs, including environmental agencies. ${ }^{438}$ A new regulatory model that achieves more with less therefore has a fiscal logic as well as a political one. As noted earlier, there exists an array of egovernment tools that can enhance regulatory efficiency and support the broader governmental roles called for in this Article. ${ }^{439}$ But investments in bringing new technologies into government will have to be made despite tight budget circumstances.

\section{Planetary Boundaries}

After thousands of years during which the human footprint on the planet was relatively small, we now live in a world where the scale of human impacts is large relative to the resource base and assimilative capacity of the planet. The work of Rockström and his colleagues to map the "planetary boundaries" that human activity is bumping up against has sharpened the focus of the scientific community on the critical limits-including acidification of the ocean, thinning of the Earth's ozone layer, and the buildup of greenhouse gases in the atmosphere. ${ }^{440}$ The limits identified are

437 Tracy Gordon, State and Local Budgets and the Great Recession, BrookInGS INST. (Dec. 31, 2012), https://perma.cc/5KPY-EB8N ("More than in past economic downturns, state and local governments were a prominent casualty of the recent recession.").

438 See, e.g., WORLD WILDLIFE FUND ET AL., GREEN INVESTMENTS: How BUdGet CUTS ARE IMPACTING OUR COMMUNITIES AND THE ENVIRONMENT: THE CASE FOR REINVESTMENT IN FY17 (2016), https://perma.cc/43DP-9NVW (documenting declines in spending across a wide array of federal environmental agencies and programs); Judy Benson, Impact of DEEP Budget Cuts Outlined for State Lawmakers, DAY (New London, Conn.) (July 18, 2016), https://perma.cc/S486RRQ7 (documenting how Connecticut's Department of Energy and Environmental Protection will respond to a $14 \%$ reduction in its budget from 2015 to 2016); Beth Daley \& Caitlin Bawn, The Budget Cuts Disarming the Environmental Fight in Massachusetts, HuFfington Post (May 24, 2016), https://perma.cc/92BC-FD7H (documenting declines in Massachusetts' environmental budget since 2001); Dennis Pillion, Alabama's Environmental Management Funding Slashed in 2016 Budget; Fee Increases Loom, AL.COM (Sept. 18, 2015), https://perma.cc/AY6W-WY6F (discussing Alabama state environmental agency budget cuts); Joe Wertz, State Budget Agreement Brings Sharp Funding Cuts to Agencies Overseeing Oklahoma's Environment, NAT'L PUB. RaDIO: STATEIMPACT (May 26, 2016), https://perma.cc/D796-HGKQ (discussing Oklahoma state environmental agency budget cuts); Candy Woodall, Gov. Wolf's DEP Chief Leading Agency Through High Cuts, Low Times, PENNLrve (Dec. 30, 2015), https://perma.cc/K4FK-KMNB (documenting Pennsylvania state environmental agency budget cuts).

439 See discussion supra Part V.A.2.

440 Johan Rockström et al., A Safe Operating Space for Humanity, 461 NATURE 472, 472 (2009) (planetary boundaries "define the safe operating space for humanity with respect to the Earth system and are associated with the planet's biophysical subsystems or processes... [w]e 
not as fixed as some would argue, but the principle remains important: while nature is generally robust, human activity affects—and could overwhelmEarth's capacity to sustain life.

Fundamentally, the work on planetary boundaries reminds us that we need to pay attention to both the scale of human impacts on the natural world and their time dimension. Problems of great scope and long duration-such as climate change driven by greenhouse gas emissions that blanket the Earth and persist for centuries-are particularly hard to manage. ${ }^{441}$ The costs of reducing the harm are concentrated on those taking action now while the benefits are diffuse-spread over both space and time. ${ }^{42}$

We are living in what is now described as the Anthropocene-a new epoch in which human activity is the dominant force shaping nature and defining the contours of life on Earth. ${ }^{43}$ This reality argues for a more disciplined and systematic approach to environmental law and policy-and makes more urgent the need to refresh the legal framework and the incentives it provides. The reality of planetary boundaries argues for policy approaches that provide ways to address systematically problems that are hard to perceive either because they are diffuse across the globe or spread over time. ${ }^{444}$ In this regard, carefully structured data tracking and metrics that spotlight environmental problems-especially invisible ones or those with "long tails" that only emerge over decades-will be critical ${ }^{455}$ Likewise, environmental experts, who can use cutting-edge scientific tools and data analytics to spot trends, highlight environmental degradation, and assess policy interventions will be essential-cooperating and competing across

have found nine such processes for which we believe it is necessary to define planetary boundaries: climate change; rate of biodiversity loss (terrestrial and marine); interference with the nitrogen and phosphorus cycles; stratospheric ozone depletion; ocean acidification; global freshwater use; change in land use; chemical pollution; and atmospheric aerosol loading."). See generally Rockstrom ET AL., BIG WORID SMALL Planet: ABUNdance WITHIN Planetary BOUNDARIES (Peter Miller ed., 2015); Jeffrey D. Sachs, Dir., Earth Inst., International Growth Centre Public Lecture: The Age of Sustainable Development, (Feb. 4, 2015) (recording and slides available at https://perma.cc/SB57-VVA8).

441 Kelly Levine et al., supra note 16, at 124 (classifying climate change as a "super wicked" problems due to its free riding incentives and long-term time horizons).

442 See Lazarus, Super Wicked Problems, supra note 47 at 1157 ("Climate change legislation is peculiarly vulnerable to being unraveled over time for a variety of reasons, but especially because of the extent to which it imposes costs on the short term for the realization of benefits many decades and sometimes centuries later.").

443 See Paul J. Crutzen, Geology of Mankind, 415 NATURE 23, 23 (2002). For discussions of this work, see Will Steffen et al., The Anthropocene: Conceptual and Historical Perspectives, 369 PHIL. TRansactions RoYal Soc'y A 842, 843-44 (2011). For further discussion of this topic, SEe JEDEDIAH PURDY, AFTER NATURE: A POLITICS FOR THE ANTHROPOCENE (2015).

444 LAZARUS, supra note 10 , at 221-25 (discussing the spatial and temporal challenges of climate change).

445 WAGNER \& WEITZMAN, supra note 203, at 48-79 (arguing that society may be underestimating the expected costs of climate change by failing to adequately account for the likelihood that global warming outcomes follow a "fat tail" distribution). 
traditional boundaries (government, NGO, and academic) and scales (local, state, national, and global) ${ }^{448}$

\section{CONCLUSION}

As a result of the political rupture, structural failure, and implementation shortcomings described in Part II above, we have ended up with environmental policy stasis. This gridlock has meant that legislators and policymakers settle for "small ball" initiatives that produce modest and often temporary gains. ${ }^{47}$ Under these conditions, real reform and systemic policy transformation cannot be advanced. The environmental arena has become what Professor Steven Teles calls a "kludgeocracy," where "'[c]lumsy but temporarily effective'" policy fixes continually add complexity and opaqueness to our governance processes ${ }^{448}$ As one patch gets placed upon another without any systematic clean-up or any overarching reform strategy, regulatory frameworks become more difficult to comply with. And the incentives created by patchwork policies tend to serve the needs of rentseeking special interests in ways that are often hidden from public view. The complexity of the system makes government agencies not just slow and heavy but also inefficient and ineffective.

As Teles notes, kludgeocracy serves neither the needs of conservatives nor progressives. ${ }^{49}$ It hides the size and scope of government activities from the citizenry, to the detriment of those who want a smaller and more focused public sector. By making government seem bureaucratic, opaque, and incompetent, it adds to the burden of those who want to make the case for public goods delivered by a robust public sector-as is critical in the environmental arena. Thus, the status quo gets locked in with only the most modest of incremental changes getting made. ${ }^{450}$

446 An example of this type of collaboration is the "Green Horizon," a partnership between Beijing and IBM to better monitor the city's air pollution levels. Press Release, Int'l Bus. Machines Corp., IBM Expands Green Horizons Initiative Globally to Address Pressing Environmental and Pollution Challenges (Dec. 9, 2015), https://perma.cc/3Y2Y-PMSR. Specifically, IBM is "harnessing the processing power of 'big data' as well as the 'internet of things,' weather modeling, and supercomputing" to provide Beijing with more accurate air pollution data and projections. Gwynn Guilford, How IBM is Using Big Data to Fix Beijing's Pollution Crisis, QUARTZ (July 6, 2014), https://perma.cc/PCQ4-SYP9.

447 The reauthorization of Toxic Substances Control Act might be seen as an exception to this rule. See Frank R. Lautenberg Chemical Safety for the 21st Century Act, Pub. L. No. 114-182, 130 Stat. 448 (2016); Passing a Strong New Law, ENVTL. DEF. Fund https://perma.cc/7CJ3-MY73 (last visited Feb. 25, 2017).

448 Steven M. Teles, Kludgeocracy in America, 17 NAT'L AFF., Fall 2013, at 97, 98.

449 Id. at 101-02.

460 Of course, incremental changes can lay the foundations for more ambitious reform. Jonas Meckling et al., Winning Coalitions for Climate Policy, 349 SCIENCE 1170, 1170 (2015) (arguing that renewable energy subsidies can support the growth of clean energy coalitions, which, in turn, demand more stringent climate policies, such as a carbon charge); Eric Biber, Cultivating a Green Political Landscape: Lessons for Climate Change Policy from the Defeat of California's Proposition 23, 66 VAND. L. REv. 399, 402 (2013) (arguing that "incrementalism can be a successful strategy for climate change policy" if it can build up climate friendly interest 
But there is no need for the environmental realm to remain one of pitched battle. There are many opportunities-as the transformations discussed in Part V make clear-to advance new and better approaches to residual problems, and to bring fresh thinking and innovation tools and policies to bear on both long-standing issues and new challenges.

The price being paid every day by every American for the environmental status quo has become too high. As a nation, we cannot afford to continue to adopt little fixes and ignore the structural problems with our environmental regime. We need real reform, and a commitment to innovation as a core policy virtue. We need to celebrate the 20 th century pollution control framework that is now in place and build upon what has worked over the past fifty years. At the same time, we must be willing to admit that our present environmental regulatory regime is not functioning optimally, and that further transformation of our policy framework is now required to meet changed circumstances and needs.

Thomas Jefferson argued that a "little rebellion now and then is a good thing, and ... a medicine necessary for the sound health of government." This Article seeks to revive a Jeffersonian spirit of rebellion and advance a call for systematic rethinking and reform of the fundamental structure of America's environmental protection strategy. In proposing to recast our environmental laws and policies for the 21st century, I recognize that change is always difficult to bring about-and transformative change is even more challenging. But there is a path forward and a political logic that can be constructed for both Democrats and Republicans to walk together toward a better environmental future.

groups). However, such a trajectory is not guaranteed and may result in large inefficiencies if government support becomes influenced by rent-seeking interest groups.

451 Letter from Thomas Jefferson to James Madison (Jan. 30, 1787), in 11 THE PAPERS OF THOMAS JEFFERSON 92, 93 (Julian P. Boyd ed., 1955). 